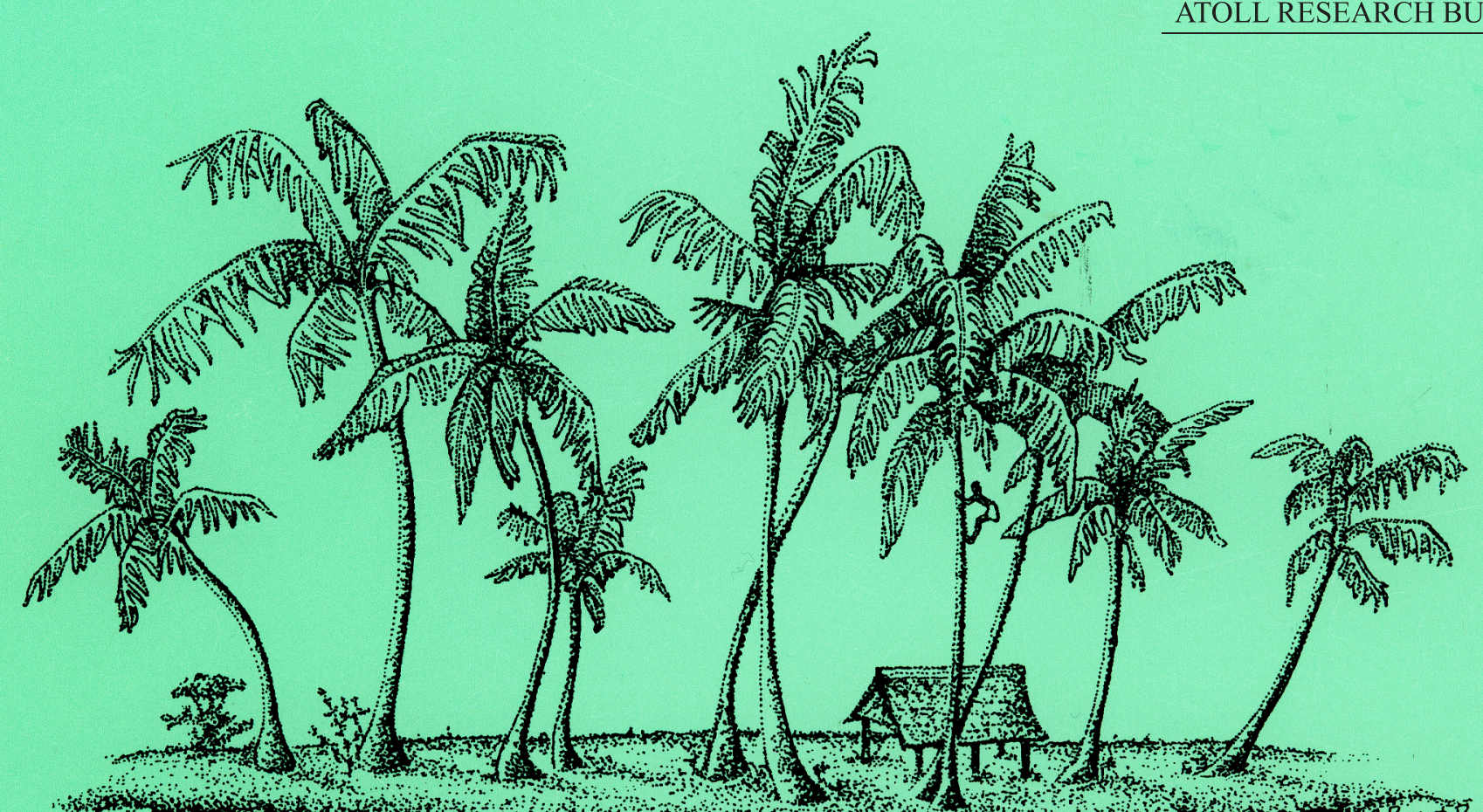

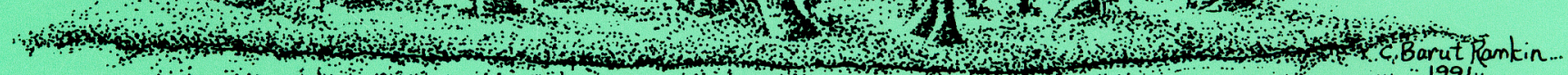
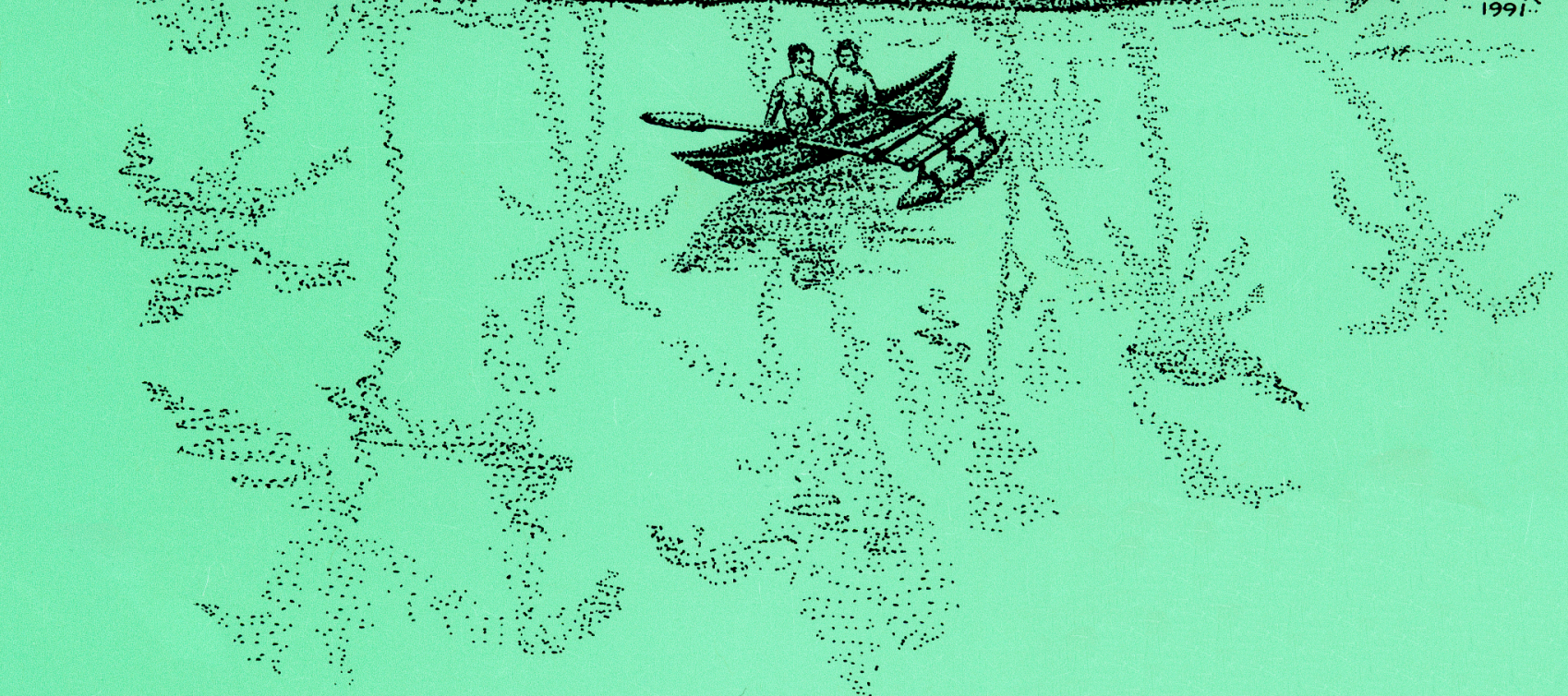

FLORA OF KIRITIMATI (CHRISTMAS) ATOLL, NORTHERN LINE ISLANDS, REPUBLIC OF KIRIBATI

R. R. Thaman and Alan Tye 


\section{FLORA OF KIRITIMATI (CHRISTMAS) ATOLL, NORTHERN LINE ISLANDS, REPUBLIC OF KIRIBATI}

R. R. Thaman and Alan Tye

Atoll Research Bulletin No. 608 25 November 2015

Smithsonian Institution Scholarly Press

Washington, D.C. 
All statements made in papers published in the Atoll Research Bulletin are the sole responsibility of the authors and do not necessarily represent the views of the Smithsonian Institution or of the editors of the bulletin. Articles submitted for publication in the Atoll Research Bulletin should be original papers and must be made available by authors for open access publication. Manuscripts should be consistent with the "Author Formatting Guidelines for Publication in the Atoll Research Bulletin." All submissions to the bulletin are peer reviewed and, after revision, are evaluated prior to acceptance and publication through the publisher's open access portal, Open SI (http://opensi.si.edu).

Published by SMITHSONIAN INSTITUTION SCHOLARLY PRESS

P.O. Box 37012, MRC 957

Washington, D.C. 20013-7012

www.scholarlypress.si.edu

The rights to all text and images in this publication are owned by either the contributing authors or third parties. Fair use of materials is permitted for personal, educational, or noncommercial purposes. Users must cite author and source of content, must not alter or modify the content, and must comply with all other terms or restrictions that may be applicable. Users are responsible for securing permission from a rights holder for any other use.

ISSN: 0077-5630 (online) 


\section{CONTENTS}

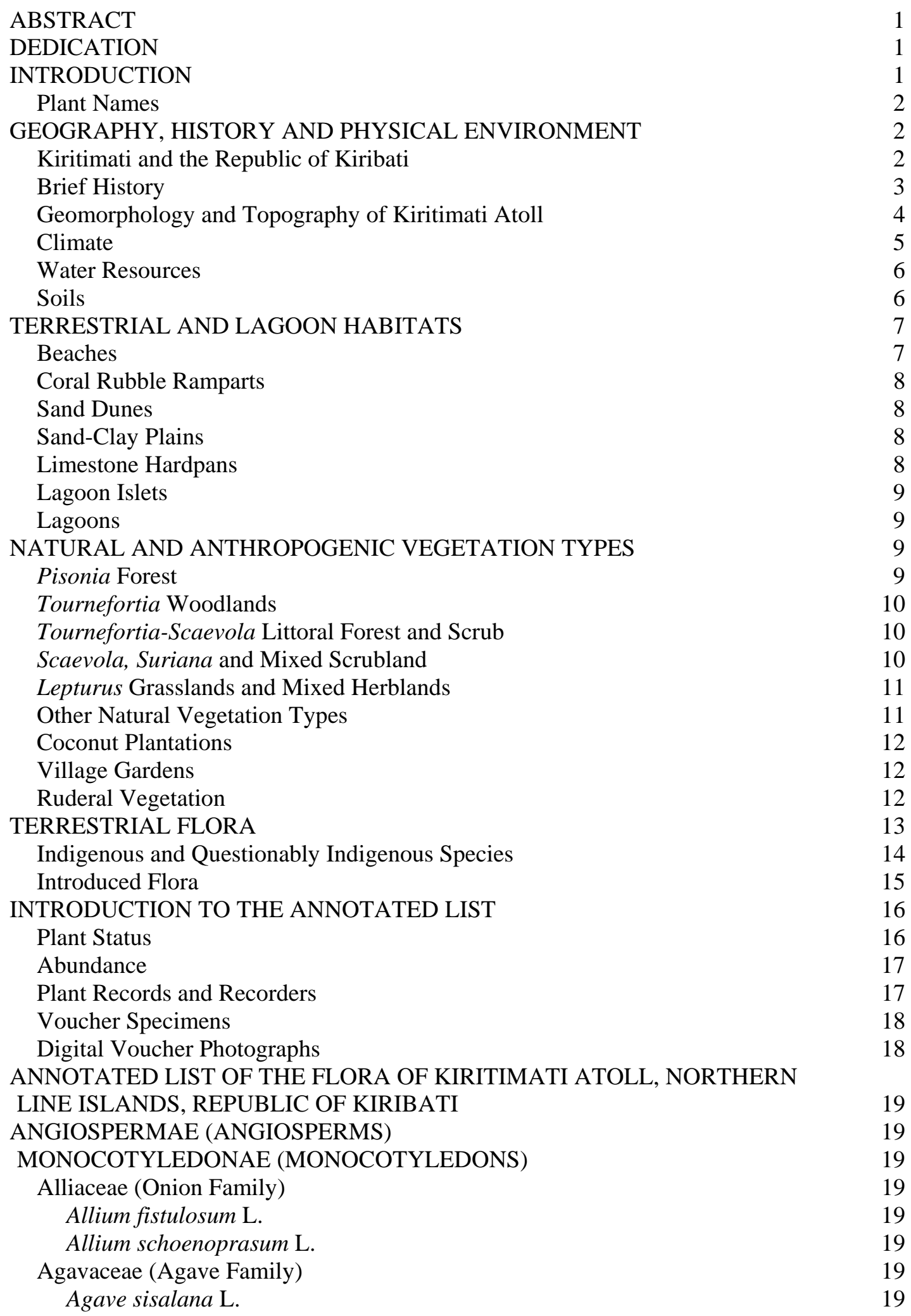


$\begin{array}{lr}\text { Amaryllidaceae (Amaryllis Family) } & 19\end{array}$

Crinum asiaticum L. 19

Crinum xanthophyllum Hannibal 20

Hymenocallis littoralis (Jacq.) Salisb. $\quad 20$

Zephyranthes rosea (Lindl.) Green 20

Araceae (Arum Family) 20

$\begin{array}{ll}\text { Colocasia esculenta (L.) Schott } & 20\end{array}$

Cyrtosperma chamissonis (Schott) Merr. 21

Xanthosoma sagittifolium (L.) Schott 21

Arecaceae (Palm Family) 21

Cocos nucifera L. $\quad 21$

Phoenix sylvestris var. robusta $\quad 22$

Pritchardia pacifica Seem. \& Wendl.

Asparagaceae (Asparagus Family) 22

Cordyline fruticosa (L.) A. Chev.

Asphodelaceae (Asphodel Family) 22

Aloe vera (L.) Burm. f.

Commelinaceae (Dayflower or Spiderwort Family) 23

$\begin{array}{ll}\text { Tradescantia spathacea Swartz } & 23\end{array}$

Cyperaceae (Sedge Family) 23

Cyperus compressus L. 23

Cyperus rotundus L. 23

Fimbristylis cymosa R. Br.

Kyllinga nemoralis (Forst.) Dandy ex Hutchinson and Dalziel 24

Mariscus javanicus (Houtt.) Merr. $\quad 24$

Pycreus polystachyos (Rottb.) P. Baeuv. 24

Musaceae (Banana Family)

Musa (AAB Group)

Musa (ABB Group) 25

Musa undetermined cultivars $\quad 25$

Pandanaceae (Pandanus Family) 26

Pandanus tectorius Park. $\quad 26$

Poaceae (Grass Family) $\quad 26$

Cenchrus ciliaris L. $\quad 26$

Cenchrus echinatus L. $\quad 26$

$\begin{array}{ll}\text { Chloris barbata (L.) Sw. } & 27\end{array}$

$\begin{array}{ll}\text { Dactyloctenium aegyptium (L.) Beauv. } & 27\end{array}$

$\begin{array}{ll}\text { Digitaria stenotaphrodes (Nees ex Stued.) Stapf. } & 27\end{array}$

$\begin{array}{ll}\text { Eleusine indica (L.) Gaertn. } & 28\end{array}$

$\begin{array}{ll}\text { Eragrostis ciliaris (L.) R. Br. } & 28\end{array}$

Eragrostis paupera Jedwabn. 28

Eragrostis scabriflora Swallen 28

Eragrostis tenella (L.) Beauv. ex Roem. \& Schult. 29

Eustachys petraea (Sw.) Desv. $\quad 29$

Lepturus repens (G. Forst.) R. Br. $\quad 29$

Melinis repens (Willd.) Zizka 30

Panicum maximum Jacq. $\quad 30$

Saccharum officinarum L. $\quad 30$

Zea mays L. $\quad 30$

DICOTYLEDONAE (DICOTYLEDONS) 31

Acanthaceae (Acanthus Family) 31 
$\begin{array}{ll}\text { Pseuderanthemum carruthersii (Seem.) Guill. } & 31\end{array}$

Pseuderanthemum carruthersii (Seem.) Guill. var. carruthersii 31

Pseuderanthemum carruthersii (Seem.) Guill. var. atropurpureum (Bull) Fosb. 31

Pseuderanthemum reticulatum (Bull) Radlk. 31

Aizoaceae (Carpetweed or Iceplant Family) 32

Sesuvium portulacastrum L. var. griseum Deg. \& Fosb. 32

Amaranthaceae (Amaranth Family) 32

Amaranthus dubius Mart. ex Thell. 32

Amaranthus tricolor L.

Anacardiaceae (Cashew or Rhus Family) 33

Mangifera indica L. 33

Annonaceae (Custard Apple Family) 33

Annona cf. squamosa L. 33

Apocynaceae (Dog-Bane Family) 33

Catharanthus roseus (L.) G. Don 33

Nerium oleander L. 33

Plumeria obtusa L. $\quad 34$

Plumeria rubra L. $\quad 34$

Araliaceae (Panax Family) 34

Polyscias filicifolia (C. Moore) L.H. Bailey 34

Polyscias fruticosa (L.) Harms 34

Polyscias guilfoylei (Cogn. and March.) Bailey 34

Polyscias scutellaria (N.L. Burman) Fosberg $\quad 35$

Asclepiadiaceae (Milkweed Family) $\quad 35$

$\begin{array}{ll}\text { Cryptostegia madagascariensis Bojer } & 35\end{array}$

Asteraceae (Aster or Composite Family) 35

Bidens pilosa L.

Chromolaena odorata (L.) King and Robinson. 35

Cosmos sulphureus Cav. 36

Cyanthillium cinereum (L.) H. Rob 36

Gaillardia x grandiflora 36

Helianthus annuus L. $\quad 36$

Lactuca sativa L. $\quad 36$

Pluchea carolinensis (Jacq.) G. Don 36

Pluchea x fosbergii Cooperider \& Galang $\quad 37$

$\begin{array}{ll}\text { Pluchea indica (L.) Less. } & 37\end{array}$

Sonchus oleraceus L. 38

Tagetes erecta L. 38

Tridax procumbens L. 38

Verbesina encelioides (Cav.) B. \& H ex Gray 38

Zinnia violacea Cav. 38

Barringtoniaceae (Barringtonia Family) 39

Barringtonia asiatica (L.) Kurz 39

Bignoniaceae (Bignonia Family) 39

Spathodea campanulata Beauv. 39

Tecoma stans ( L.) Juss. ex HBK. 39

Boraginaceae (Heliotrope or Borage Family) 39

Cordia sebestena L. 39

Cordia subcordata Lam. 39

Heliotropium anomalum Hook. \& Arnott 40

Heliotropium procumbens Mill. 40 
Tournefortia argentea L. f. $\quad 41$

Brassicaceae (Cabbage or Mustard Family) 41

Brassica chinensis L. var. chinensis $\quad 41$

Brassica x hybridus "Saladeer” 42

Brassica oleracea L. var. capitata L. 42

Lepidium bidentatum Mont. 42

Raphanus sativus L. var. longipinnatus Bailey 42

Caricaceae (Pawpaw Family) 42

Carica papaya L. 42

Casuarinaceae (Casuarina Family) 43

Casuarina equisetifolia L 43

Clusiaceae (Mangosteen Family) 43

Calophyllum inophyllum L. 43

Combretaceae (Terminalia Family) 44

Terminalia catappa L. 44

Terminalia samoensis Rech.

Convolvulaceae (Morning-Glory Family) 44

Ipomoea batatas (L.) Lam. 44

Ipomoea macrantha R. \& S. 44

Ipomoea pes-caprae (L.) Sweet 45

Cucurbitaceae (Melon Family) 45

Citrullus lanatus (Thunb.) Matsum. and Tan. 45

Cucumis melo L. 45

Cucumis sativus L. 45

Cucurbita moschata Duchesne ex Poir. 46

Lagenaria siceraria L. 46

Momordica charantia L. 46

Cuscutaceae (Cuscuta Family) 46

Cuscuta campestris Yuncker 46

Euphorbiaceae (Spurge Family) $\quad 47$

Acalypha amentacea Roxb. ssp. wilkesiana (Müll. Arg.) Fosberg 47

Chamaesyce hirta (L.) Millsp. $\quad 47$

Chamaesyce hypericifolia (L.) Millsp. $\quad 47$

$\begin{array}{ll}\text { Chamaesyce prostrata (Ait.) Small } & 47\end{array}$

Chamaesyce thymifolia (L.) Millsp. $\quad 48$

Cnidoscolus chayamansa McVaugh $\quad 48$

Codiaeum variegatum (L.) Bl. 48

Euphorbia cyathophora Murr. 48

Euphorbia pulcherrima 49

Euphorbia tirucalli L. $\quad 49$

Manihot esculenta Crantz 49

Pedilanthus tithymaloides (L.) Poit. $\quad 49$

Phyllanthus amarus Sch. \& Th. 49

Fabaceae (Pea Family) 50

Bauhinia malabarica Roxb. $\quad 50$

Delonix regia (Boger ex Hook.) Raf. 50

$\begin{array}{ll}\text { Erythrina variegata var. orientalis (L.) Merr. } & 50\end{array}$

Leucaena leucocephala (Lam.) de Wit 50

Macroptilium atropurpureum (DC.) Urb. $\quad 51$

Macroptilium lathyroides (L.) Urb. $\quad 51$

Phaseolus vulgaris L. $\quad 51$ 
Senna occidentalis (L.) Link 51

Sophora tomentosa L.

Vigna marina (J. Burm.) Merr.

Goodeniaceae (Naupaka Family) 52

Scaevola taccada (Gaertn.) Roxb. 52

Lamiaceae (Mint Family) 53

Ocimum tenuiflorum L.

Lauraceae (Laurel Family) 53

Cassytha filiformis L. 53

Malvaceae (Mallow Family) 53

Abelmoschus esculentus (L.) Moench 53

Abelmoschus manihot (L.) Moench $\quad 54$

Abutilon indicum (L.) Sweet ssp. albescens (Miq.) Borssum-Waalkes 54

Hibiscus rosa-sinensis L. $\quad 54$

Hibiscus tiliaceus L.

Sida fallax Walp.

Sida rhombifolia L.

Moraceae (Mulberry Family)

Artocarpus altilis (Park.) Fosb.

Artocarpus altilis x mariannensis $\quad 56$

Artocarpus mariannensis Trec. 56

Ficus carica L. $\quad 56$

Ficus tinctoria Forst. f. $\quad 56$

$\begin{array}{ll}\text { Moringaceae (Moringa Family) } & 57\end{array}$

Moringa oleifera Lam.

Nyctaginaceae (Four-O'Clock Family) 57

Boerhavia albiflora Fosb.

Boerhavia repens L. 58

Boerhavia tetrandra Forst. $\quad 58$

Bougainvillea x buttiana Holttum \& Standley 58

Mirabilis jalapa L. $\quad 59$

Pisonia grandis R. Br. $\quad 59$

Passifloraceae (Passion Flower Family) $\quad 59$

$\begin{array}{ll}\text { Passiflora foetida L. } & 59\end{array}$

Polygonaceae (Buckwheat Family) $\quad 60$

$\begin{array}{ll}\text { Coccoloba uvifera (L.) L. } & 60\end{array}$

$\begin{array}{ll}\text { Portulacaceae (Purslane Family) } & 60\end{array}$

$\begin{array}{ll}\text { Portulaca lutea Solander ex Forst. f. } & 60\end{array}$

Portulaca oleracea L. $\quad 60$

Rubiaceae (Coffee Family) $\quad 61$

Gardenia taitensis DC. $\quad 61$

Guettarda speciosa L. $\quad 61$

Hedyotis romanzoffiensis (C \& S.) Fosb. 61

Ixora casei Hance 62

Morinda citrifolia L. $\quad 62$

Oldenlandia corymbosa L. $\quad 62$

Spermacoce assurgens Ruiz \& Pavón $\quad 62$

Rutaceae (Rue Family) 63

$\begin{array}{ll}\text { Citrus aurantiifolia (Christm.) Swingle } & 63\end{array}$

Solanaceae (Nightshade Family) 63

Capsicum annuum L. vars. 63 
Capsicum annuum L. var. grossum (L.) Sendtn. $\quad 63$

Capsicum frutescens L.

Nicotiana tabacum L.

Physalis angulata L.

Solanum lycopersicum L.

Solanum melongena L.

Sterculiaceae (Cocoa Family) $\quad 65$

Waltheria indica L.

$\begin{array}{ll}\text { Surianaceae (Suriana Family) } & 65\end{array}$

Suriana maritima L. $\quad 65$

Tiliaceae (Linden Family) 65

Triumfetta procumbens Forst. f. 65

Turneraceae (Turnera Family) 66

Turnera ulmifolia L. $\quad 66$

Verbenaceae (Verbena Family) 66

Clerodendrum inerme L. 66

Lantana camara L. $\quad 66$

$\begin{array}{ll}\text { Premna serratifolia L. } & 67\end{array}$

Zygophyllaceae (Caltrop Family) 67

$\begin{array}{ll}\text { Tribulus cistoides L. } & 67\end{array}$

ACKNOWLEDGMENTS 68

APPENDIX: PLANT RECORDERS AND COLLECTORS ON KIRITIMATI ATOLL 69

REFERENCES 


\title{
FLORA OF KIRITIMATI (CHRISTMAS) ATOLL, NORTHERN LINE ISLANDS, REPUBLIC OF KIRIBATI
}

\author{
R. R. THAMAN ${ }^{*}$ and ALAN TYE ${ }^{2}$
}

\begin{abstract}
This paper is a compilation and analysis of all vascular plants that have been reported on Kiritimati (Christmas) Atoll in the Northern Line Islands of the Republic of Kiribati. It is based on field inventories conducted by the authors on six field visits to the atoll between 1996 and 2012 plus available published and unpublished records of vascular plant collections and observations made on the atoll. The total number of vascular plant species that have been recorded at some time on Kiritimati, including all indigenous and introduced species (whether in cultivation or not) is 168, plus three hybrids and three additional varieties, making a total of 174 taxa. Of these, three records are doubtful, leaving a reliably reported total of 171 taxa in 166 species. Only 10 of the reported taxa were not seen by one or other of us in the period 1996-2012, and of these at least six have probably died out on the island, leaving an extant flora of around 165 reliably recorded taxa (including the hybrids and varieties) in 160 species. There have been no ferns or gymnosperms recorded on the island. Probably only 15 (9\%) or perhaps up to 19 of the reliably reported species are native, and most of the present-day flora is made up of deliberate or unintentional introductions made since the date of European discovery of the atoll. Of these, at least 54 and perhaps up to 59 species have naturalized.
\end{abstract}

\section{DEDICATION}

This paper is dedicated to the current and past generations of people who have lived on Kiritimati Atoll and who depend on the conservation, sustainable use and enrichment of their life-giving plants and animals and their local knowledge, as a basis for their continued habitation of this unique and beautiful but challenging island environment.

\section{INTRODUCTION}

This paper is a compilation and analysis of all vascular plants that have been reported on Kiritimati (Christmas) Atoll in the Northern Line Islands of the Republic of Kiribati. It is based on field inventories conducted by the authors on six field visits to the atoll between 1996 and 2012 plus available published and unpublished records of vascular plant collections and observations made on the atoll. Most of the earlier published records were reviewed by Wester (1985), along with a compilation of species that he collected and observed during a one-week visit in August 1982 (see Table 2 for the details of previous collectors). R. R. Thaman (RRT) visited the island for two one-week periods in 1996 and 2006, during which he attempted to inventory all vascular plants present on the island, including weeds and cultivated species, and after which he completed a working annotated record of the flora, including local I-Kiribati names and ethnobotanical information. This record was verified, updated and augmented by Alan Tye

\footnotetext{
${ }^{1}$ Emeritus Professor of Pacific Islands Biogeography, The University of the South Pacific (USP), Suva, Fiji Islands. Thaman_r@usp.ac.fj *Corresponding author.

${ }^{2}$ Invasive Species Advisor, Secretariat of the Pacific Environment Programme (SPREP), Apia, Samoa. Present address: PO Box 31, Kalo Chorio Oreinis, Nicosia 2616, Cyprus. alantye@gmail.com
} 
(AT), based on four visits to the island, totaling five weeks from 2008 to 2012, when he paid particular attention to native and naturalized introduced species. AT also carried out a new review of the Kiritimati literature and examination of Kiritimati specimens at BISH, particularly those representing unique or unusual species records, including those not found by either of us.

We first present relevant background information on the geography, history and physical environment of Kiritimati Atoll, the main terrestrial and nearshore lagoon habitats, the major vegetation types and the terrestrial flora. This is followed by an annotated systematic listing of all vascular plant taxa reported at some time from Kiritimati.

\section{Plant Names}

Throughout this article, plants are referred to by their scientific names, sometimes shortening them to genus alone (if only one species in the genus is known from Kiritimati). At first mention in a given section and in the annotated list of all plants that have been reported present on Kiritimati, or where we consider it useful for potential readers, including I-Kiribati (the people of Kiribati), we add the both English and Kiribati language names (te taetae ni Kiribati), where known, using the following convention: English name (in regular type), Kiribati name (in bold), and scientific name (in italics), for example, bay cedar te araoua Suriana maritima. All three names (where known) of every plant are given in its account in the annotated list, in which, when known, a brief translation of the Kiribati names is provided in parentheses, for example, te roti ("rose"). The Kiribati language names follow the current spelling system used in Kiribati, with " $t$ " followed by an "i" (as in the word Kiritimati) pronounced like an "s," and with " $t$ " followed followed by a "u" also pronounced like an "s," as in the northern Gilbert Islands.

\section{GEOGRAPHY, HISTORY AND PHYSICAL ENVIRONMENT}

\section{Kiritimati and the Republic of Kiribati}

The Republic of Kiribati became an independent state in 1979, after being part of the British Gilbert and Ellice Islands Colony. Kiribati consists of 33 main islands in three groups, the Gilbert Islands (known locally as Tungaru) in the west, the Phoenix Islands in the center, and the Northern and Southern Line Islands to the east, plus the single island of Banaba, $400 \mathrm{~km}$ to the west of the Gilbert Islands (Figure 1). The islands are extremely isolated, with a total land area of only $823 \mathrm{~km}^{2}$ spread over an ocean area of some 13 million $\mathrm{km}^{2}$ between $4^{\circ} 43^{\prime} \mathrm{N}$ and $11^{\circ} 25^{\prime} \mathrm{S}$ latitude and $169^{\circ} 32^{\prime} \mathrm{W}$ and $150^{\circ} 14^{\prime} \mathrm{W}$ longitude. They extend some 3,870 km from Banaba in the west to the Southern Line Islands in the east and 2,050 km from Teraina (Washington Island) in the Northern Line Islands to Flint Island in the Southern Line Islands (Carter, 1984; Thaman et al., 1997).

Kiritimati Island is the southernmost of the Northern Line Islands, at about 2,500 km south of Honolulu, 2,700 km north of Tahiti and 3,300 km east of Tarawa, the country's capital island in the Gilbert Islands. The Line Islands consist of three inhabited islands in the north, Teraina (Washington), Tabuaeran (Fanning) and Kiritimati (Christmas), and five uninhabited southern islands, Malden, Starbuck, Vostok, Caroline and Flint. They have a total land area of $515.7 \mathrm{~km}^{2}$ and constitute $62.7 \%$ of the land area of Kiribati. A fourth island, the northernmost in the Line group, is Palmyra, which is not permanently inhabited and is a possession of the United States of America (Carter, 1984).

Kiritimati is considered to be the atoll with the greatest land area in the world. With a total area of $364 \mathrm{~km}^{2}$, it is the largest island in Kiribati, making up 44\% of the total land area of the country. It is the administrative center for the Line and Phoenix Islands and, along with Tarawa, is one of Kiribati's two ports of entry (Carter, 1984; Thaman et al., 1997). 


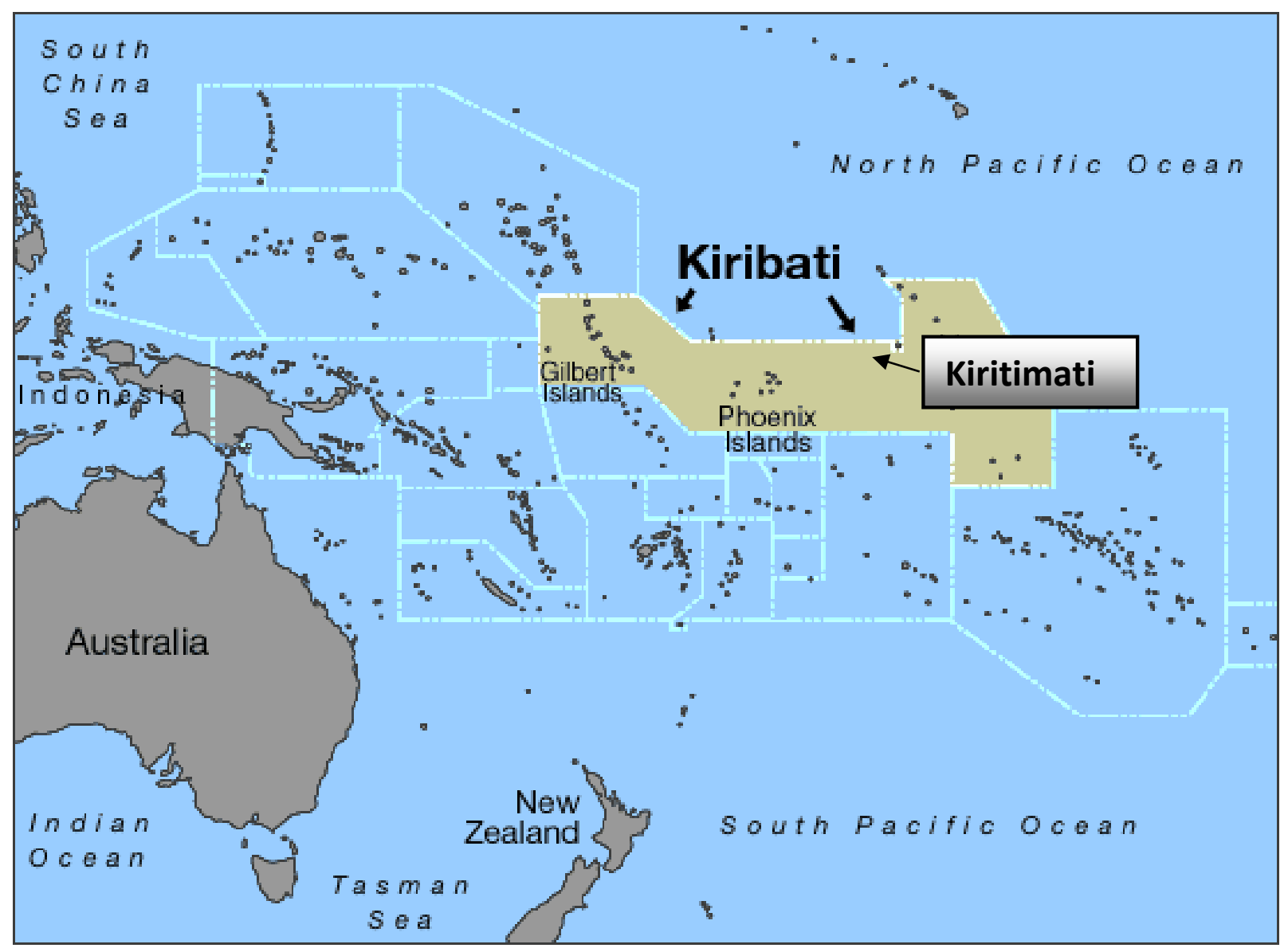

Figure 1. Map showing the locations of the Republic of Kiribati, the Gilbert, Phoenix and Line Islands, and Kiritimati Atoll. Adapted from a map from the Office of the President, Republic of Kiribati, http://www.climate.gov.ki/about-kiribati/.

\section{Brief History}

This brief account focuses on a few points of history of relevance to the development of the flora of Kiritimati; a more comprehensive historical review has been given by Perry (1981). At the time of European discovery by Hernando de Grijalva's Spanish expedition in 1537, and when Captain James Cook visited the island on 24 December 1777, Kiritimati was uninhabited, although there are remains of early temporary Polynesian settlement (Emory, 1934; Maude, 1968). Although subsequent contact was made with the island after Cook and there was sporadic phosphate mining on the islands after 1858, more or less permanent occupation of the island began in 1882 when large-scale coconut planting began. By 1886 some 18,000-20,000 coconut palms had been planted and 200 tons of pearl shell exploited. By the turn of the century, some 70,000 coconut palms had been planted, although only $25 \%$ survived due to prolonged drought (Jenkin and Foale, 1968). Kiritimati was uninhabited from 1905-1912 after which it, along with Washington and Fanning Islands, was run as a coconut plantation by Central Pacific Coconut Plantations Ltd. The Gilbert and Ellice Islands Company took over the management of the Christmas Island coconut plantations in 1941. It has been estimated that coconut plantation has replaced about onethird of the natural vegetation of the island and that the government coconut estate covered some 5,170 ha (Garnett, 1983; Teeb'aki, 1993).

During World War II the island was occupied by Allied troops, who constructed several airstrips, an extensive road network and other infrastructure. From 1956 to 1962, atmospheric nuclear bomb tests were conducted by the British and Americans off the island, during which time up to 4,000 servicemen were 
based there. Military interest ended in 1969 and, using the remaining infrastructure, including $100 \mathrm{~km}$ of sealed road, Kiritimati was established as the administrative center of the Line Islands (Wester, 1985; Teeb'aki, 1993). Since Kiribati independence in 1979, Kiritimati, with its extensive land area, became the focus for resettlement of people from Tarawa and other highly populated atolls of Kiribati. By 1989 the population was estimated at 2,000, most of whom lived in London, Banana and Poland villages in the west of the island (Teeb'aki, 1993). By 2010 the population was estimated to be about 5,791, compared to 5,115 and 3,431 in 2005 and 2000, respectively (Office of Te Beretitenti and T'Makei Affairs, 2012).

From the time of coconut plantation development, especially during military occupation and the development of the island as the administrative center and focus for resettlement, a range of exotic ornamentals, food plants and other plants, including weeds, have been deliberately or accidentally introduced to the island. For example, two species of Pluchea became widely dispersed throughout the island soon after World War II and now form dense stands in many areas, especially around the main settlements (Teeb'aki, 1992). There have also been a number of attempts, as part of resettlement efforts, to promote home food production and household vegetable gardening, and the island's Agricultural Station continues to import new species with potential for cultivation on the atoll (Teeb'aki, 1993; Thaman et al., 1997; AT, personal observation).

\section{Geomorphology and Topography of Kiritimati Atoll}

Although the common dictionary definition of atoll varies from a "ring-like coral island enclosing a lagoon" (Bryan, 1972) to "a circular coral reef or string of coral islands surrounding a lagoon" (Bryan, 1953; Wiens, 1962; Thaman 2008), these definitions are too simplistic because most groups of atolls, like the Gilbert Group of Kiribati, consist not only of "true atolls" with lagoons, but also of other small, lagoon-less, low-lying limestone islands, sometimes referred to as "table reefs." Similarly, the "true atolls" often, like Kiritimati, have multiple lagoons, ponds or basins separated by reefs, sand bars, islets or portions of the main island, and are often far from really circular (Thaman, 2008). Adapting the above definitions, the term "atoll" is here defined as a low-lying oceanic limestone reef island or group of islets, with or without lagoons, that has formed on a barrier reef, but which is not associated with a nearby high island or a continent. The term "islet" refers to the individual smaller islands or motu (a Polynesian name for reef islets) that are found on the reefs or in the lagoons of the main atoll island (Thaman, 2008).

Most of the islands of the Republic of Kiribati consist of atolls, including "true atolls" with reefs and low-lying islets with limited land areas that encircle or partially encircle central lagoons and small, lowlying limestone or reef islands with no lagoons. Kiritimati Atoll is, however, very different. It is slightly higher, much larger and has a distinct and more diverse environment compared with the other atolls of Kiribati. The large land area of Kiritimati, its relatively small main lagoon and abundance of smaller lagoons are caused at least in part by uplifting, of which evidence can be seen particularly in the center of the island, where there are extensive raised coral benches.

Most of Kiritimati's land area is composed of one continuous surface which, unbroken by passes or channels to the ocean, almost completely encircles a central tidal lagoon with an area of about $160 \mathrm{~km}^{2}$ (Figure 2). There is a large peninsula, Southeast Peninsula, and a double entrance or pass to the open ocean in the west of the island, in the middle of which lies Cook Island (Islet). South and east of the main lagoon, the surface is covered by countless landlocked hypersaline pools or lagoons, with a total area of about $168 \mathrm{~km}^{2}$, in a matrix of limestone hardpan (Thaman et al., 1997). The main tidal lagoon is connected by very small channels to Manulu and Ava Lagoons in the northeast. There are a number of islets within the main lagoon, the largest of which are Motu Tabu and Motu Upua (Thaman et al., 1997), and some of the larger land-locked lagoons, such as Isles Lagoon, contain many small islets.

All of the names of places on Kiritimati mentioned in this article, except specific sites within a given village (e.g. buildings, installations, streets, fields etc.), are shown on Figure 2. 


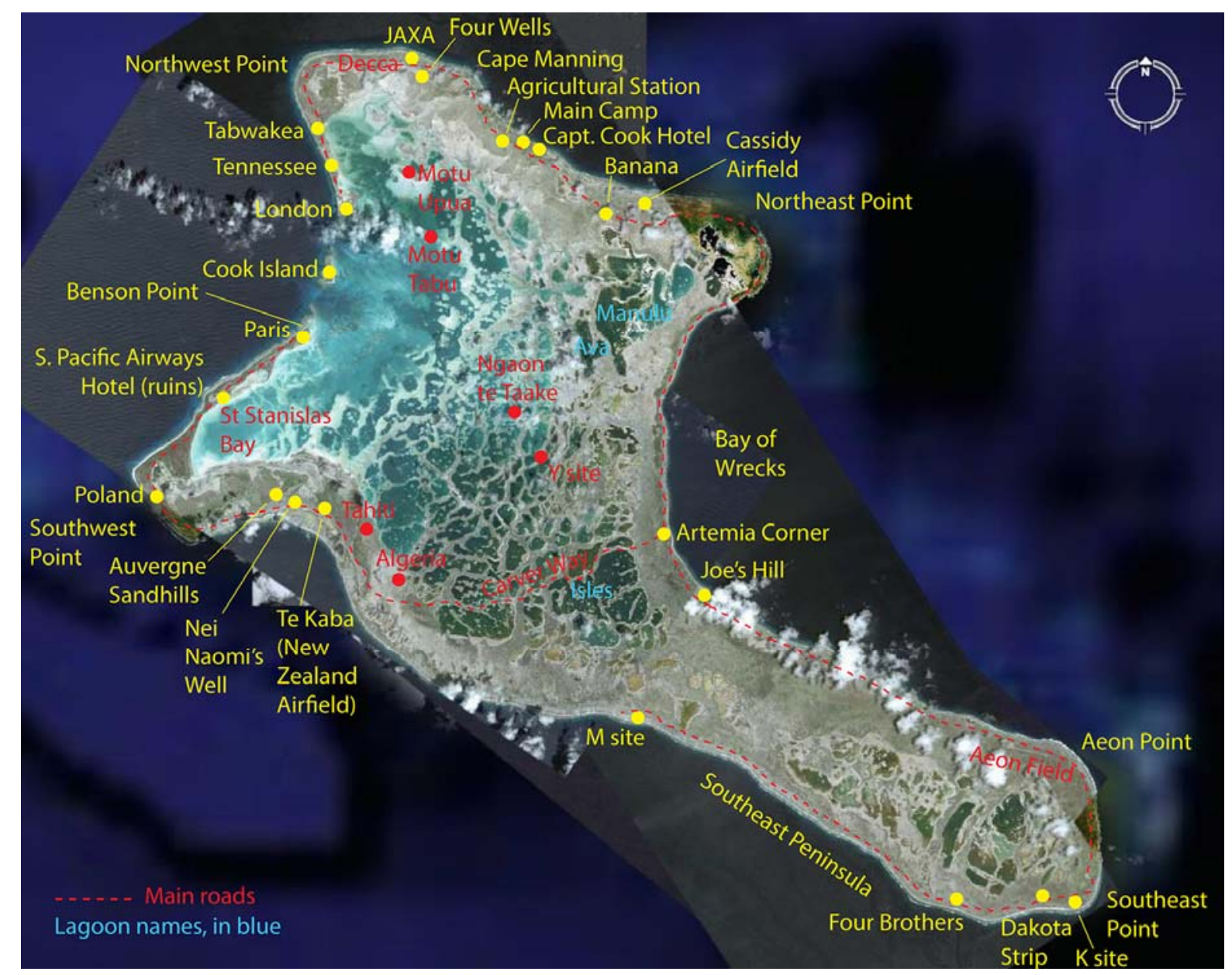

Figure 2. Kiritimati Atoll showing all localities mentioned in this article. Adapted from Google Earth. Image (C) 2015 DigitalGlobe.

\section{Climate}

Kiritimati is located in the dry equatorial oceanic climate zone and receives an average annual rainfall of only $766 \mathrm{~mm}$ (30.2 in). Compared to Tabuaeran and Teraina to the north, which have average annual rainfalls of 2,086 mm (82.1 in) and 2,902 mm (114.3 in) respectively, Kiritimati is extremely dry. Based on an average monthly rainfall for Kiritimati from 1951-1988, the wet season normally falls from January to July, with the driest months being August to December, and the highest rainfall normally occurring during April. However, the climate is heavily influenced by the El Niño Southern Oscillation (ENSO) cycle, with longer (mostly 2-6 years) drier periods separated by shorter (1-2 years) high rainfall periods associated with El Niño events (Falkland and White, 2007). Droughts during La Niña stages of the ENSO, such as that of 2005-2006, have a serious impact on the vegetation and the resident bird populations. In 2006, a high percentage of the Tournefortia trees on the smaller islets and in drier, more exposed sites and low-lying sites on the mainland were dead, as were areas of Suriana, but these still served as rookeries or perches for seabirds. Many of the coconut plantations, such as those near Poland, had a witches'-broom appearance, with skirts of dead fronds hanging down the trunks of the trees, and other areas that were formerly open Lepturus herbland looked more like salt flats, with either dead or dormant remnants of formerly healthy bunches of grass.

Average rainfall has increased in Kiritimati since the 1950s but the rainfall has become more variable: droughts have become less intense, of shorter duration and with a longer period between droughts 
(Falkland and White, 2007). Whether this change is part of a longer-term oscillation in climate cannot be determined from the relatively short rainfall record. However, such a cycle could see a return to drier conditions, as existed during the earlier part of the 20th century.

Kiritimati experiences fairly strong winds throughout most of the year, which cause an additional desiccating effect, and have contributed to the existence of sand dunes, including Joe's Hill (the highest elevation on the island at about $15 \mathrm{~m}$ above sea level), and coral rubble mounds with a relatively high elevation compared to other atolls (Thaman et al., 1997).

\section{Water Resources}

The only permanent freshwater resource on Kiritimati is groundwater in the form of "lenses" of often slightly brackish freshwater, hydrostatically "floating" on the higher density saltwater beneath the island. The height of a lens above sea level and the level of salinity vary in relation to the elevation and shape of islets and the amount of water use and rainfall. The major lenses are in the north of the island at Decca, Four Wells, Banana, and in the southwest at New Zealand Airfield; several minor lenses also occur (Falkland and White, 2007). Replenishment or recharge of the lenses is solely dependent on rainfall. In areas where the lens is close to the surface, pools are often found during excessively wet periods, especially during high tides (Thaman et al., 1997).

The location and characteristics of the groundwater influence the nature of the vegetation as well as the location of village wells and cultivation pits. The quantity and quality of groundwater and the habitability of atolls are severely affected during times of extended drought, particularly in areas where the lens is less well-developed.

Studies since the 1960s indicate that the freshwater lens could yield about $1800 \mathrm{~m}^{3}$ (1.8 million liters) per day if catchments could be cleared of trees (mostly coconuts) and shrubs, but this would reduce to around $1600 \mathrm{~m}^{3}$ per day if coconuts are not cleared (Falkland and White, 2007). At an estimated per capita consumption rate of 90 liters per day, this suggests that, based on water availability alone, Kiritimati could support a maximum of approximately 20,000 people. However, the mismatch between the location of lenses and population centers that could support expansion suggests that a more realistic figure should be approximately 13,500 people (Falkland and White, 2007).

\section{Soils}

The soils and substrate of Kiritimati are very infertile. They include young calcareous soils, sandy soils, limited areas of hydromorphic soils, highly alkaline hardpans, and very limited areas of phosphaterich, guano-derived soils under seabird rookeries. In general, the soils are young, shallow, alkaline, coarse-textured and have carbonatic mineralogy. Because of their immaturity, they vary little from the original coral limestone parent material. They are composed of a variable layer of organic matter and coral sand, foraminifera, fragments of shells and other marine organisms overlaying a limestone platform (Morrison, 1987).

Based on research elsewhere in Kiribati, potassium levels are often extremely low, and $\mathrm{pH}$ values of up to 8.2-8.9 and high $\mathrm{CaCO}_{3}$ levels make scarce trace elements, particularly iron (Fe), manganese (Mn), copper $(\mathrm{Cu})$ and zinc $(\mathrm{Zn})$, unavailable to plants. Activity of soil microorganisms is limited, soil waterholding capacity is very low because of coarse texture, and ground water is often saline. Fertility is highly dependent on organic matter to lower soil $\mathrm{pH}$, to capture and recycle plant nutrients, and to retain soil water in the excessively fast-draining soils. These factors together make conventional agriculture, as practiced on other larger Pacific islands, almost impossible on Kiritimati. They also preclude the existence of many common native coastal and introduced species that are common on other atolls and small low-lying islands (Morrison, 1987; Thaman et al., 1997.)

Although there is some organic matter in some areas of undisturbed soils in areas of higher water availability under natural vegetation, it can decrease dramatically as a result of clearance by fire or replacement by coconut plantations or other introduced plants. The unstable sandy areas of the island are 
likewise very nutrient deficient and, unless highly modified, only suitable for coconut cultivation and the planting or protection of indigenous coastal strand plants (Morrison, 1987; Thaman et al., 1997).

\section{TERRESTRIAL AND LAGOON HABITATS}

Terrestrial and lagoon habitats and major vegetation associations of ecological and economic importance on Kiritimati Island (adapted from Thaman et al., 1997) are:

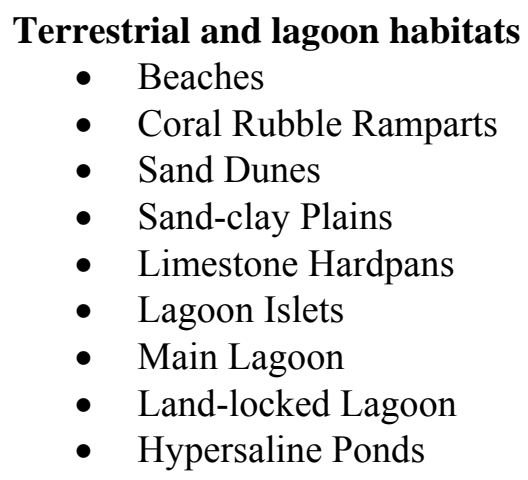

Vegetation associations

- Pisonia Forest

- Tournefortia woodlands

- Tournefortia-Scaevola Littoral Forests and Scrub

- Scaevola, Suriana and Mixed Scrublands

- Lepturus and Mixed Herblands

- Coconut Plantations

- Village and Houseyard Gardens

- Ruderal Vegetation

Although the terrestrial ecosystems, in most cases, directly correspond with different vegetation associations, the proximity and effects of the sea and lagoon ecosystems (e.g., the extensive network of hypersaline ponds, high waves and strong sea winds and associated salt spray) also contribute to the nature of the vegetation and flora of Kiritimati. Although some detail on plants is given under the individual habitats presented in this section, the main aspects of the vegetation are covered under the vegetation type and flora sections that follow.

\section{Beaches}

Kiritimati has many kilometers of unpolluted white-sand beaches that offer great potential for tourism development and serve as the interface between the terrestrial and marine ecosystems. Some of the main areas of extensive white-sand beaches include (1) the coastline from London extending north to Northwest Point and Cape Manning and along most of the north coast to Northeast Point; (2) the coast extending south from Joe's Hill, south of the Bay of Wrecks to Aeon Point; (3) the entire south coast from Southeast Point extending around Southwest Point to Benson Point on the west of the island; and (4) the lagoon-side of the island south of Benson Point and encircling reefs islets, such as Cook Island, Motu Upua and Motu Tabu (Thaman et al., 1997; Thaman and Tuxson 1997).

The beaches are commonly bordered on the seaward margin by limestone substrate in the intertidal zone and by Scaevola scrub or Scaevola-Tournefortia strand or littoral forest on the landward side. In some areas on the outer coast, and more commonly on beaches within the lagoon, the succulent Sesuvium 
portulacastrum is found in the outpost littoral vegetation. On the windblown flats along the shores of St. Stanislas Bay north of Nei Naomi's Well are scattered Suriana maritima, Scaevola and Tournefortia, with scattered Heliotropium anomalum and Sida fallax and the semi-parasitic vine, Cassytha filiformis, climbing on some of the larger plants. Common fauna include ghost crabs te kaviki Ocypoda cerathopthalma and striate surf clams te katura Atactodea striata, as well as two land hermit crabs, known generally as te makauro, but specifically as te wi ura Coenobita perlatus and te wi ro C. rugosa, which are found in abundance straying from the surrounding vegetation or coral ramparts (Thaman et al., 1997).

\section{Coral Rubble Ramparts}

There are also areas of extensive coral rubble ramparts composed of large, slab-like, water-worn and weathered hard coral pieces, some weighing over $10 \mathrm{~kg}$. These ramparts, which in some places rise to up to 3-5 $\mathrm{m}$ above sea level, are an indication of the power of the waves and storm surge that affect some coasts of the island. The main concentration of these coral ramparts extends from Northeast Point south along the Bay of Wrecks to just north of Artemia Corner, and in scattered other locations on east- and west-facing coasts (e.g., about $1 \mathrm{~km}$ west of the Captain Cook Hotel and on the northwest coast of Cook Island). The fauna in these areas consists mainly of land hermit crabs and grapsid shore crabs te

kamakama Grapsus albolineatus. These ramparts, especially along the Bay of Wrecks, are very scenic and constitute a unique island environment of considerable international importance (Thaman et al., 1997; Thaman and Tuxson 1997).

\section{Sand Dunes}

There are a number of concentrations of well-formed sand dunes that have developed over thousands of years due to the strong winds and rough seas, and which rarely attain elevations greater than $2-3 \mathrm{~m}$ above sea level. The main concentrations of sand dunes (referred to locally as sand ridges) include (1) Joe's Hill, just to the south of the Bay of Wrecks, which attains an estimated elevation of $15 \mathrm{~m}$ above sea level; (2) a number of smaller, lower dunes just inland from the coast between Joe's Hill and Aeon Field; (3) some extensive dunes near the west end of Aeon Field; (4) a sand hill inland from Southeast Point; (5) some lower dunes about $1 \mathrm{~km}$ east of the Captain Cook Hotel; and (6) a small raised area of dunes on the east coast of Cook Island (Thaman et al., 1997; Thaman and Tuxson, 1997).

The vegetation of Joe's Hill is composed mainly of stands of Scaevola taccada and scattered Tournefortia argentea with Cassytha filiformis and scattered, often extensive patches of Lepturus repens and Boerhavia tetrandra, especially on the leeward western side of the dunes. There are also areas with small populations of Heliotropium anomalum and Portulaca lutea on the windward-facing eastern parts of the dunes.

These dunes, in particular Joe's Hill, are ecologically and geologically uncommon in the Pacific islands, and should be protected as reserve areas.

\section{Sand-Clay Plains}

Much of the interior of Kiritimati is made up of flat, low plains bearing a layer of sand-clay soils of varying thickness, derived from the coral substrate. Such areas carry all of the vegetation associations in the bulleted listed above and include the major areas that have been developed for settlements and plantations. They are thus among the most economically valuable habitat types.

\section{Limestone Hardpans}

There are extensive areas of limestone hardpan that form the matrix for countless hypersaline ponds. These areas are colonized by salt-tolerant scrub vegetation, dominated mainly by Suriana maritima, 
Scaevola taccada and Tournefortia argentea, with scattered Heliotropium procumbens, Sida fallax, Portulaca lutea and Cassytha filiformis. They offer little productive potential and constitute important seabird nesting areas, especially near Y Site and the Ngaon te Taake along the eastern side of the central lagoon. Like the sand dunes, they are unique landforms of some scenic and scientific importance and should be kept free from development, including solid waste disposal (Thaman et al., 1997; Thaman and Tuxson, 1997).

\section{Lagoon Islets}

There are a number of uninhabited islets in the main lagoon. Along with Cook Island at the lagoon entrance, Motu Upua and Motu Tabu are among the most important seabird nesting areas on Kiritimati and the most easily protected because of their isolation from the mainland. These three islets should continue to be designated protected, limited-entry areas to ensure that their wildlife and natural environments are preserved for the benefit of ecotourists, scientists and future generations of residents and students (Thaman et al., 1997; Thaman and Tuxson, 1997).

Cook Island also deserves recognition historically as the site where Captain James Cook became the first recorded European to land on the island when he "discovered" it on 24 December 1777 before spending Christmas Day somewhere on Kiritimati.

\section{Lagoons}

Kiritimati carries three main kinds of open water (lagoons). The main lagoon, which opens to the ocean in the west, is tidal with water salinity close to that of the open ocean. Much of the island is, however, made up of a network of smaller, more-or-less land-locked lagoons with many natural and artificial channels between them, which establish a wide range of tidal-salinity regimes. Many of the smaller land-locked lagoons become hypersaline through evaporation, although during periods of heavy rainfall their salinity can become so reduced that they become merely brackish.

\section{NATURAL AND ANTHROPOGENIC VEGETATION TYPES}

As listed in the bulleted list above, the main distinguishable "natural" (i.e., not anthropogenic) vegetation types on Kiritimati include Pisonia forest; Tournefortia woodlands; Tournefortia-Scaevola littoral forest and scrub; Scaevola, Suriana and mixed scrublands; and Lepturus and mixed herblands. The main anthropogenic vegetation types include coconut plantations, village and houseyard gardens, and ruderal vegetation, all in various stages of management. In many areas these vegetation types form a patchwork, intergrade with each other and constitute mixed categories or transition zones between vegetation types.

\section{Pisonia Forest}

Although Pisonia grandis is the dominant tree on many uninhabited atolls and atoll islets in Kiribati and elsewhere in the Pacific, there are only three stands of Pisonia on Kiritimati (Garnett, 1983). These are (1) a large stand of an estimated 200 or more large trees near K Site just inland from Southeast Point; (2) a grove of 70-100 trees on the north-central part of Motu Tabu; and (3) a small stand of trees on the northern part of the island southeast of the JAXA Tracking Station. Pisonia is the most important species used as seabird rookeries in many Pacific islands, and these stands are of critical ecological importance and should be protected as parts of a system of seabird sanctuaries (Thaman et al., 1997).

The large stand near K Site, the only large Pisonia grove on the main island, is surrounded by Tournefortia woodland and shrubland, with much Sida fallax. Immediately southwest of the grove is an artificial mound-like hill about $6 \mathrm{~m}$ in elevation covering a bunker, which is almost totally dominated by 
Sida. Further inland from the grove is a Lepturus-Boerhavia herbland savanna with scattered Cassythafestooned Scaevola, behind which are some abandoned Artemia (brine shrimp) ponds, with Sesuvium growing along the edges and along the dividing banks.

\section{Tournefortia Woodlands}

Woodlands and scrublands, and in some cases small dense stands, of Tournefortia argentea, usually below $5 \mathrm{~m}$ in height but up to $10 \mathrm{~m}$ in places (Garnett, 1983), are the main inland vegetation type in many areas, and, depending on the site, grade into Scaevola or Suriana open scrubland and Lepturus grassland and mixed herbland. These are often composed of scattered low-stature Tournefortia trees with mainly Lepturus, Portulaca and Boerhavia in between and in more open areas such as on Cook Island, with extensive areas of Lepturus-Tribulus-Portulaca herblands and scattered Boerhavia, Sida, Heliotropium and sometimes Cassytha. There are also areas of scattered Scaevola and Suriana in coastal woodlands. As mentioned above, there are also remnants of Tournefortia woodland surrounding and near the stand of Pisonia inland from Southeast Point.

These woodlands, particularly on Cook Island, are important nesting sites, particularly for sooty terns, black and brown noddies, white terns, and the red-tailed tropicbird (Thaman et al., 1997).

\section{Tournefortia-Scaevola Littoral Forest and Scrub}

Important in some areas are Tournefortia-Scaevola littoral forest and scrub, which are found on more protected sites in some areas of coastline on the mainland and on lagoon islets, such as Motu Upua, where there is Scaevola in the outer zone with Tournefortia just inland. On the north coast just east of the Captain Cook Hotel, there are almost monospecific stands of Tournefortia, whereas along the south coast and near Southwest Point, there are stands of mixed Tournefortia-Scaevola coastal forest lining the inner margins of the beach, often with Scaevola interspersed or on the ocean side of the Tournefortia. On Cook Island and Motu Upua a number of Cordia subcordata trees grow in the coastal zone, as do a number of scattered coconut palms, which may have been planted as part of conservation efforts (Thaman et al., 1997).

\section{Scaevola, Suriana and Mixed Scrubland}

The most widespread and dominant vegetation type on the island is Scaevola scrubland (Garnett, 1983), which varies from extensive, almost monospecific stands to scattered clumps with open areas of grassland, herbland or low scrub in between. The latter formation is common on the less favorable, drier hardpans or more exposed coastal sites. In the northeastern part of the island between Cape Manning and Northeast Point, very low, windswept Scaevola scrub dominates the areas inland from the coral shingle rampart, with Heliotropium anomalum in scattered patches in some areas of coral shingle, and patches of Sesuvium on the inner portions of the coral rubble. There are also Portulaca-Sida-Boerhavia herblands and other mixed herblands, many of which are important nesting sites for some seabirds, including the great frigatebird, lesser frigatebird, masked booby and red-footed booby (which nest in Tournefortia and Scaevola scrub south of Y Site), and the blue-grey noddy (which nests in the natural camouflage of the Heliotropium-Portulaca-Sida herblands on Cook Island and Motu Tabu). On Motu Upua there are relatively dense areas of predominantly Suriana shrubland, mostly in sandier beachward sites.

To the east of Poland and in a number of other highly saline sites, such as around many of the hypersaline ponds, there are almost monospecific stands of Suriana maritima, which intergrades with Scaevola and other species, such as Heliotropium, on the margins. On sandy areas on the eastern coast of Cook Island, there are some almost monospecific areas of scattered Heliotropium with white sand in between.

Sida scrub, growing to $2 \mathrm{~m}$ high, is found particularly abundantly on the coastal plain along the south coast, but also occurs on sandy soils near inland ponds and the eastern shores of the main lagoon, 
associated with colonies of burrowing wedge-tailed shearwaters (Garnett, 1983). On the Southeast Peninsula and elsewhere the Sida is prostrate in habit and better described as forming a dwarf scrub (Garnett, 1983).

In open areas along the southern coast small patches of scrub or dwarf scrub dominated by Hedyotis romanzoffiensis with Lepidium bidentatum occur on limestone hardpan and rubble (Garnett, 1983).

\section{Lepturus Grasslands and Mixed Herblands}

There are extensive Lepturus grasslands in a number of sites on the island, including (1) just north of Tabwakea Village; (2) in the center of the northern part of the island between Northwest Point and Cape Manning; (3) a large area extending east from Cassidy Airfield toward Northeast Point; (4) south of Aeon Field, and near Dakota Strip and extending to the west on the southeast peninsula; (5) west of Tahiti and south of Te Kaba (New Zealand Airfield); (6) the Poland plains, just north of Poland village in the southwest; and (7) small areas on Cook Island, Motu Tabu and Motu Upua. On Cook Island there are extensive areas of Lepturus-Portulaca-Tribulus herblands with scattered Boerhavia, Sida, Heliotropium and sometimes Cassytha, in varying proportions.

The dominant species in these areas is Lepturus repens, sometimes in almost monospecific open stands, often with sand in between in more coastal sites such as near Southwest Point. Other important species in the Lepturus and mixed herblands include Portulaca lutea, Tribulus and Boerhavia tetrandra, with scattered Tournefortia trees and commonly small populations or clumps of Scaevola or Heliotropium anomalum, both commonly festooned with Cassytha filiformis. There also sites near the hypersaline ponds and in sandy sites on lagoon islets, such as Motu Upua and Motu Tabu, where there are almost monospecific areas of Sesuvium. These constitute some of the more favorable bird nesting sites, especially for shearwaters Puffinus spp. and boobies Sula spp. Attempts should made to ensure the protection of the more favorable sites, particularly those on Cook Island, Motu Tabu, Motu Upua and south of Y Site (Thaman et al., 1997).

In open areas in the scrubland, close to hypersaline ponds, there is a variable mixture of Lepturus, Heliotropium anomalum, Portulaca lutea and Sida fallax, often forming what amounts to a dwarf scrub rather than an herb-dominated formation (Garnett, 1983). Cassytha is also an important component, in some cases festooning the shrubby vegetation and trees or as a terrestrial creeping component of the herbaceous vegetation.

\section{Other Natural Vegetation Types}

In sandier sites, such as on the narrow isthmus south of the former South Pacific Airways Hotel, Suriana maritima is found along with Scaevola, Tournefortia and Cassytha. Herb mats with Heliotropium anomalum, Boerhavia, Portulaca lutea and Cassytha are found to the north of Poland on the peninsula.

Around the hypersaline ponds, which are affected by tidal fluctuations, there is often clear zonation, with Sesuvium mats growing closest to the ponds in areas most affected by high waves and salt spray during times of high winds and high tides, then Heliotropium on the slightly higher more well-drained areas, and then Scaevola or Suriana further inland, sometimes in almost monospecific stands and sometimes mixed. Sesuvium is also occasionally found along more protected beaches, such as on the northwestern side of Motu Upua. In some more sheltered sites there are also scattered individual trees or stands of Tournefortia. On the more exposed sandier, rockier or hardpan sites, such as on Ngaon te Taake, Suriana is more dominant, with Lepturus more common in sandier sites between the larger shrubs. Fimbristylis, probably a recently introduced species, seems more suited to areas where asphalt-like hardpans are found. Also found in drier, rockier sites are Sida fallax and Portulaca lutea. 


\section{Coconut Plantations}

Although the main opportunities for export income and the generation of foreign exchange in Kiritimati are related to the marine resources, ecotourism and small developments such as the JAXA Tracking Station, coconut plantations and the other plants that people cultivate and protect in villages and houseyard gardens provide for some cash and many subsistence needs. They are the basis for sustainable living in the dry atoll environment of Kiritimati, and their protection, maintenance and perhaps further planting must be seen as integral to any further resettlement.

The coconut palm is still the "tree of life" to the I-Kiribati, and copra remains a source of livelihood for many people on Kiritimati. The income received is not great, but provides limited cash needed to purchase some necessities from the outside economy. Along with fish, coconut constitutes the main locally produced staple food. It is also the source of toddy (both sweet and fermented, made from the sap of the coconut flower spathe), fuel, medicine, thatch, timber, oil and a wide array of other products of economic and cultural value (Thaman et al., 1997).

The most extensive coconut plantations are found in the south-central part of the island, and in the north between Cassidy Airport and Northwest Point. Scattered throughout the plantations, depending on the state of maintenance and disturbance, are elements of Lepturus grasslands and herblands, scrub and ruderal vegetation.

\section{Village Gardens}

Village and houseyard gardens contain a range of important food trees, crops and other culturally and ecologically valuable plants and ornamentals, most of which have been introduced to Kiritimati from the wetter Line Islands of Teraina and Tabuaeran or from the main Gilbert Group and Nauru (where many IKiribati have worked as contract laborers for years). There have also been numerous introductions from Fiji, Hawaii or other areas in Micronesia, such as Guam, which have, over the years, been the main direct air connections to Kiritimati.

Important trees and shrubs in village gardens include coconut palms te ni Cocos nucifera, edible pandanus te kaina Pandanus tectorius, breadfruit te mai Artocarpus spp., tropical almond te kunikun Terminalia catappa, native fig te bero Ficus tinctoria, Alexandrian laurel te itai Calophyllum inophyllum, sea trumpet te kanawa Cordia subcordata, guettarda te uri Guettarda speciosa, noni te non Morinda citrifolia, beach hibiscus te kiaiai Hibiscus tiliaceus, frangipani te meria Plumeria spp., sebesten plum Cordia sebestina, hibiscus te roti Hibiscus rosa-sinensis, lantana te kaiboia Lantana camara, hedge panax te toara Polyscias spp., and a small range of other ornamentals.

There has also been, over the years, official promotion of the establishment of small houseyard vegetable gardens. The main plants found in these gardens include Chinese cabbage te kabiti n Tiaina Brassica chinensis, pumpkin te baukin Cucurbita moschata, amaranth spinach te moota Amaranthus spp., hibiscus spinach te bere Abelmoschus manihot, chili peppers te beneka Capsicum spp., tomato te tomato Solanum lycopersicum, eggplant te baigani Solanum melongena, canteloupe melon te meren Cucumis melo, cucumber te kukamba Cucumis sativus, sweet potato te kumara Ipomoea batatas, cassava te tabioka Manihot esculenta, papaya te babaia Carica papaya, the drumstick tree te kai turam Moringa oleifera and chaya te tiaia Cnidoscolus chayamansa.

Almost all of the plants cultivated in villages and houseyard gardens are culturally and economically essential for habitation on Kiritimati. The increased planting of trees and a wide range of other plants and the maintenance of small food gardens should be an integral component of all development programs on the island.

\section{Ruderal Vegetation}

Increasing urbanization, including the expansion of settlements and the development of roads, airports, schools and other infrastructure, has created extensive areas of continually disturbed ruderal 
vegetation. These include roadsides, pathsides, waste places, pigpens, open lots, unpaved areas around parking lots, airports and old landing strips, and other areas that are continually disturbed or not maintained (e.g., neglected houseyard gardens). Although indigenous species such as Lepturus repens are found in ruderal sites, these are the main places where easily dispersed, fast-growing, weedy shrubs, grasses, sedges and other herbs are found, most of which have been accidentally introduced over the past century.

Common introduced grasses (Poaceae) in ruderal areas include Cenchrus echinatus, Eleusine indica, Eragrostis tenella and Eustachys petraea, the last only seen since 1996 but now increasingly widespread. Other uncommon to rare grasses include Chloris barbata and Dactyloctenium aegyptium.

Common to occasional sedges (Cyperaceae) include Fimbristylis cymosa, Cyperus rotundus, $C$. compressus, Kyllinga nemoralis, Mariscus javanicus and Pycreus polystachyos.

Common weedy dicotyledons include the herbaceous spurges Euphorbia cyathophora, Chamaesyce prostrata, C. hirta, C. hypericifolia, C. thymifolia and Phyllanthus amarus, Cyanthellium cinereum, Tridax procumbens, Portulaca oleracea and Cuscuta campestris, a leafless parasitic vine, which is locally common in the southeast of the island. Other less common species found in a few disturbed habitats include Senna occidentalis, Passiflora foetida, Oldenlandia corymbosa, Spermacoce assurgens and Physalis angulata. Locally common weedy shrubs include Turnera ulmifolia, Leucaena leucocephala, Senna occidentalis, Pluchea spp., and Sida rhombifolia.

We found many more recently introduced species than had been reported before our studies. Up to 2012, many of these were still only present in cultivation, but some were already invasive, including Eustachys petraea (first recorded 2006), already among the most common and widespread introduced grasses, and Amaranthus dubius (1996), Heliotropium procumbens (2006) and Senna occidentalis (1996), all three now among the commonest weeds in London. Perhaps worst of all, Turnera ulmifolia (2006) had already naturalized in London and Poland by 2008, and by 2012 was widespread in ruderal sites from London to Main Camp, including in areas of semi-natural vegetation; it looks likely to become one of the more successful shrubby invaders on the island.

Some other notorious invaders elsewhere have been present on Kiritimati for some time but have not (yet) become seriously invasive, including Catharanthus roseus (1996), Cryptostegia madagascariensis (1996), Bidens pilosa (1980), Chromolaena odorata (2006, one record, possibly died out), Leucaena leucocephala (1936) and Spathodea campanulata (2006); the generally dry climate and harsh soils of Kiritimati are presumably not suitable for them. Spermacoce assurgens was first recorded in the wet year of 2008, when it was common and widespread in the northwest of the island, but was not found thereafter; some other weeds may similarly only become evident under such unusually favorable conditions. A few other weedy plants, reported present in the past, seem never to have become common and perhaps have died out, including Cenchrus ciliaris (2006, one record), Panicum maximum (1934, one record), Verbesina encelioides (1965-1982), Sida rhombifolia (1924, one record).

\section{TERRESTRIAL FLORA}

The indigenous flora of Kiritimati is very limited due to the island's extreme isolation, low rainfall, frequent prolonged droughts and extremely poor soils. The latter factors also place limits on the establishment of species introduced by people. However, there has been extensive human disturbance for over a century, from coconut planting, military occupation of the island during World War II and for nuclear testing by the British and Americans in the 1950s and 1960s, and resettlement of the island by IKiribati from the more populous islands of the Gilbert group after independence in 1979. The following analysis is based on our own surveys from 1996 to 2012 and other species reported in the past (referenced in the species accounts). 
The number of vascular plant species that have been reported at some time on Kiritimati, including all indigenous and introduced species (whether in cultivation or not) is 168, plus 3 hybrids and 3 additional varieties, for a total of 174 taxa, all of which are discussed in detail in the annotated list. Of these, three records are doubtful (two Boerhavia spp. and one Musa taxon), leaving a reliably reported total of 171 taxa in 166 species. Only 10 of the reported taxa (Eragrostis ciliaris, E. paupera, Panicum maximum, Verbesina encelioides, Barringtonia asiatica, Acalypha amentacea, Erythrina variegata, Macroptilum lathyroides, Sida rhombifolia, Waltheria indica) were not seen by RRT or AT, and of these at least six (Panicum maximum, Barringtonia asiatica, Acalypha amentacea, Erythrina variegata, Macroptilum lathyroides, Waltheria indica) have probably died out on the island, leaving an extant flora of around 165 reliably recorded taxa (including the hybrids and varieties) in 160 species.

The total flora, including the hybrids, varieties, doubtful taxa and those that may have disappeared, includes 42 monocotyledons and 132 dicotyledons. There have been no indigenous or introduced ferns or gymnosperms recorded on the island, although on the wetter northern Line Islands a number of ferns are found and a "few large" Araucaria pines were seen as planted ornamentals around the Cable Station on Tabuaeran in 1982 (Wester, 1985).

\section{Indigenous and Questionably Indigenous Species}

Of the 167 plant species reliably recorded on Kiritimati, probably only 15 (9\%) or perhaps up to 19 are native; in other words, some $90 \%$ of the present-day flora is introduced. Only three monocotyledons, all grasses, appear to be indigenous: Digitaria stenotaphrodes, Eragrostis paupera and Lepturus repens. Lepturus is the only abundant indigenous grass on the island.

The most abundant indigenous woody species include te mao Scaevola taccada and te ren Tournefortia argentea, which are dominant in most coastal sites and in many inland areas, and te aroua Suriana maritima, which is particularly common in calcareous hardpan sites and on beaches on lagoon islets. Te kaura Sida fallax, te wao Boerhavia spp., te boi Portulaca lutea, and Heliotropium anomalum are herbaceous or subshrubby native species that dominate herbland sites, while te boi ntari Sesuvium portulacastrum dominates saline sandy and clay soils, especially around lagoon margins. The semiparasite te ntanini Cassytha filiformis commonly festoons vegetation throughout the island. Two less common indigenous dicotyledons are Lepidium bidentatum and Hedyotis romanzoffiensis, which are most abundant growing together on calcareous hardpan along the south coast.

Three species indigenous to some central Pacific islands, including other Line Islands, and sometimes considered native to Kiritimati but more likely introduced there by people include the sedge Fimbristylis cymosa, which was not recorded until 1962, and the useful plants te buka Pisonia grandis and te kanawa Cordia subcordata, which were perhaps introduced by early Polynesian visitors or during the early European colonization period. The seabird-dispersed Pisonia grandis was first recorded in 1924 and is found in three isolated stands, one on Motu Tabu, one inland from the JAXA Tracking Station near Northwest Point, and one near K Site on the Southeast Peninsula. The seawater-dispersed Cordia subcordata is found in a few coastal locations in the northern part of the island, the Southeast and Paris peninsulas, and on lagoon islets. It was not reported until the 1970s by Roger Perry, who considered it introduced, and the current trees, although found in coastal vegetation, may be descendants of deliberate plantings.

Three more species useful to people that are even less likely to be native to Kiritimati include te kiaiai Hibiscus tiliaceus, also dispersed by floating seeds and first reported in 1924, but then and since only recorded in settlements or persisting from former cultivation (as at Paris). Pandanus te kaina Pandanus tectorius was also first reported in 1924, but has only been found where clearly planted by people. The coconut palm Cocos nucifera was first documented by Captain Cook in 1777, in a grove most likely planted by Polynesians. Any of these species could conceivably have arrived naturally at one time or other in the past, but the extant populations all seem to derive from introductions by people.

Abutilon indicum, probably also known as te kaura (same name as for Sida fallax), is a problematic species whose records suggest it might be indigenous, although it is not known to be native elsewhere in 
Oceania. It is rare but was recorded in 1936 and the 1980s in sites where it seems unlikely to have been planted deliberately or introduced unintentionally. However, in 2006 it was found planted in one garden, possibly from a separate introduction by people.

\section{Introduced Flora}

The introduced flora includes a range of grasses, sedges, herbs and other weedy species, plus cultivated food plants, ornamentals and other useful plants, some of which have naturalized. Some 54 species, including both unintentional introductions and escapes from cultivation, have naturalized, while the evidence for an additional five having naturalized remains inconclusive to date.

Useful species have been deliberately planted on Kiritimati at least since its European discovery. Cook (1874) planted yams, melons and coconuts on Cook Island, which could not be found by Bennett (1840), while the crew of Bennett's ship planted there "seeds of celery, pumpkin, and orange; as well as arrow-root, sweet-potatoes, and turmeric-root," which do not seem to have survived either.

Some species that are indigenous to other islands of Kiribati are certainly introduced on Kiritimati. Many of these are only found in settled areas. Some widespread coastal strand plants that are indigenous to the region, including the wetter inhabited islands in the Lines group (Teraina and Tabuaeran), and islands of the Gilbert group, appear to have been introduced by humans to Kiritimati from these islands. These include (first records in parentheses) the prostrate herb te kiaou Triumfetta procumbens (2006; an important I-Kiribati medicinal plant), the vines te ruku Ipomoea macrantha (1996) and te kitoko Vigna marina (1996), the shrubby scrambler te inato Clerodendrum inerme (c. 1980), and the trees te itai Calophyllum inophyllum (c. 1980), te uri Guettarda speciosa (1964), te kiaiai Hibiscus tiliaceus (1924), te non Morinda citrifolia (c. 1978), te ango Premna serratifolia (1996), te kunikun Terminalia catappa (c. 1978) and te ukin T. samoensis (1996). All of these are found cultivated in houseyard and village gardens.

Common recently introduced ruderal species include the grasses Cenchrus echinatus (1959), Chloris barbata (c. 1978), Eleusine indica (c. 1959) and Eragrostis tenella (1924), and the sedges Fimbristylis cymosa (1962), Mariscus javanicus (c. 1980), Cyperus compressus (1982) and C. rotundus (1936). A grass that has spread rapidly from where it was first seen near the airport in 1996 is Eustachys petraea, a tropical American species that is now a common weed along roadsides in the settlements from London to Banana.

Common weedy dicotyledons include the herbaceous pigweed Portulaca oleracea (1936), Spermacoce assurgens (2008), the spurges Chamaesyce prostrata (1982), C. hirta (1924), C. hypericifolia (1982), C. thymifolia (1996) and Phyllanthus amarus (1924), and four composites, ironweed Cyanthellium cinereum (1924), the shrubby Indian and American plucheas Pluchea indica (1962) and $P$. carolinensis (1958), and a hybrid P. x fosbergii (1964), which is now common in waste places in London. Golden dodder Cuscuta campestris (1965), a leafless parasitic vine, is locally common in the southeast of the island. Other less common species found in a few disturbed habitats include Senna occidentalis (1996), Passiflora foetida (1996), Physalis angulata (1982) and Sonchus oleraceus (2011, one site, where all individuals were removed).

Deliberately introduced monocotyledons include the food plants giant swamp taro te babai Cyrtosperma chamissonis (1965) and sugarcane te kaitioka Saccharum officinarum (1996), the ornamental lilies te kiebu Crinum asiaticum (c. 1980) and C. xanthophyllum (2006), spider lily te ruru Hymenocallis littoralis (2006), pink zephyr lily Zephyranthes rosea (1996) and sisal te robu Agave sisalana (c. 1980).

Other common introduced food plants include breadfruit te mai Artocarpus altilis (1962) and A. mariannensis, papaya te babaia Carica papaya (1962), native fig te bero Ficus tinctoria (c. 1978), lime te raim Citrus aurantiifolia (1996), sweet potato te kumara Ipomoea batatas (c. 1978), hibiscus spinach te nambere Abelmoschus manihot (1996), Chinese cabbage te kabiti n Tiana Brassica chinensis (1996) and the hybrid cabbage Brassica x "Saladeer" (1996), and pumpkin te baukin Cucurbita moschata (c. 1980). Less common food plants found in houseyard gardens and in the small fenced food gardens 
promoted by the local health authorities include amaranth spinach te moota Amaranthus spp. (1996), sweet capsicum and annual chili peppers, te beba and te beneka Capsicum annuum vars (1996), perennial chili peppers te beneka $C$. frutescens (c. 1980), cantaloupe melon te meren Cucumis melo (1996), cucumber Cucumis sativus (c. 1980), bottle gourd Lagenaria siceraria (1996), watermelon Citrullus lanatus (1996), holy basil te marou Ocimum tenuiflorum (1996), eggplant te baigani Solanum melongena (1996), the drumstick tree te turam Moringa oleifera (1996), and chaya te tiaia Cnidoscolus chayamansa (2006), which was introduced in the early 1990s as part of the European Union Pacific Regional Agricultural Project (PRAP) and has now become a widespread, well-adapted, important spinach on the island.

The useful trees casuarina te katurina Casuarina equisetifolia (1964) and leucaena te kaitetua Leucaena leucocephala (1936) are both established and the former is common in settlements.

Common ornamental trees or shrubs that seem to do well in the harsh atoll environment of Kiritimati include frangipani te meria Plumeria spp. (1982), yellow bells neikarairai Tecoma stans (1996), false eranthemum te iaro Pseuderanthemum carruthersii vars (c. 1980), bougainvillea te akanta Bougainvillea x buttiana (c. 1980), hedge panax te toara Polyscias spp. (1996), hibiscus te roti Hibiscus rosa-sinensis (1962), lantana te kaibuaka Lantana camara (c. 1980), oleander te orian Nerium oleander (c. 1980), geiger tree te kanawa ni Imatang Cordia sebestena (c. 1978) and yellow elder te kakai nea Turnera ulmifolia (2006), which, since 2008, has begun rapidly spreading into native vegetation. Other less common ornamentals include Tahitian gardenia te tiare Gardenia taitensis (1996), ixora te katuru Ixora casei (1996), marvel of Peru te awa owa Mirabilis jalapa (1964), slipper flower Pedilanthes tithymaloides (1996), and the annuals marigold te merikora Tagetes erecta (1996) and zinnia te tinia Zinnia violacea (1996). Ornamentals seen only as single specimens included bauhinia Bauhinia malabarica (1996), croton Codiaeum variegatum (1996) and sunflower Helianthus annuus (1996); some of these may have since died out. The most common street trees seen in London were Calophyllum inophyllum, Cordia subcordata, Terminalia catappa and Hibiscus tiliaceus, all indigenous to the Pacific islands but probably introduced deliberately to Kiritimati.

New useful plants continue to be introduced to the island, some of them introduced by the Agricultural Station, with the following seen only there and only since 2008: taro te taororo Colocasia esculenta (2009), ti plant te rauti Cordyline fruticosa (2008), flame tree te tua Delonix regia (2009) and the common fig te biku Ficus carica (2009).

\section{INTRODUCTION TO THE ANNOTATED LIST}

In the annotated list that follows, we present the monocotyledons before the dicotyledons, with each group organized alphabetically by families, then genera, and then species.

\section{Plant Status}

We categorize the abundance of plants as follows:

Introduced and Exotic - Species known or considered to have been introduced to the island deliberately or unintentionally by people.

Indigenous and Native - Species thought not to have been introduced by people.

Recent introduction - Species introduced since Captain Cook's visit (1777).

Aboriginal introduction - Plants probably introduced by earlier Polynesian or Micronesian visitors.

Extirpated - The species once occurred on Kiritimati (known from reliable records) but does so no longer; in most cases we state "probably" extirpated, since the possibility remains that a species has been recently overlooked.

In some cases, a species may have arrived and established itself naturally, subsequently disappeared (become extirpated) due to some extreme event, such as a prolonged drought, storm surge or tsunami, and then been deliberately or accidentally reintroduced by humans. 


\section{Abundance}

We categorize the abundance of plants as follows:

Very abundant - Abundant in large areas or most habitats, and dominant in many sites or habitats.

Abundant - Widespread in a range of habitats, or dominant in several different habitats throughout the island.

Common - Found in many locations but not dominant, or locally abundant or dominant in a few locations.

Occasional - Occasionally seen but in a number of places, or locally common in only a few locations.

Uncommon - Found in only a few locations, including in undisturbed sites, as remnants in previously settled areas, or in a few houseyard gardens or experimental agricultural areas. This category could also pertain to plants, such as annual flowers or food plants, that are seasonally planted and were not common during the periods of the surveys.

Rare - Found in only one or two locations. Such species may be in danger of extirpation, and include rare ornamentals, food plants, etc., and recent trials that may not prove suited to the Kiritimati environment.

\section{Plant Records and Recorders}

Most of the early plant recorders who collected or made observations on Kiritimati focused mainly on the native and naturalized vegetation. In some cases there was little cultural vegetation due to the limited settlement at the time.

In each species account, we list records in chronological order using abbreviations for the recorder's or recorders' names and years of record, as follows. Dates refer to the periods when the collections or observations were made. We provide an expanded listing of these plant recorders, including affiliations, publications, and other collection details, in the Appendix.

Cook 1777 - Captain James Cook, December 1777

FDB 1835 - Frederick Debell Bennett, May 1835

THS 1874 - Thomas H. Streets and William H. Jones, January 1874

C\&B 1924 - Erling Christopherson and H. F. Bergman, July-August 1924

GPW 1924 - Gerrit P. Wilder, December 1924

SFC 1934 - Harold St. John, F. Raymond Fosberg and Charles Montague Cooke Jr., October 1934 EHB 1935-1938 - E. H. Bryan

F\&M 1936 - F. Raymond Fosberg and Alfred Metraux, August 1936

LWB 1945 — L. William Bryan, October 1945

WFC 1957 - Captain W. F. Curlett, June 1957

FLH 1957 - F. L. Hill, October and November 1957

JPG 1958 - Corporal J. P. Griggs

MDG 1958-1959 — Michael D. Gallagher, June 1958-June 1959

DCH 1962 - Dean C. Hamilton, April 1962

CRL 1964, 1965 - C. R. Long, June and November 1964, June 1965

WAS 1965 - W. A. Sledge, April 1965

RNJ 1965 - R. N. Jenkin, August-September 1965

RP 1977-1979 - Roger Perry, in residence 1977-1979

MCG 1979-1982 - Martin C. Garnett, in residence 1979-1982

RWH 1982 - Robert W. Hobdy, January 1982

LLW 1982 - Lyndon L. Wester, August 1982

RRT 1996 - Randolph R. Thaman, July 1996

HLJ 1997 — H. Lee Jones, May 1997 
RRT 2006 - Randolph R. Thaman, May-June 2006

AT 2008, 2009, 2011, 2012 - Alan Tye, April 2008, September 2009, March 2011, March 2012

For example, "RRT 1996; AT 2009" indicates that the species was found by Thaman and Tye, respectively, in those years. Where AT has examined a specimen collected by someone else, this is indicated by "[AT!]" placed after the recorder's abbreviation and specimen number, followed by the holder of the specimen, (e.g., "DCH 1962, specimen 1[AT!] at BISH"). When an actual specimen is referenced, the recorder's abbreviation may be replaced by the full last name of the collector. This convention is used to identify which member of the group collected the specimen when the abbreviation identifies two or more collectors (e.g., "Fosberg 1936, specimen 12170[AT!] at BISH" rather than "F\&M 1936, specimen 12170[AT!] at BISH").

Herbarium abbreviations in specimen records and throughout the annotated list follow Index Herbariorum usage (http://sciweb.nybg.org/science2/IndexHerbariorum.asp).

\section{Voucher Specimens}

Voucher specimens collected by RRT (in 1996 and 2006) and AT (2008-2012) and deposited at SUVA, the South Pacific Regional Herbarium at The University of the South Pacific (USP), Suva, Fiji, are cited by collector's number thus: "USP" followed by a serial number indicates an RRT voucher specimen; "AT X" followed by a number and locality indicates an AT voucher specimen.

\section{Digital Voucher Photographs}

Most species have voucher photographs taken by RRT in 2006 or by AT in 2008-2012. When such photos are available for a species, they are listed thus: RRT's photos are cited as "DPKR0001, 0002...," with DPKR referring to Digital Photo KiRitimati, and with lower case letters a-e after a number indicating the position of the species in the photo when the photo features more than one species, designated by a (first of two or more species in the photo), b (second of two or more pictured species), c (third of two or more pictured species), $d$ (fourth of two or more pictured species) or e (fifth of two or more pictured species). AT's photos are cited in the form ATYYYYMMDD_nn, for example, AT20090922_38 means photo 38 (of this taxon) taken on 22 September 2009.

The voucher photographs either validate the presence of a species or help confirm its identity. They include close-ups of leaves, branches and trunks or stems of plants with floral and fruiting parts; entire plants; and landscape shots to show the preferred habitats of the species. These digital photos have been copied into computer files in both the School of Geography, Earth Science and Environment and the South Pacific Regional Herbarium at The University of the South Pacific, Suva, Fiji, and in the Agricultural Division at Tenaea and the University of the South Pacific Centre in Teaoraereke, on Tarawa. 


\title{
ANNOTATED LIST OF THE FLORA OF KIRITIMATI ATOLL, NORTHERN LINE ISLANDS, REPUBLIC OF KIRIBATI
}

\author{
ANGIOSPERMAE \\ (ANGIOSPERMS)
}

\section{MONOCOTYLEDONAE \\ (MONOCOTYLEDONS)}

\section{AlliaceAe (ONION FAMily)}

\section{Allium fistulosum L.}

Common Names: Green onion, spring onion, Welsh onion, Japanese bunching onion

Status: Recent introduction. East Asia.

Abundance: Rare.

Remarks: Planted in a garden box with lettuce in a houseyard food garden in Banana in 2006.

Recorded: RRT 2006

Voucher Photographs: DPKR1209a, 1211b

\section{Allium schoenoprasum L.}

Common Name: Chives

Status: Recent introduction. North Hemisphere.

Abundance: Rare.

Remarks: Found in one houseyard food garden in Tennessee in 2006.

Recorded: RRT 2006

Voucher Photograph: DPKR1150

\section{Agavaceae (AgaVe Family)}

\section{Agave sisalana L.}

Common Names: Century plant, sisal, sisal hemp

Kiribati Name: te robu ("rope")

Status: Recent introduction. Mexico.

Abundance: Occasional.

Remarks: First reported in the early 1980s. Planted ornamental in houseyard garden in London in 1996. In 2006-2011 found in a number of houseyard gardens and business premises in London, Tabwakea and Banana, often as a border planting or in containers. Possibly originally introduced as a source of fibre.

Recorded: MCG 1979-1982; RRT 1996, 2006; AT 2008, 2009, 2011

Voucher Photographs: DPKR0172b, 1218, 1219, 1989; AT20080427_28

\section{AMARYLLIDACEAE (AMARYLLIS FAMILY)}

\section{Crinum asiaticum L.}

Common Names: False spider lily, crinum lily, grand crinum

Kiribati Names: te kiebu, te ruru

Status: Recent introduction. Tropical Asia.

Abundance: Common.

Remarks: First reported in the early 1980s, now a planted ornamental in all settlements in houseyard 
gardens, government buildings and other buildings. Often planted as a border or boundary planting along pathways or roads. Leaves used in body ornamentation and local medicine.

Recorded: MCG 1979-1982; LLW 1982; RRT 1996, 2006; AT 2008, 2009, 2011, 2012

Voucher Photographs: DPKR0169, 0196, 0731b, 1256, 2395

Crinum xanthophyllum Hannibal

Common Name: Yellow crinum lily

Kiribati Name: te kiebu

Status: Recent introduction. New Caledonia.

Abundance: Common.

Remarks: Planted ornamental. Found in houseyard gardens and at government buildings in London and Banana in 2006, and in all settlements including Poland in 2008-2009. Often mistaken for a $C$. asiaticum cultivar, which is larger and has green rather than yellow mature leaves.

Recorded: RRT 2006; AT 2008, 2009, 2011, 2012

Voucher Photographs: DPKR0193, 0269, 1927, 2298; AT20080427_07

Hymenocallis littoralis (Jacq.) Salisb.

Synonym: Hymenocallis pedalis (Jacq.) Herbert

Common Name: Spider lily

Kiribati Names: te kiebu, e ruru ni mmane, te ruru

Status: Recent introduction. Tropical America.

Abundance: Occasional.

Remarks: Planted ornamental in a few gardens around government buildings and houses in London and Banana in 2006-2011.

Recorded: RRT 2006; AT 2008, 2011

Voucher Photographs: DPKR1222, 1223, 1295b

Zephyranthes rosea (Lindl.) Green

Common Names: Pink lady, pink zephyr flower, rain lily

Kiribati Name: te riri ("lily")

Status: Recent introduction. Guatemala and West Indies.

Abundance: Rare.

Remarks: Planted ornamental seen in London in 1996; seen again but not in flower, in a container before a statuette in front of the Catholic cathedral in London in 2006. Present on Teraina and Tabuaeran islands (Wester, 1985); I-Kiribati informants on Kiritimati reported it common on Tabuaeran, another atoll in the Line Islands that is much wetter than Kiritimati.

Recorded: RRT 1996, 2006

Voucher Photographs: DPKR1992

\section{ARACEAE (ARUM FAMILY)}

Colocasia esculenta (L.) Schott

Common Name: Taro

Kiribati Name: te taororo

Status: Recent introduction. Originally probably from Indonesia; now cultivated throughout the tropics. Abundance: Rare.

Remarks: According to local informants in 2008, it was formerly cultivated, but is no longer, although in 2009 plants recently imported from Samoa were seen in cultivation at the Agricultural Station, but were no longer present in 2011 and 2012.

Recorded: AT 2009

Voucher Photograph: AT20090922_37 
Cyrtosperma chamissonis (Schott) Merr.

Common Name: Giant swamp taro

Kiribati Names: te babai, te bwabwaia

Status: Aboriginal or recent introduction. New Guinea and western Pacific islands, to Micronesia and Polynesia.

Abundance: Rare.

Remarks: If introduced by early Polynesians, would probably have died out without continuous care. Not documented until 1965, when grown, but neglected, in a small pit near the airport. Still grown by some in the 1970s (R. Perry, pers. comm.). Seen planted in Tabwakea village in one large, wellmaintained excavated taro pit at a residence in 1996 and 2006. A small population also seen planted near a water faucet in an unexcavated plot next to the maneaba (community meeting house) at the Emanuera Church in London in 2006. In 2008 none found, and local people said that it was formerly cultivated but no longer. Likely to be reintroduced from time to time, and a few plants were being grown in pits at the Agricultural Station in 2012. Very important staple root crop and ceremonial food in Kiribati in the past. Corms cooked as a staple vegetable.

Recorded: RNJ 1965; RP 1977-1979; MCG 1979-1982; RRT 1996, 2006; AT 2012

Voucher Photographs: DPKR0772, 0773, 1644, 2007; AT20120319_31, AT20120319_35

Xanthosoma sagittifolium (L.) Schott

Common Names: Tannia, yautia, cocoyam, American taro

Kiribati Name: te taororo

Status: Recent introduction. West Indies.

Abundance: Rare.

Remarks: A single plant seen in a container at the Agricultural Station in 2006.

Recorded: RRT 2006

Voucher Photographs: DPKR1181, 1182

\section{Arecaceae (PALM FAMily)}

\section{Cocos nucifera L.}

Common Name: Coconut palm

Kiribati Name: te ni

Status: Aboriginal introduction. Southern Asia, Indian Ocean and Pacific islands.

Abundance: Very abundant.

Remarks: First reported in 1777, "a few ... in two or three places. ... the number of which did not exceed thirty" (but see much larger estimate within 60 years, below), and on Cook's map mostly shown just north and south of the lagoon entrance (Cook, 1784), suggesting they had been planted there by earlier visitors. Cook's expedition planted more, on Cook Island (Cook, 1784; Christophersen, 1927). Reported in "extensive groves ... on the west side of the island" in 1835 (Bennett, 1840) which, in 1836, were estimated to comprise about 2000 trees (Benson, 1838), casting some doubt on Cook's estimate (Emory, 1934). Numbers reported as 70,000 in 1905, 17,000 in 1912 (after most had died), 77,000 in 1922, 300,000 in 1927 and 600,000 in the 1950s (Gallagher, 1959; Jenkin and Foale, 1968). Plantations mainly in the north and from the Paris peninsula to just south of Carver Way, with isolated clumps and small plantations elsewhere (MCG map). Now uncommon in coastal strand vegetation, common in villages and household gardens, and abundant in coconut plantations, particularly in the areas along the north coast, inland from the east coast and near Algeria, Tahiti and Poland in the southwest. A number of new plantations have been established as part of coconut replanting schemes since about 1995, including a small plantation to the southeast of Joe's Hill at the base of the southeast peninsula. Scattered trees or small groves seen inland or near the main road, sometimes designating turnoffs to locations along 
the lagoon. Small grove of about 6 trees just inland from the north tip of Cook Island and occasional as scattered trees in the interior herbland of Motu Upua. The "tree of life," major staple food crop and source of drinks, including the juice or "water" from the green nuts and the sap from the flower spathe, which is harvested ("cut") every morning and afternoon from specially selected trees near settlements. Toddy, a dietary staple, is drunk as vitamin-, mineraland energy-rich fresh toddy (kamwaimai) or fermented sour toddy (kaokioki), the locally produced alcolholic beverage. It is also reduced to make brown toddy, widely used as a sweetener in cooking. The major cash crop use is for copra, which is processed into coconut oil and a wide range of other products.

Recorded: Cook 1777; FDB 1835; C\&B 1924; MDG 1958-1959; DCH 1962; RNJ 1965; RP 1977-1979; MCG 1979-1982; LLW 1982; RRT 1996, 2006; AT 2008, 2009, 2011, 2012

Voucher Photographs: DPKR0178a, 0237a, 0238, 0778, 0847, 1107a, 1171, 1195, 1231d, 1508a, 1568, 1594c, 1659, 1830b, 1831b, 1954, 1957b, 2027, 2028, 2290b, 2293, 2300, 2315, 2329, 2332, 2334,2461

\section{Phoenix sylvestris var. robusta}

Common Names: Wild date palm, silver date palm

Status: Recent introduction. India.

Abundance: Rare.

Remarks: Two palms planted along the roadside in a private garden in London, 2006 and 2008.

Recorded: RRT 2006; AT 2008

Voucher Photographs: DPKR1306, 1307, 2383, 2384; AT20080425_01

Pritchardia pacifica Seem. \& Wendl.

Common Names: Pacific fan palm, Fiji fan palm

Kiribati Name: te bam

Status: Recent introduction. Fiji, Tonga, and Samoa.

Abundance: Rare.

Remarks: A single palm, about $2 \mathrm{~m}$ high, in the front of the Betereem ae Boou Kiribati Church in

Tabwakea in 2006-2012, approximately $4 \mathrm{~m}$ high and fruiting in 2009 and 2011.

Recorded: RRT 2006; AT 2009, 2011, 2012

Voucher Photographs: DPKR2024, 2025; AT20090922_44, AT20090922_45

\section{ASPARAGACEAE (ASPARAGUS FAMILY)}

Cordyline fruticosa (L.) A. Chev.

Synonym: Cordyline terminalis (L.) Kunth

Common Name: Ti

Kiribati Name: te rauti

Status: Recent introduction. S and SE Asia, anciently introduced throughout Polynesia.

Abundance: Rare.

Remarks: Young plants in cultivation at the Agricultural Station in 2008; none there in 2011. Important cultural plant for body ornamentation and as an ornamental in many islands in the Pacific.

Recorded: AT 2008

\section{ASPHODELACEAE (ASPHODEL FAMILY)}

Aloe vera (L.) Burm. $\mathrm{f}$.

Common Name: Aloe vera

Status: Recent introduction. North Africa.

Abundance: Rare. 
Remarks: Young plants in cultivation at the Agricultural Station in 2008. None there in 2011.

Recorded: AT 2008

Voucher Photograph: AT20080428_00

\section{COMMELINACEAE (DAYFLOWER OR SPIDERWORT FAMILY)}

\section{Tradescantia spathacea Swartz}

Synonyms: Rhoeo spathacea (Sw.) Stearn, Rhoeo discolor (L'Hér.) Hance.

Common Names: Tradescantia, oyster plant, Moses-in-a-boat, dwarf oyster

Kiribati Name: te ruru ni Buranti

Status: Recent introduction. Mexico and West Indies.

Abundance: Rare.

Remarks: Single potted plant seen at the Agricultural Station in 2006. Not seen there subsequently.

Recorded: RRT 2006

Voucher Photograph: DPKR1183

\section{CYPERACEAE (SEDGE FAMILY)}

\section{Cyperus compressus L.}

Common Name: Summer sedge

Status: Recent introduction. Pantropical.

Abundance: Occasional.

Remarks: Weed of roadsides, pathsides, open lots, parking lots, waste places and other ruderal sites. Seen near airport terminal in 1982 and again there, in car parking area, in 1996. Occasional in roadside and ruderal sites in London, Tennessee, Tabwakea and Banana in 2006.

Recorded: LLW 1982; RRT 1996, 2006

Voucher Photographs: DPKR0191, 0212

\section{Cyperus rotundus $\mathrm{L}$.}

Common Names: Nut sedge, nut grass

Kiribati Names: te mutemute, te uteute

Status: Recent introduction. Cosmopolitan.

Abundance: Abundant.

Remarks: First recorded in 1936, in London. Now abundant in villages, in houseyard and vegetable gardens, around government buildings, cemeteries, roadsides, open lots, waste places and ruderal sites, in 1996 and 2006-2009. Is used to scent coconut oil.

Recorded: F\&M 1936; WAS 1965; RRT 1996, 2006; AT 2008, 2009

Voucher Specimen: AT X006 X028 London

Voucher Photographs: DPKR0052, 0107, 1977; AT20080424_04, AT20080424_14, AT20080424_16

Fimbristylis cymosa $\mathrm{R}$. Br.

Common Name: Beach sedge

Kiribati Name: te uteute ni mane ("men's or male grass")

Status: Indigenous to the region but the evidence reviewed below suggests that it is a recent introduction to Kiritimati. Pantropical.

Abundance: Abundant.

Remarks: Capitate form on Kiritimati appears to be var. microcephala F. Brown. Umbellate form refers to F. cymosa var. spathacea (Roth) T. Koyama (Syn. F. spathacea of Christophersen, 1927; F. atollensis H. St John) (T. Koyama, pers. comm.). Although var. spathacea was found on Teraina and Tabuaeran by C\&B (Christophersen, 1927), he did not find it on Kiritimati, and neither did Fosberg; it is difficult to imagine that these experienced collectors would have missed it had it 
been as common and widespread as it is now. It was first recorded in 1962 (var. spathacea), near the British Bachelor Officers' Quarters in London; later in the 1960s found near the airport, at Aeon Point and near Manulu Lagoon. The capitate form was not recorded until the early 1980s, when it was found at the Captain Cook Hotel and the dock in London, and widespread elsewhere but patchy (MCG map). By the 1980s, the species as a whole was reportedly common over most of the island in low scrub, although apparently not as common as it is now. In 2008-2011, var. spathacea was fairly common in waste places in London and near the airport, and was found throughout the island. Both varieties often occur intermixed, such as between Tabwakea and the Captain Cook Hotel. In the southwest, near copra camps and Poland, the capitate form is far less common than var. spathacea. Grows in clusters or tufts in open and semi-open rocky habitats along ocean and lagoon coasts inland from the beach vegetation; a common, sometimes dominant, component in rockier, drier sites in open herblands; also found on limestone and gravelly areas and hardpans around hypersaline ponds. Found in villages, developed and abandoned sites, growing in cracks in cement or asphalt such as runways and roadsides, and in housyard gardens and other disturbed and open inland sites, such as around pigpens and waste places, commonly on hard dry ground. Var. spathacea has been common on Teraina and Tabuaeran since the 1920s (Wester, 1985).

Recorded: DCH 1962, specimen 1[AT!] at BISH; CRL 1964-1965, specimens[AT!] at BISH; MCG 1979-1982; RWH 1982, specimens 1200 and 1201[AT!] at BISH; LLW 1982, specimens[AT!] at BISH; RRT 1996, 2006; HLJ 1997; AT 2008, 2009, 2011, 2012

Voucher Specimens: var spathacea AT X013 London, X034 Airport; var microcephala X035 Airport Voucher Photographs: DPKR0053, 0155, 1498, 1530a, 1647, 1675, 2467, 2483; AT20080423_01, AT20080423_02, AT20080423_35, AT20080423_43

Kyllinga nemoralis (Forst.) Dandy ex Hutchinson and Dalziel Common Names: White watersedge, white-flowered kyllinga

Status: Recent introduction. Old World tropics.

Abundance: Rare.

Remarks: One very small population found growing with Vigna marina in an open lot near a store just inland from the new fisheries port facility in London in 2006. Probably a recent introduction with construction equipment. Not found subsequently.

Recorded: RRT 2006

Voucher Photograph: DPKR0263a

Mariscus javanicus (Houtt.) Merr.

Synonym: Cyperus javanicus Houtt.

Common Name: Marsh sedge

Kiribati Names: te titania, te ritanin (S, Gilbert Is.), te itaita (N. Gilbert Is.)

Status: Recent introduction. Paleotropical.

Abundance: Occasional.

Remarks: First recorded about 1980. Present along roadsides and in a waste places and ruderal sites in London in 1996 and in London, Tennessee, Tabwakea and Banana in 2006-2009, often along roadsides where water pools up during periods of heavy rain. Most common in Banana.

Recorded: MCG 1979-1982; RRT 1996, 2006; AT 2008, 2009

Voucher Specimen: AT X040 north of London

Voucher Photographs: DPKR1229, 1230, 1239a, 2444, 2445; AT20080426_12, AT20080426_13

Pycreus polystachyos (Rottb.) P. Baeuv.

Synonym: Cyperus polystachyos Rottb.

Common Name: Wild sedge

Kiribati Name: te titania 
Status: Recent introduction. Uncertain origin, but now found throughout tropical and subtropical regions; probably a recent introduction on Kiritimati.

Abundance: Uncommon.

Remarks: Seen only in ruderal sites along roadsides where water pools up after heavy rain. Large patch next to Tekabaia guest house in London in 2006 and 2009; in 2011 much reduced after plot clearance followed by planting of Casuarina, and growth of Pluchea indica and Ipomoea pescaprae, but small patches still present in 2012. Also found in Tennessee in 2006.

Recorded: RRT 2006; AT 2009, 2011, 2012

Voucher Specimens: AT X018 X019 London

Voucher Photographs: DPKR2416, 2447, 2448; AT20090917_02

\section{MUSACEAE (BANANA FAMILY)}

The nomenclature for the genus Musa is confused, with most of the common seedless cultivars or clones being triploid crosses of the fertile species Musa acuminata Colla and M. balbisiana Colla. The Latin binomials $M$. nana Loureiro, $M$. sapientum L., and M. paradisiaca L. are commonly used as follows: $M$. nana for the dwarf Cavendish and M. sapientum for the the taller bananas, which are generally eaten ripe, but which are also cooked throughout the Pacific as starchy staples, and $M$. paradisiaca for the starchier bananas or plantains, which are usually eaten cooked as a staple starch, but occasionally eaten ripe as fruit. The nomenclature most widely used by agronomists is that developed by Simmonds, which classifies all cultivars or clones on the basis of their assumed genetic background, for example, Musa ABB Group would be a triploid cross of one M. acuminata group and two M. balbisiana groups. Both nomenclatural systems are presented here to identify the clones that are currently present in Kiritimati more precisely.

\section{Musa (AAB Group)}

Synonyms: Musa acuminata Colla x Musa balbisiana Colla; M. sapientum in Garnett (1983)

Common Names: Ney Poovan, lady's finger, Simmonds lady's finger banana

Kiribati Name: te banana

Status: Recent introduction. S. India.

Abundance: Occasional.

Remarks: Bananas of this group planted in houseyard gardens in all settlements at least since the 1970s; about 10 young plants in pit cultivation at the Agricultural Station in 2012.

Recorded: MCG 1979-1982; RRT 1996, 2006; AT 2008, 2012

Voucher Photographs: DPKR0803, 0809, 1269

Musa (ABB Group)

Synonyms: Musa x paradisiaca L. var. hort. Bluggoe (M. acuminata Colla x M. balbisiana Colla)

Common Names: Simmonds cooking banana, plantain, bluggoe

Kiribati Names: te banana, te umuum

Status: Recent introduction. SE Asia and Pacific.

Abundance: Occasional.

Remarks: Cooking bananas found in houseyard gardens in London. Important traditional supplementary staple in many areas of the Pacific, including the Gilberts, where it seems to be aboriginally introduced. Reportedly present on Teraina from at least 1854 (Wester, 1985).

Recorded: LLW 1982; RRT 2006; AT 2008

Voucher Photographs: DPKR0226, 0227, 1913, 1914

Musa undetermined cultivars

Remarks: Many observations 2008-2012 were not determined to cultivar. Also, new cultivars were introduced by SPC at the Agricultural Station in 2009 but could not be identified by us or our 
informants.

Recorded: RRT 1996, 2006; AT 2011

Voucher Photographs: DPKR0185, 0221, 1163; AT20090922_36, AT20120319_36

\section{PANDANACEAe (PANDANUS FAMily)}

The nomenclature for the genus Pandanus is, like Musa, confused, with some taxonomists classifying many of the common cultivars and wild clones or species, both edible and non-edible, as forms or varieties of $P$. tectorius. Other taxonomists consider them distinct species, often listing numerous species or varieties for a given area. Here we group all records under P. tectorius.

\section{Pandanus tectorius Park.}

Common Names: Pandanus, screw pine

Kiribati Names: te kaina (cultivated varieties), te rekinibeti (wild varieties)

Status: Indigenous to the region but possibly an aboriginal or recent introduction to Kiritimati, perhaps from Teraina in the wetter northern Line Islands.

Abundance: Common.

Remarks: In 1924, the 1950s and 1965, only found where clearly planted, at London, Poland and at Four Wells. Still seen planted in houseyard gardens and around all main settlements, and occasionally elsewhere, including uncommonly growing wild in natural vegetation, in disturbed savannas within view of the roadside on the northwest of the island. Several cultivars, important for fresh fruit and as a staple food, and as the most important timber for construction of traditional houses and maneaba (sacred meeting houses).

Recorded: C\&B 1924; MDG 1958-1959; RNJ 1965; RP 1977-1979; MCG 1979-1982; RRT 1996, 2006; AT 2008, 2009, 2011, 2012

Voucher Photographs: DPKR0173b, 0698, 0711, 0848, 1213b, 1238, 1319, 1320, 2305, 2338a, 2344; AT20080428_36, AT20080428_37

\section{Poaceae (Grass FAMily)}

For nomenclature of the Poaceae we follow Clayton and Snow (2010).

\section{Cenchrus ciliaris L.}

Common Name: Buffel grass

Status: Recent introduction.

Abundance: Rare.

Remarks: Hot, dry parts of India. Seen along fence in port areas where salvaged iron and machinery were being stockpiled before shipping out as scrap in 2006; not found in same area when searched in 2008 and 2009.

Recorded: RRT 2006

Voucher Specimen: USP2K02607

Voucher Photograph: DPKR0063, 0065, 0066

\section{Cenchrus echinatus L.}

Common Names: Burgrass, sand bur

Kiribati Names: te anti, te kateketeke

Status: Recent introduction, probably during WWII. Tropical America.

Abundance: Common.

Remarks: Weedy annual first reported in 1959; found in 1962 in disturbed sites in the north (Main Camp, airport), and in the 1980s found there and elsewhere (London, Tabwakea, Dakota Strip and the area around Poland) (MCG map). Now occurs in clusters or tufts along roadsides, open lots, 
houseyard gardens, waste places and ruderal habitats in all settlements, around government buildings and resorts and at Aeon Field. Virtually disappears during dry periods: after a threemonth dry spell in March 2011, only found at the airport (a few plants). A troublesome weed with thorny burrs that is well adapted to the atoll environment and a potentially serious invasive species. It should be kept off bird islands, removed from tourist destinations and generally controlled wherever found.

Recorded: MDG 1958-1959; DCH 1962; MCG 1979-1982; LLW 1982; RRT 1996, 2006; HLJ 1997; AT 2008, 2009, 2011, 2012

Voucher Specimen: AT X023 London

Voucher Photographs: DPKR0121, 1185, 1240, 1601; AT20080424_08, AT20080427_33

Chloris barbata (L.) Sw.

Synonym: Chloris inflata Link

Common Names: Finger grass, swollen fingergrass

Kiribati Name: te uteute ("grass" in general)

Status: Recent introduction. Tropical America.

Abundance: Uncommon.

Remarks: First recorded in the late 1970s. In 1996 and 2006 seen only in isolated clusters or tufts along roadsides in a couple of locations near the main new port area in London. Apparently more common and widespread in open and ruderal places in 2008 and 2009, although still seen only in London. Seems to be localized in this area, with the similar but more recently introduced Eustachys petraea taking over as a roadside and ruderal weed in other places.

Recorded: RP 1977-1979; MCG 1979-1982; RRT 1996, 2006; AT 2008, 2009

Voucher Specimen: AT X026 London

Voucher Photographs: DPKR0129, 0130, 0260, 0264, 2398b; AT20080427_01, AT20080427_03

Dactyloctenium aegyptium (L.) Beauv.

Common Names: Four-finger grass, beach wiregrass, crowfoot grass

Kiribati Name: te uteute ("grass" in general)

Status: Recent introduction. Palaeotropics.

Abundance: Rare.

Remarks: First recorded in 2006, as a roadside weed at the Kiritimati Island Council office, near the port in London. In 2009 the patch in front of the Island Council building was still there, and also found in a patch behind the wharf area, approximately $500 \mathrm{~m}$ to the east.

Recorded: RRT 2006; AT 2009

Voucher Specimens: AT X008 X009 wharf, London; USP2K02606

Voucher Photographs: DPKR0165, 0166; AT20090917_03

Digitaria stenotaphrodes (Nees ex Stued.) Stapf.

Synonyms: Panicum stenotaphroides Nees (of Christophersen, 1927); Digitaria pacifica Stapf. (see Fosberg, 1939; Gardner, 2007; Clayton and Snow, 2010)

Kiribati Name: te uteute ("grass," general)

Status: Indigenous.

Abundance: Now apparently rare; an annual that has either declined severely, or perhaps been recently overlooked among the now abundant, superficially similar, introduced grasses such as Eleusine and Eustachys.

Remarks: In 1924, the 1930s and 1980s, widely distributed and apparently common, especially in slacks behind beach crest and dunes, and in coral gravel flats, around the east coast and southeast peninsula coast, the north and Paris peninsula, and on lagoon islands (MCG map). Occasional in open, sandy sites in herblands and scrublands to the east of Main Camp and Captain Cook Hotel in 1996, and found once in 1997. Despite a half an hour search in the 1996 sites in 2006, only 
seen once there. No records since then.

Recorded: C\&B 1924; SFC 1934; F\&M 1936; MDG 1958-1959; CRL 1964; RNJ 1965; MCG 19791982; RWH 1982, specimen 1205[AT!] at BISH; LLW 1982; RRT 1996, 2006; HLJ 1997

Voucher Specimen: USP27336

Voucher Photographs: DPKR2356, 2357, 2358, 2359a

Eleusine indica (L.) Gaertn.

Common Names: Wiregrass, goosegrass

Kiribati Name: te uteute ("grass" in general)

Status: Recent introduction. India; long naturalized in Old World.

Abundance: Abundant.

Remarks: First reported in the late 1950s in the north; still occasional in the 1980s, when found only around London, the airport, Dakota Strip and Poland (MCG map). Now occurs in often dense concentrations or colonies in gardens, near pig pens, waste places, roadsides and other ruderal habitats in all settlements, and along the road at Aeon Field. Young grass is eaten by pigs.

Recorded: MDG 1958-1959; DCH 1962; CRL 1964; RP 1977-1979; MCG 1979-1982; LLW 1982; RRT 1996, 2006; HLJ 1997; AT 2008, 2009

Voucher Specimens: AT X010 X029 X030 London

Voucher Photographs: DPKR0187, 0245, 2398a; AT20080424_01, AT20080424_02, AT20080424_03, AT20080424_04,AT20080427_23

Eragrostis ciliaris (L.) R. Br.

Common Names: Stinkgrass, lovegrass

Kiribati Name: te uteute ("grass" in general)

Status: Recent introduction. Tropical America?

Abundance: Rare.

Remarks: Collected once, along roadside near the Captain Cook Hotel employee residences in August 1982, but not seen since.

Recorded: LLW 1982, Wester specimen 2121[AT!]

Eragrostis paupera Jedwabn.

Synonyms: E. whitneyi Fosb. (of most authors on Kiritimati). Includes E. falcata (Gaud.) Gaud. (of Christophersen 1927).

Common Name: Lovegrass

Status: Apparently indigenous. Pacific islands.

Abundance: Uncommon.

Remarks: Small annual, first reported in 1924, as a pioneer on sand flats in the lagoon, in places within reach of high tide. Several collected in the 1930s. Very common inland on lagoon islets and southeast peninsula, in the 1980s (MCG map), but the only more recent observations were in 1997, when it was only found in patches on smaller lagoon islets. Probably recently overlooked.

Recorded: C\&B 1924; SFC 1934; F\&M 1936; LWB 1945; CRL 1964; RP 1977-1979; MCG 1979-1982; HLJ 1997

Eragrostis scabriflora Swallen

Synonym: E. pilosa (L.) Beauv. (in Wester, 1985). Clayton and Snow (2010) have determined "E. pilosa" specimens from the Northern Lines, including Kiritimati specimens Hobdy 1194 (Jan 1982) and Wester 2150, 2110, to be E. scabriflora (N. Snow, pers. comm.; BISH).

Status: Recent introduction. Tropical America?

Abundance: Uncommon.

Remarks: First reported in 1982, when found to be common at the airport, less so at Banana and a single tussock in London. Seen again in 1996 and 2006 near airport. Common at the airport in 2008- 
2009; common in open sandy areas near the wharf in London, and in patches at Banana, in 2009. A few plants still visible at the airport and London wharf after a dry spell in early 2011. Has apparently not spread far from original sites of introduction.

Recorded: RWH 1982, specimen 1194[AT!] at BISH; LLW 1982; RRT 1996, 2006; AT 2008, 2009, 2011

Voucher Specimens: AT X011, X012 wharf in London, X031 Airport

Voucher Photographs: DPKR0339, 0340, 1928b; AT20080423_02, AT20080423_05, AT20090917_02

Eragrostis tenella (L.) Beauv. ex Roem. \& Schult.

Synonym: Eragrostis amabilis auct. non (L.) Wight \& Arn. ex Hook. \& Arn.

Common Names: Lovegrass, Japanese lovegrass

Kiribati Name: te uteute ni aine ("women's or female grass")

Status: Recent introduction. Old World.

Abundance: Common.

Remarks: First reported at London and a copra camp to the north of London, in 1924. Has since become common, in scattered dense clusters in sandy areas inland from the coast, around buildings, along paths and roadsides in all villages, and in copra camps, port areas, waste ground, old airfields and other ruderal places elsewhere (MCG map). Inflorescences used in garlands; children attach inflorescences to sticks to chase flies.

Recorded: C\&B 1924; Fosberg 1936 (Fosberg spec. 13229 cited in Chock and Hamilton, 1962); MDG 1958-1959; MCG 1979-1982; LLW 1982; RRT 1996, 2006; HLJ 1997; AT 2008, 2009, 2011

Voucher Specimen: AT X024 London

Voucher Photographs: DPKR0691, 0710, 1239b, 1928a; AT20080424_09

Eustachys petraea (Sw.) Desv.

Kiribati Name: te uteute ("grass" in general)

Status: Recent introduction. Tropical America.

Abundance: Occasional in 1996-2006, common 2008-2012.

Remarks: Seen near the airport in 1996 and since. In 2006-2011 a common weed along roadsides in the settlements from London to Banana, abundant in and near London and progressively less common towards the north. Also found to be one of the most common adventive recentlyintroduced grasses in Tarawa and other atolls of the Gilbert Islands in 2002 (RRT, pers. obs.).

Recorded: RRT 1996, 2006; AT 2008, 2009, 2011, 2012

Voucher Specimens: AT X032 London, X033 Airport

Voucher Photographs: DPKR1657, 1658; AT20080424_10

Lepturus repens (G. Forst.) R. Br.

Common Name: Beach bunch grass

Kiribati Names: te uteute ("grass" in general), kerotin (= "kerosene," because it is so inflammable when dry)

Status: Indigenous. Pacific islands.

Remarks: Since first reported (Bennett's (1840) "short and rigid grass" was probably this species), always regarded as very abundant throughout the island (MCG map). Perennial, in clusters, forming tufts or sometimes more of a creeping plant, spreading by stolons. Found on sand and silt among strand vegetation on ocean and lagoon shores. Common on calcareous hardpans and betterdrained areas surrounding saltpans and inland from the inner lagoon and landward from hypersaline ponds. Often the most dominant plant in coastal and inland sandy areas, open scrublands and in interior herblands on parts of Cook Island, Motu Tabu, Motu Upua and Ngaon te Taake islets. Common as scattered individuals colonising recently deposited sand and fine rubble ridges and terraces on wave-deposited beaches, such as on Motu Upua. The dominant species in extensive "meadows" and herblands found just north of Tabwakea village, in fairly 
extensive areas in the center of the northern part of the island between Northwest Point and Cape Manning, a large area extending to the east of Cassidy Airport toward Northeast Point, areas south of Aeon Field and near Dakota Strip and extending to the west on the southeast peninsula, the area west of Tahiti and south of Te Kaba (New Zealand Airfield), and the Poland plains, just north of Poland. Important sand-binding species that protects and stabilises beaches, sand dunes and sand hills. Important habitat for many ground-nesting seabirds and for the snake-eyed skink Cryptoblepharus eximius, which is quite common in sandy areas north and southeast of Poland.

Recorded: FDB 1835 (?); C\&B 1924; SFC 1934; F\&M 1936; FLH 1957; MDG 1958-1959; DCH 1962; CRL 1964; RNJ 1965; RP 1977-1979; MCG 1979-1982; RWH 1982; LLW 1982; RRT 1996, 2006; HLJ 1997; AT 2008, 2009, 2011, 2012

Voucher Specimen: AT X039 north of London

Voucher Photographs: DPKR0023a, 0024a, 0025a, 0074, 0391, 0407c, 0556a, 0593a, 0607a, 0859a, 0864a, 0868b, 0903b, 0966, 0967, 0983, 1107b, 1167a, 1171a, 1347a, 1350a, 1353a, 1361a, 1381a, 1382a, 1383a, 1422a, 1445a, 1446a, 1457b, 1460a, 1496, 1539, 1642a, 1721a, 1827a, 1855a, 1878a, 1879, 1882a, 1939, 2224, 2250b, 2290a; AT20080423_17, AT20080423_18

Melinis repens (Willd.) Zizka

Synonyms: Rhynchelytrum repens auct. non (Willd.) Hubb.; Tricholaena rosea Nees

Common Names: Natal grass, Natal red top

Status: Recent introduction. South Africa.

Abundance: Uncommon.

Remarks: Erect perennial grass bearing dark red or purplish feathery flowers, which fade to silver-pink when old. Recorded in the late 1970s, then found again in 2006, in a large clustered population in an open lot just to the west of the terminal at the airport. Not found there since.

Recorded: RP 1977-1979; MCG 1979-1982; RRT 2006

Voucher Photographs: DPKR2322a, 2323a, 2324, 2326a

Panicum maximum Jacq.

Common Name: Guinea grass

Status: Recent introduction. Tropical Africa.

Abundance: Extirpated.

Remarks: Identified as P. barbinode Trin. by S \& F 1934. Only found once, as an adventive in a garden in October 1934. An early introduction as a fodder grass into many Pacific islands.

Recorded: SFC 1934; Fosberg 1936, specimen 12170[AT!] at BISH

\section{Saccharum officinarum L.}

Common Name: Sugar cane

Kiribati Name: te kai tioka ("sugar tree/plant")

Status: Recent introduction. New Guinea and Tropical Asia.

Abundance: Uncommon.

Remarks: Seen planted in houseyard gardens in Tabwakea and London in 1996 and in most settlements in 2006. Not seen anywhere in 2008-2009, although reportedly still grown by a few people in Tabwakea, but used only for chewing (T. Teraira and R. Bebe, pers. comm.). Young plant in cultivation at the Agricultural Station in 2011.

Recorded: RRT 1996, 2006; AT 2011

Voucher Photographs: DPKR0223, 0360, 1280a, 1287; AT20110309_06

\section{Zea mays L.}

Common Names: Maize, corn

Kiribati Name: te kon ("corn")

Status: Recent introduction. Americas. 
Abundance: Rare.

Remarks: Two juvenile plants seen in two gardens in London in 1996. Seedlings in cultivation at the Agricultural Station in 2011, and reportedly grown by a few people in Tabwakea (T. Teraira, pers. comm.).

Recorded: RRT 1996; AT 2011

\section{DICOTYLEDONAE (DICOTYLEDONS)}

\section{ACANTHACEAE (ACANTHUS FAMILY)}

Pseuderanthemum carruthersii (Seem.) Guill.

Common Name: False eranthemum

Kiribati Names: te iaro, te iamaii

Status: Recent introduction. Melanesia?

Abundance: Occasional.

Remarks: Planted ornamental shrub and hedge plant, first noticed about 1980, when the variety was not recorded. More recently, two distinctive varieties recorded (see following accounts).

Recorded: MCG 1979-1982; LLW 1982

Pseuderanthemum carruthersii (Seem.) Guill. var. carruthersii

Common Name: False eranthemum

Kiribati Names: te iaro, te iamaii

Status: Recent introduction. Melanesia?

Abundance: Uncommon.

Remarks: Planted ornamental shrub and hedge plant. Seen at the school to the north of Tabwakea and in houseyard gardens in 1996 and 2006. Flowers used in garlands; flexible stems are used to make fishing rods for catching ninimai (Gerres sp.) and other small fish.

Recorded: RRT 1996, 2006

Pseuderanthemum carruthersii (Seem.) Guill. var. atropurpureum (Bull) Fosb.

Common Names: Purple false eranthemum, false face

Kiribati Name: te iaro

Status: Recent introduction. Melanesia?

Abundance: Occasional.

Remarks: Planted ornamental shrub and hedge plant. Found in London, Tabwakea and other villages since 1996, and at the Captain Cook Hotel in 2008-2009.

Recorded: RRT 1996, 2006; AT 2008, 2009, 2011

Voucher Photographs: DPKR0165, 0842, 0843, 0844, 1190, 1655, 1656; AT20080427_35, AT20080427_36, AT20090922_22

Pseuderanthemum reticulatum (Bull) Radlk.

Synonym: Pseuderanthemum carruthersii ( Seem.) Guill. var. reticulatum (Bull) Fosb.

Common Name: Yellow-vein pseuderanthemum

Kiribati Name: te iaro

Status: Recent introduction. Melanesia?

Abundance: Uncommon.

Remarks: Planted ornamental shrub and hedge plant with yellowish upper leaves with a netted variegated pattern. Seen in London, Tabwakea and Banana in 1996. 
Recorded: RRT 1996

Voucher Photographs: DPKR0203, 0204, 1650, 1651, 1652

\section{AIZOACEAE (CARPETWEED OR ICEPLANT FAMILY)}

Sesuvium portulacastrum L. var. griseum Deg. \& Fosb.

Kiribati Names: uteute ntari, te boi ntari

Status: Indigenous. Pantropical and found in most of Melanesia, Polynesia and Micronesia.

Remarks: Widespread in the 1980s (MCG map). Common in wetter saline sites on the shores bordering the tidal flats of the lagoon, around hypersaline ponds, and in low-lying, sparsely vegetated areas that are flooded during times of heavy rain. Common in dense populations or mats bordering tidal lagoon shores and on sand bars of the main island and lagoon islets such as Motu Upua, Motu Tabu and Ngaon te Taake; on Motu Tabu, an extensive area surrounding the north side of the Pisonia grove and extending onto the small peninsula on the north coast. Also found growing on levees and sandy mudflats surrounding artificial excavated (originally for brine shrimp) milkfish ponds to the west of the road to the southeast peninsula. Extensive monospecific meadows are found on the supratidal flats to the east of Poland.

Recorded: THS 1874; C\&B 1924; SFC 1934; MDG 1958-1959; DCH 1962; CRL 1964; RNJ 1965; MCG 1979-1982; LLW 1982; RRT 1996, 2006; HLJ 1997; AT 2008, 2009, 2011, 2012

Voucher Specimen: AT X044 central area

Voucher Photographs: DPKR0324, 0325a, 0327, 0468, 0491, 0510, 0546a, 0550a, 0551, 0566, 0654, 0657b, 2187b; AT20080423_25, AT20080423_31, AT20080426_85

\section{AMARANTHACEAE (AMARANTH FAMILY)}

Amaranthus dubius Mart. ex Thell.

Common Names: Spleen amaranth, amaranth, pigweed

Kiribati Names: te mota, te moota

Status: Recent introduction. Tropical America.

Abundance: Common.

Remarks: Weed around houses, along roadsides, in waste places and other ruderal sites in 1996 and 2006. By 2008-2009, had become seasonally common in all villages from London to Poland. Largely dies back and disappears in the dry season. Leaves commonly boiled or fried, as one of the few widely available green pot herbs on the island.

Recorded: RRT 1996, 2006; AT 2008, 2009, 2012

Voucher Specimen: AT X021 London

Voucher Photographs: DPKR0045, 0054, 0251, 0281, 0283a, 0820, 1261, 2017; AT20080430_00, AT20080430_01, AT20080430_02, AT20080430_03, AT20080430_04

\section{Amaranthus tricolor L.}

Common Names: Joseph's coat, Chinese spinach

Kiribati Names: te mota, te moota, te moota uraura

Status: Recent introduction. Tropical Asia.

Abundance: Rare.

Remarks: Planted ornamental or potherb with dark purple leaves seen in houseyard garden in north London in 2006. Some records currently listed under A. dubius could also be the green-leaved edible variety of $A$. tricolor.

Recorded: RRT 1996, 2006

Voucher Photographs: DPKR2453, 2454, 2455 


\section{ANACARDIACEAE (CASHEW OR RHUS FAMILY)}

\section{Mangifera indica $\mathrm{L}$.}

Common Name: Mango

Kiribati Name: te manko

Status: Recent introduction. Indo-Burma.

Abundance: Rare.

Remarks: A single mature tree with one immature fruit seen in the southern section of Tabwakea village in 2006. The tree was still there in 2009, when it was about $6 \mathrm{~m}$ tall and bearing a light fruit crop. Also in 2006, a small seedling seen planted in a container in Banana.

Recorded: RRT 2006; AT 2009

Voucher Photographs: DPKR1207, 2426, 2427, 2428; AT20090922_51

\section{ANNONACEAE (CUSTARD APPLE FAMILY)}

\section{Annona cf. squamosa L.}

Common Name: Red sugar apple

Status: Recent introduction. Tropical America.

Abundance: Rare.

Remarks: Small tree about $1.5 \mathrm{~m}$ high seen in one houseyard garden in London in 2006. Said to be " $A$. domestica" which is probably a red cultivar of A. squamosa.

Recorded: RRT 2006

Voucher Photographs: DPKR0839, 0840, 0841

\section{Apocynaceae (Dog-BAne FAMILY)}

Catharanthus roseus (L.) G. Don

Synonyms: Vinca rosea L.; Lochnera rosea (L.) Reich.

Common Name: Madagascar periwinkle

Kiribati Name: te buraroti, te bunonon $(\mathrm{N})$

Status: Recent introduction. Madagascar.

Abundance: Common.

Remarks: Planted ornamental first recorded 1996, in houseyard gardens in most settlements, and around government and business premises. Flowers used in garlands. Light red, pink, purple-pink and white cultivars present.

Recorded: RRT 1996, 2006; AT 2008, 2009, 2011, 2012

Voucher Photographs: DPKR0146a, 0182, 0186a, 0195, 0795c, 1224a, 1262, 1270, 1294a, 1991, 2473; AT20080427_05

\section{Nerium oleander L.}

Common Name: Oleander

Kiribati Name: te orian

Status: Recent introduction. Asia.

Abundance: Occasional.

Remarks: First recorded about 1980, in gardens. Seen planted outside government buildings on the outskirts of London, and in a houseyard garden in London in 1996. In 2006-2011, occasional as a planted ornamental shrub in houseyard gardens and around buildings in all villages.

Recorded: MCG 1979-1982; LLW 1982; RRT 1996, 2006; AT 2008, 2009, 2011, 2012

Voucher Photographs: DPKR0243b, 0796, 1236, 1985, 1986, 1993c; AT20080427_22 


\section{Plumeria obtusa L.}

Common Names: White frangipani, Singapore plumeria

Kiribati Name: te meria

Status: Recent introduction. Tropical America.

Abundance: Common.

Remarks: Planted ornamental tree since at least 1982. Seen in houseyard gardens in Tabwakea and London in 1996 and in all settlements and around government buildings in 2006-2011. The more common Plumeria in Banana. Flowers used for making garlands and leis, and for scenting coconut oil.

Recorded: LLW 1982; RRT 1996, 2006; AT 2008, 2009, 2011, 2012

Voucher Photographs: DPKR0114, 0151, 0785, 1231b, 2413, 2433, 2434, 2466; AT20080426_02

\section{Plumeria rubra L.}

Common Names: Frangipani, plumeria, temple tree

Kiribati Name: te meria

Status: Recent introduction. Tropical America.

Abundance: Common.

Remarks: Planted ornamental tree since at least 1982. In houseyard gardens in Main Camp, Tabwakea and London in 1996 and in all settlements in 2006-2011. Flowers used for making garlands and leis, and for scenting coconut oil.

Recorded: MCG 1979-1982; LLW 1982; RRT 1996, 2006; AT 2008, 2009, 2011

Voucher Photographs: DPKR0766, 0767, 0811, 0812, 0813, 1321, 1917, 1918

\section{Araliaceae (PANax Family)}

Polyscias filicifolia (C. Moore) L.H. Bailey

Common Name: Fern-leaf aralia

Status: Recent introduction. SE Asia.

Abundance: Rare.

Remarks: Cuttings in cultivation in the Agricultural Station in 2008. Hedge plants seen in a garden in Banana in 2009.

Recorded: AT 2008, 2009

Voucher Photograph: AT20080428_12

Polyscias fruticosa (L.) Harms

Common Name: Parsley panax

Kiribati Name: te toara, te ngeri, te kaimamara

Status: Recent introduction. India to western Polynesia.

Abundance: Rare.

Remarks: A single mature plant about $1.6 \mathrm{~m}$ high seen planted next to the front door in a houseyard garden in Banana in 2006.

Recorded: RRT 2006

Voucher Photograph: DPKR1220, 1221

Polyscias guilfoylei (Cogn. and March.) Bailey

Common Name: Panax

Kiribati Name: te toara (S. Gilbert Islands), te batatara (N. Gilbert Islands)

Status: Recent introduction. Melanesia to S. Polynesia.

Abundance: Common.

Remarks: Seen in houseyard gardens in all settlements as an ornamental shrub, which is commonly planted as a hedge or living fence along borders of household allotments. Fragrant, variegated 
white and green leaves used in garlands and for body oranmentation for dances.

Recorded: RRT 1996, 2006; AT 2009, 2011

Voucher Photographs: DPKR0138, 0756b, 1288b, 1291b, 2401, 2402

Polyscias scutellaria (N.L. Burman) Fosberg

Common Name: Dinner plate aralia

Status: Recent introduction. Melanesia.

Abundance: Rare.

Remarks: Cuttings in cultivation in the Agricultural Station in 2008, and one small shrub there in 2009 and 2012; quite old, heavily pruned shrubs found in a garden in Banana in 2009.

Recorded: AT 2008, 2009, 2012

Voucher Photographs: AT20080428_10, AT20090922_25

\section{ASCLEPIADIACEAE (MILKWEED FAMILY)}

\section{Cryptostegia madagascariensis Bojer}

Common Name: Madagascar rubber vine

Status: Recent introduction. Madagascar.

Abundance: Rare.

Remarks: Ornamental shrub with light purple flowers seen planted in three places in 2006-2012: near a government building in the main port settlement in London; one at the Captain Cook Hotel; and one in a garden in Banana.

Recorded: RRT 2006; AT 2008, 2009, 2011, 2012

Voucher Specimen: AT X007 Captain Cook Hotel

Voucher Photographs: DPKR0111, 0112, 1193, 2474; AT20080427_34, AT20090922_07, AT20090922_09, AT20090922_11, AT20090922_12, AT20090922_28

\section{ASTERACEAE (ASTER OR COMPOSITE FAMILY)}

Bidens pilosa $\mathrm{L}$.

Common Names: Cobbler's peg, Spanish needles, beggars tick, burr-marigold

Status: Recent introduction. Tropical America; now a pantropical weed.

Abundance: Uncommon.

Remarks: First noticed about 1980, when found near Southeast Point and scattered in one area of islets and strips of land to the northwest of Carver Way (MCG map). One plant seen near Aeon Field airstrip in 1997. In 2006, seen only at one location: in the parking lot next to Emanuera Catholic Church, London, and in ruderal vegetation behind the church. Perhaps more common than the few recent records suggest, with appearance depending on rainfall.

Recorded: MCG 1979-1982; HLJ 1997; RRT 2006

Voucher Photographs: DPKR1994, 2009

Chromolaena odorata (L.) King and Robinson.

Common Names: Siam weed, Jack in the bush

Status: Recent introduction. Tropical America.

Abundance: Rare.

Remarks: A group of small plants, about $30 \mathrm{~cm}$ high, seen at the staging area for the stockpiling of salvaged machinery and metallic waste near the main wharf in 2006. Probably introduced in that year, as part of the salvage operation to clean up scrap from the nuclear testing era. Not seen in 2008-2012.

Recorded: RRT 2006 
Voucher Specimen: USP2K02609

Voucher Photographs: DPKR0055, 0056, 0059, 0060

Cosmos sulphureus Cav.

Common Name: Cosmos

Status: Recent introduction. Mexico.

Abundance: Rare.

Remarks: Annual ornamental plant seen in one home garden in London in 2006.

Recorded: RRT 2006

Voucher Photographs: DPKR0793, 2297

Cyanthillium cinereum (L.) H. Rob

Synonym: Vernonia cinerea (L.) Less.

Common Name: Ironweed

Status: Recent introduction. Tropical Asia.

Abundance: Common.

Remarks: First found at the settlements and copra camps, in 1924. In the early 1980s reported along roads and around settlements (Wester 1985; MCG map). Now a weed of houseyard gardens, roadsides, waste places, pig pens and ruderal sites in all settled areas. Virtually disappears during dry spells: after a three-month dry period in early 2011 , only found at the airport.

Recorded: C\&B 1924; MCG 1979-1982; LLW 1982; RRT 1996, 2006; AT 2008, 2009, 2011

Voucher Specimen: AT X046 Airport

Voucher Photographs: DPKR0044a, 0148, 1234b, 2345, 2462

\section{Gaillardia x grandiflora}

Common Names: Hybrid gaillardia, blanket flower, Indian blanket

Status: Recent introduction. Central and Western United States.

Abundance: Rare.

Remarks: Planted ornamental in one houseyard garden in Port Settlement in London in 2006.

Recorded: RRT 2006

Voucher Photographs: DPKR0273, 0274

Helianthus annuus L.

Common Name: Sunflower

Status: Recent introduction. Western United States.

Abundance: Rare.

Remarks: Seen planted in a food garden in Banana village in 1996 and 2006.

Recorded: RRT 1996, 2006

\section{Lactuca sativa L.}

Common Name: Lettuce

Status: Recent introduction. Southern Europe and western temperate Asia.

Abundance: Rare.

Remarks: A number of mature plants seen in a houseyard vegetable garden in Banana in 2006. The plants all seemed to be the Romaine or Cos cultivar.

Recorded: RRT 2006

Voucher Photographs: DPKR1206, 1208, 1209b, 1211a

Pluchea carolinensis (Jacq.) G. Don

Synonyms: Pluchea odorata (L.) Cass; P. symphytifolia (Mill.) Gillis

Common Names: American pluchea, shrubby fleabane, sourbush 
Kiribati Name: te kai kari (“curry plant")

Status: Recent introduction. Tropical America.

Abundance: Common.

Remarks: First recorded in 1958 near military sites in the north, and possibly introduced by American troops during or after World War II. Reported to form dense stands in disturbed sites in the 1960s, including around London, Main Camp and near Poland (Jenkin and Foale, 1968; CRL specimens [AT! ] at BISH). In the 1980s, found throughout the north from London to the airport, in the Poland area and with scattered records in the southeast near Aeon Field (MCG map). May have declined since then. Recorded in London in 1996 and near Poland in 1997. In 2006-2009, still common in waste places, open lots and houseyard gardens, where occasionally planted as part of hedges and along boundaries around houses; present in all settlements but less common in London than Tabwakea. Adventive and spreading in roadside scrubland between London and Tabwakea, though not as numerous there as P. indica. In 2008-2009, appeared more invasive in open grassland and scrub both north and southeast of Poland and around the site of the old New Zealand Airfield, but present in these areas as scattered individuals rather than dense thickets; in March 2011 after a dry spell of about three months, many of these bushes appeared dead or severely stressed, whereas native shrubs in the same area were not so affected.

Recorded: JPG 1958; MDG 1958-1959; DCH 1962; CRL 1964; WAS 1965; RNJ 1965; MCG 1979 1982; LLW 1982; RRT 1996, 2006; HLJ 1997; AT 2008, 2009, 2011, 2012

Voucher Specimens: AT X042 X043 London

Voucher Photographs: DPKR0057, 0358, 0359a, 0775, 1226b, 1227b, 1247, 1649, 1912a, 2294a, 2407; AT20080426_02, AT20080426_04

Pluchea x fosbergii Cooperider \& Galang

Status: Recent introduction.

Abundance: Occasional.

Remarks: Hybrid of $P$. indica and P. carolinensis, reportedly frequent in places where both parents occur. First reported in 1964, near barracks at the north end of the island (Main Camp). Locally common weed of roadsides and waste places in London in 2006; in 2009, common in waste places in and north of London, including some large dense patches.

Recorded: CRL 1964; RRT 1996, 2006; AT 2009

Voucher Photographs: DPKR0321, 1245

Pluchea indica (L.) Less.

Common Name: Indian pluchea

Kiribati Name: te aronga??

Status: Recent introduction. Southern Asia.

Abundance: Abundant.

Remarks: First recorded near the airport in 1962 and probably introduced accidentally during military operations during or after the WWII. Up to the 1980 s, much less common than $P$. carolinensis and only found in London, Main Camp and near the airport (MCG map). Has since become more widely distributed, and in places is much more common than $P$. carolinensis. Now a locally abundant weed of roadsides and waste places in and around all settlements and deliberately planted as hedges in many houseyard gardens in London, Tabwakea and Banana. Many large, naturalized populations in open lots and around the outskirts of these settlements, especially between London and Tabwakea, in 2006-2012. Where invasive, often forms dense stands. Also dominant in the coastal vegetation along the shores of the small inner lagoon north of the London peninsula.

Recorded: DCH 1962; CRL 1964-1965, specimens [AT!] at BISH; WAS 1965; MCG 1979-1982; LLW 1982; RRT 1996, 2006; AT 2008, 2009, 2011, 2012

Voucher Photographs: DPKR0058, 0061, 0136, 0139, 0142, 0240a, 0306a, 0322, 0330a, 1227a, 1246, 
2294b, 2295a, 2320; AT20080424_02, AT20080424_11

\section{Sonchus oleraceus L.}

Common Name: Sow thistle

Status: Recent introduction. Pantropical weed of Eurasian or African origin.

Abundance: Rare.

Remarks: One record, of a single adult plant bearing flowers and ripe seed-heads, surrounded by a few young seedlings, growing in coral gravel in the baggage unloading area at the arrivals terminal of Cassidy Airport in March 2011; most likely brought in as a seed adhering to a passenger's baggage. All the plants were pulled up and burnt (one voucher specimen retained), and not seen there (or elsewhere) in 2012.

Recorded: AT 2011

Voucher Specimen: AT X002

\section{Tagetes erecta L.}

Common Name: Marigold

Kiribati Name: te merikora

Status: Recent introduction. Mexico.

Abundance: Uncommon.

Remarks: Planted ornamental annual in houseyard gardens in London, Tabwakea and Main Camp. Replanted from year to year using imported packaged seeds.

Recorded: RRT 1996, 2006

Voucher Photographs: DPKR1310, 1311

Tridax procumbens L.

Common Name: Wild daisy, coat buttons

Status: Recent introduction. Tropical America.

Abundance: Common.

Remarks: First noticed about 1980, with a "local population" found near Captain Cook Hotel in 1982. Recorded in London in 1996 and since then seen in all settlements, around buildings and around the airport, port and main jetty, where it is a weed of roadsides, open lots, houseyard gardens, waste places, ruderal sites and occasionally near beaches.

Recorded: MCG 1979-1982; LLW 1982; RRT 1996, 2006; AT 2008, 2009, 2011, 2012

Voucher Photographs: DPKR0119, 1987; AT20080424_07

Verbesina encelioides (Cav.) B. \& H ex Gray

Common Name: Golden crown-beard

Status: Recent introduction. Mexico and the southwestern United States.

Abundance: Rare, possibly extirpated.

Remarks: First recorded as a planted ornamental in front of the Bachelor Officers' Quarters in London in 1965, and found as a volunteer in waste places in London in 1982. Not seen since and perhaps died out.

Recorded: CRL 1965, specimen 3439[AT!] at BISH; LLW 1982; Wester 1982, 2113[AT!] at BISH

\section{Zinnia violacea Cav.}

Common Name: Zinnia

Kiribati Name: te tinia

Status: Recent introduction. Mexico.

Abundance: Rare.

Remarks: Planted ornamental annual in Tabwakea and London.

Recorded: RRT 1996, 2006 


\section{BARRINGTONIACEAE (BARRINGTONIA FAMILY)}

Barringtonia asiatica (L.) Kurz

Common Name: Fish-poison tree

Status: Indigenous to the region but probably a recent introduction to Kiritimati. Madagascar to west Polynesia.

Abundance: Rare, probably extirpated.

Remarks: Found in London about 1980 but not seen since and probably died out.

Recorded: MCG 1979-1982; additional details for this record provided by M. C. Garnett (pers. comm.)

\section{BIGNONIACEAE (BIGNONIA FAMILY)}

Spathodea campanulata Beauv.

Common Name: African tulip tree

Status: Recent introduction. Tropical Africa.

Abundance: Rare.

Remarks: A single mature tree about $6 \mathrm{~m}$ tall planted in a garden in London. Reportedly flowers every year.

Recorded: RRT 2006, AT 2008

Voucher Photographs: DPKR2380, 2381, 2385, 2386, 2459

Tecoma stans ( L.) Juss. ex HBK.

Common Name: Tecoma, yellow elder

Kiribati Name: nei karairai ("Lady Karairai")

Status: Recent introduction. Tropical America.

Abundance: Occasional.

Remarks: Planted ornamental shrub in houseyard gardens in London, Tabwakea, Banana and Poland and around government buildings. In London, some apparently self-sown seedlings noted not far from a parent tree in 2008, and others across the road from another parent in 2011. Bright yellow flowers used in making garlands and headbands.

Recorded: RRT 1996, 2006, AT 2008, 2009, 2011, 2012

Voucher Photographs: DPKR0270, 0846, 1265b, 1288a; AT20080427_09, AT20080427_10

\section{BORAGINACEAE (HELIOTROPE OR BORAGE FAMILY)}

\section{Cordia sebestena L.}

Common Names: Geiger tree, sebesten plum

Kiribati Name: te kanawa ni Mainiku (in the Kiribati language the "Cordia subcordata from the east")

Status: Recent introduction. Caribbean.

Abundance: Occasional.

Remarks: First reported in the late 1970s, "established at a couple of spots along the beach crest between London and the Northwest Point" (R. Perry, in litt.), and around 1980 planted as an ornamental with scarlet flowers in London. In 1996 and 2006, found as an ornamental tree in houseyard gardens in London, Tennessee, Tabwakea and Banana; by 2009, commonly planted in these villages.

Recorded: RP 1977-1979; MCG 1979-1982; LLW 1982; RRT 1996, 2006; AT 2009, 2011, 2012; additional details for this record provided by L. L. Wester (pers. comm.)

Voucher Photographs: DPKR0254, 0255, 0256, 0695, 0744, 0791b, 1231c, 2405; AT20090922_01

Cordia subcordata Lam.

Common Name: Sea trumpet, island walnut, beach cordia 
Kiribati Name: te kanawa

Status: Indigenous to the region, but probably a deliberate introduction to Kiritimati, perhaps from the wetter Line Islands. Indian Ocean to Hawaii.

Abundance: Occasional.

Remarks: First recorded in the 1970s, when it was considered by RP as introduced, although listed as native by MCG, whose map shows it present only around London, Tabwakea and Northwest Point. Still most common in cultivation, and present in all settlements including Poland, but also found rarely in strand forest on coastal and lagoon sides, including on the Paris peninsula, and in some inland sites, such as near the water pumping stations to the west of the Captain Cook Hotel and on Aeon Field. One large grove near London, where it is also commonly planted in houseyard gardens and is one of the main street trees; also the main tree planted by the sports ground opposite Emanuera Catholic Church in London. One tree in the coastal vegetation on the northwest coast of Motu Upua; one large tree to the west of the Pisonia grove and a couple of trees in the coastal herbaceous vegetation on the north and south ends of Motu Tabu. A sacred tree that is the totem of some kinship groups in the Gilbert Islands and mentioned in many legends; wood is valued, especially for carving, bows and sterns of canoes and fishnet floats; flowers used in garlands; leaves added to compost for taro pits cultivation; twigs and bark used for medicine; branches of shrubby trees for fishing poles; inner bark reportedly used, in the past, for a girdle for pregnant women to give them magical protection.

Recorded: RP 1977-1979; MCG 1979-1982; RRT 1996, 2006; AT 2008, 2009, 2011

Voucher Photographs: DPKR0160, 0308, 0309, 0352a, 0421, 0422d, 0539, 0657a, 0684, 0727b, 0728, 0741, 0760, 0899, 0900, 1099, 1100, 1101, 1102a, 1301, 1641, 1887, 1907, 1971b, 1974, 1976; AT20080424_14, AT20080427_15

Heliotropium anomalum Hook. \& Arnott Synonym: Heliotropium curassavicum of Bennett (1840)

Common Name: Beach heliotrope

Kiribati Name: te ren rinano ("low-growing or small ren"; ren = Tournefortia)

Status: Indigenous. Ryukyu Islands and throughout Micronesia to the Tuamotus, Austral and Hawaiian Islands, mainly on limestone islands and sandy beaches.

Abundance: Abundant, and always regarded as common throughout the island (MCG map).

Remarks: Found in open sandy or rocky habitats in shrublands and herblands and on inner margins of beaches and shores of hypersaline ponds throughout the island. Often dominant on open gravelly areas in the SE and SW. Very common on Cook Island and Ngaon te Taake islets, especially in the rockier, drier sites. Also a dominant species in open shrublands, herblands and inner beach terraces on Motu Upua.

Recorded: FDB 1835; C\&B 1924; GPW 1924; SFC 1934; F\&M 1936; LWB 1945; WFC 1957; FLH 1957; JPG 1958; MDG 1958-1959; DCH 1962; RNJ 1965; RP 1977-1979; MCG 1979-1982; RWH 1982; LLW 1982; RRT 1996, 2006; HLJ 1997; AT 2008, 2009, 2011, 2012

Voucher Photographs: DPKR0422b, 0454b, 0594a, 0596b, 0599a, 0607b, 0642, 0969a, 1004a, 1017a, 1123, 1130, 1338a, 1343a, 1369a, 1370, 1404, 1454, 1455, 1504a, 1634, 1679a, 2225, 2257, 2258; AT20080426_05, AT20080426_06, AT20080426_25, AT20080426_43

\section{Heliotropium procumbens Mill.}

Common Name: Prostrate heliotrope

Status: Recent introduction. Tropical America.

Abundance: Occasional.

Remarks: In 2006, a rare roadside ruderal near one house in London. In 2008-2011, common in open waste places and roadsides in London, particularly near the wharf and surrounding areas, and apparently spreading very rapidly. In 2009 found near the government offices and bank on the northern outskirts of London. In 2011, still abundant after a dry period, when most other ruderals 
had died back. Mostly found as a procumbent herb but in places scrambles up hedges and fences to approximately $50 \mathrm{~cm}$ height.

Recorded: RRT 2006; AT 2008, 2009, 2011, 2012

Voucher Specimen: AT X036 London

Voucher Photographs: DPKR1296a, 1297; AT20080424_06, AT20080427_24

Tournefortia argentea L. f.

Synonym: Messerschmidia argentea (L. f.) M. Johnst.

Common Name: Heliotrope tree, beach heliotrope

Kiribati Name: te ren

Status: Indigenous. Indian Ocean to SE Polynesia.

Abundance: Abundant.

Remarks: First reported in 1835. In 1924, found on beach crests and dunes all around the island and in the NW interior. In the 1980s similarly found throughout most of the island but in the interior of the southeast peninsula only as scattered clumps (MCG map). The most abundant tree on the island and dominant in woodlands and small tree groves on both sandy and rocky substrate throughout. Forms coastal strand woodland, especially inland from wider, sandy beaches, such as along parts of the north coast; these woodlands grade into more open Tournefortia scrub and savannas. Seedlings and saplings are also a component on unstable, recently deposited sand and rubble dunes and terraces, such as those on the southeastern end of Motu Tabu. It is also the main tree on sand dunes such as Joe's Hill on the west coast and the Auvergne Sandhills east of Poland. Planted in and around villages in all parts of the island and protected as shade trees on beaches near villages and coastal tourist accommodation. In 2006, in many areas on the smaller, more exposed islets, such as Motu Upua, Motu Tabu and Cook Island, a large percentage of trees were dead, reportedly having died during the drought of the two previous years. Populations on these islands were healthy in 2008-2011. On islets, areas of Tournefortia are the main nest sites for black noddies, red-footed boobies and fairy terns. They also provide cover for ground-nesting tropicbirds, which commonly nest near the base of the main trunk, and are important as nesting and perching trees for frigate birds. Its wood is an important fuel; young leaves and growing tips used medicinally.

Recorded: FDB 1835; C\&B 1924; SFC 1934; F\&M 1936; LWB 1945; MDG 1958-1959; DCH 1962; CRL 1964; RNJ 1965; RP 1977-1979; MCG 1979-1982; LLW 1982; RRT 1996, 2006; HLJ 1997; AT 2008, 2009, 2011, 2012

Voucher Photographs: DPKR0047, 0090, 0091, 0093, 0096, 0103a, 0161, 0238b, 0384a, 0431, 0432, 0433, 0435, 0437a, 0440, 0472a, 0501b, 0515, 0519, 0562, 0567b, 0585, 0608b, 0652c, 0707, 0712b, 0855, 0859b, 0860, 0864b, 0874, 0903a, 0930c, 0931, 0932, 0937, 0939a, 0959, 0979b, 0981b, 0997a, 1000b, 1009, 1096, 1132, 1371b, 1445b, 1535, 1553, 1560, 1614, 1615, 1617, 1632, 1633a, 1738a, 1742a, 1761b, 1766b, 1781b, 1849a, 2032c, 2042a, 2059, 2222b, 2223, 2349, 2350a, 2352a, 2366a; AT20080423_13, AT20080423_14, AT20080423_15, AT20080423_16

\section{BRASSICACEAE (CABBAGE OR MUSTARD FAMILY)}

\section{Brassica chinensis L. var. chinensis}

Common Names: Chinese cabbage, Chinese white cabbage, pak choi

Kiribati Name: te kabiti n Tiaina ("Chinese cabbage")

Status: Recent introduction. Asia.

Abundance: Uncommon.

Remarks: Found planted in a number of houseyard food gardens in London, Tennessee, Tabwakea and Banana since 1996, and at the Agricultural Station in 2008 and 2012.

Recorded: RRT 1996, 2006; AT 2008, 2012 
Voucher Photographs: DPKR0750, 0752, 0784, 0799a, 1151, 1164a, 1274, 2013a, 2014;

AT20080428 00

Brassica x hybridus "Saladeer"

Common Name: Saladeer hybrid Chinese cabbage

Kiribati Name: te kabiti $n$ Tiaina ("Chinese cabbage")

Status: Recent introduction. Asia.

Abundance: Uncommon.

Remarks: Food plant in houseyard gardens in London and Banana in 1996 and 2006. The most popular and successful Chinese cabbage grown in the Gilbert Islands in the early 2000s (RRT, pers. obs.).

Recorded: RRT 1996, 2006

Voucher Photograph: DPKR1152

Brassica oleracea L. var. capitata L.

Common Names: English cabbage, head cabbage

Kiribati Names: te kabiti ni i-matang, te kabiti $n$ ingiriti

Status: Recent introduction. Europe.

Abundance: Uncommon.

Remarks: First reported in 1982, but present on Tabuaeran from the mid-19th century (Wester 1985).

Food plant in houseyard gardens in London and Banana in 1996, 2006 and thereafter, and at the Agricultural Station in 2008-2011.

Recorded: LLW 1982; RRT 1996, 2006; AT 2008, 2009, 2011

Voucher Photographs: DPKR0769b, 0827b, 1153, 2013b, 2015

Lepidium bidentatum Mont.

Synonym: L. owaihense Chamisso \& Schlechtendal (of Christophersen, 1927)

Common Name: Scurvy grass

Status: Indigenous. New Caledonia to east Polynesia and Hawaii.

Abundance: Occasional.

Remarks: In 1924, reported "sparingly around the settlements and in sheltered localities elsewhere."

Recorded intermittently from the 1920s to 1980 s, when it was found in several populations along the south coast, as well as in scattered places in the central lagoons area (MCG map), although not seen by Wester. Not found in 1996 or 2006, but in 2008-2009, found in scattered patches, mostly in association with Hedyotis romanzoffiensis, on gravelly coral substrate inland from the southwest coast, in the same area as the 1980s populations.

Recorded: C\&B 1924; CRL 1964; RP 1977-1979; MCG 1979-1982; RWH 1982; AT 2008, 2009

Voucher Specimen: AT X038 M Site, south coast

Voucher Photographs: AT20080426_63, AT20090919_02, AT20090919_04, AT20090919_07

Raphanus sativus L. var. longipinnatus Bailey

Common Names: White radish, daikon, Chinese or Japanese radish

Status: Recent introduction. E. Asia.

Abundance: Rare.

Remarks: A single plant seen in a container in a houseyard food garden in London in 2006.

Recorded: RRT 2006

Voucher Photograph: DPKR0828

CARICACEAE (PAWPAW FAMILy)

Carica papaya L.

Common Name: Pawpaw, papaya 
Kiribati Names: te babaia, te mwemweara

Status: Recent introduction. Tropical America.

Abundance: Common.

Remarks: Fruit tree first reported in 1962 "two cultivated trees near the airport." Since the 1980s, found planted in household gardens in all settlements and around some government buildings, and occasionally outside settled areas. Fruit fed to pigs; ripe fruit eaten raw and green fruit cooked as a vegetable.

Recorded: DCH 1962; MCG 1979-1982; LLW 1982; RRT 1996, 2006; AT 2008, 2009, 2011, 2012

Voucher Photographs: DPKR0156, 0183, 0186b, 0200, 0694, 0723, 0821b, 1161, 1281b, 1283b, 1883; AT20080427 11

\section{CASUARINACEAE (CASUARINA FAMILY)}

\section{Casuarina equisetifolia $\mathrm{L}$}

Common Name: Casuarina, she-oak

Kiribati Name: te burukam ("blue gum” by confusion with Eucalyptus), te katurina ("casuarina”)

Status: Recent introduction. Indian Ocean to Polynesia and Micronesia.

Abundance: Common.

Remarks: Planted at least since the 1960s and probably earlier, in villages, houseyard gardens and open lots, often as a windbreak or border planting in all the main settlements and around tourist resorts and other developments; in one guest house in London, pruned as topiary. Very large former plantation in the area of Main Camp and the Captain Cook Hotel, from where it is spreading outward, with seedlings along the roadside both east- and westward. Small woodlands in other places include just inland from the Port Settlement in London, near small lagoons north of the London peninsula, east of the Catholic Cathedral, on the ocean side of the London peninsula, and near Banana and around Poland. Some time after the 1970s, the JAXA Tracking Station complex was largely surrounded with windbreaks and trimmed boundary plantings of Casuarina. Occasional self-sown trees in sandy areas, and in 2011 seemed to have become a more aggressive invader in London, with seedlings and suckers growing prolifically in waste places, even in pavement cracks.

Recorded: CRL 1964; MCG 1979-1982; LLW 1982; RRT 1996, 2006; AT 2008, 2009, 2011, 2012

Voucher Photographs: DPKR0008a, 0009a, 0131, 0237b, 0291b, 0330b, 0331b, 0333b, 0334, 1309a, 1600, 1619, 1623, 1628, 1629, 1631, 1910, 2374, 2464; AT20080427_02, AT20110308_02, AT20120318_33

\section{Clusiaceae (MANGOSTEEN FAMiLy)}

\section{Calophyllum inophyllum L.}

Common Names: Portia tree, Alexandrian laurel, tomano, punai nut

Kiribati Name: te itai

Status: Indigenous to the region, but almost certainly introduced to Kiritimati. Tropical Africa to Micronesia and eastern Polynesia.

Abundance: Occasional. Only found in cultivation, and not reported before 1979.

Remarks: Individual trees planted in several gardens in London, Tabwakea and Banana and as street trees. One large tree in the cemetery outside London. Fine hard, fine-grained wood used in canoes, for canoe paddles and in traditional skindiving goggles; fruits used in children's games; kernels crushed and oil extracted, which is spread on sores; juice from roots mixed with water to treat headaches; also used to treat morning sickness, chicken pox and conjunctivitis; flowers used to perfume coconut oil; skin and outer flesh of the fruit can be eaten; flowers used in garlands.

Recorded: MCG 1979-1982; RRT 1996, 2006; AT 2008, 2009

Voucher Photographs: DPKR0177a, 0681, 1260, 2020, 2022, 2389, 2457; AT20080425_01 


\section{COMBRETACEAE (TERMINALIA FAMILY)}

\section{Terminalia catappa L.}

Common Names: Beach almond, Indian almond, Malabar almond

Kiribati Name: te kunikun (S. Gilbert Islands), te ntarine (N. Gilbert Islands)

Status: Aboriginal introduction to the region but probably only recently introduced to Kiritimati. Tropical Asia and Australia to Micronesia and West Polynesia.

Abundance: Common.

Remarks: Not reported before the 1970s. Medium to large semi-deciduous tree planted in household gardens, sometimes in drums, around buildings and as a street tree in all settlements. Some trees are of the variety of which whole unripe fruit can be eaten. Seeds are eaten raw; leaves used to wrap food for cooking in the earthen oven; wood sometimes used in houses.

Recorded: RP 1977-1979; MCG 1979-1982; LLW 1982; RRT 1996, 2006; AT 2008, 2009, 2011

Voucher Photographs: DPKR0110, 0311, 0319, 0680, 1981a, 1982, 2403; AT20110309_07, AT20110309 08

\section{Terminalia samoensis Rech.}

Synonym: Terminalia litoralis sensu auct. non Seem.

Common Name: Beach almond

Kiribati Name: te ukin

Status: Indigenous to the region but almost certainly introduced to Kiritimati. Indonesia to Micronesia and E Polynesia.

Abundance: Uncommon.

Remarks: Seen in one houseyard garden in Banana 1996. Found in a number of houseyard gardens in all settlements in 2006-2008. An important medicinal plant; roots used in treating mouth sores; part of plant used in a drink to treat coughing blood.

Recorded: RRT 1996, 2006; AT 2008

Voucher Photographs: DPKR0205, 0206, 0352b, 0690, 1272, 1903, 1904, 2432, 2466b

\section{CONVOLVUlACEAE (MORNING-GLORY FAMILY)}

Ipomoea batatas (L.) Lam.

Common Names: Sweet potato, kumara

Kiribati Name: te kumara

Status: Recent introduction. Tropical America.

Abundance: Occasional.

Remarks: Recorded in the 1970s. Seen in Banana, and planted in 50 gallon drums in London, in 1996.

Food plant in houseyard food gardens in all settlements in 2006, and at the Agricultural Station in $2008-2011$.

Recorded: RP1977-1979; MCG 1979-1982; RRT 1996, 2006; AT 2008, 2009, 2011

Voucher Photographs: DPKR0207b, 2019b, 2020b, 0356, 0747, 1267; AT20110309_01

Ipomoea macrantha R. \& S.

Common Names: Wild moon flower, white morning glory

Kiribati Name: te ruku

Status: Indigenous to the region but probably recently introduced to Kiritimati. Pantropical.

Abundance: Rare.

Remarks: Seen in a single houseyard garden in Tabwakea, in 1996, 2006-2012. Reported by the locals to have been introduced from Tabuaeran Island. In the Gilbert Islands, the stems and leaves are crushed in water and used as a shampoo and to treat lice, a preparation of the leaves is used to treat vomiting of blood, and reported to have aphrodisiacal properties. 
Recorded: RRT 1996, 2006; AT 2008, 2009, 2011, 2012

Voucher Specimen: AT X014 Tabwakea

Voucher Photographs: AT20080430_08, AT20090922_49, AT20110305_01, AT20110305_03

Ipomoea pes-caprae (L.) Sweet

Common Names: Goat-foot, beach morning glory

Kiribati Name: te ruku, te ruku ni maeao

Status: Indigenous to the region but probably introduced to Kiritimati. Pantropical.

Abundance: Uncommon.

Remarks: First recorded in 1996, and all populations found were probably planted, including an extensive population along the fence at the parking lot across from the Fisheries building at the main port in London, in an open field near the interior lagoon to the north of London, and in front of the Mormon Church just south of Tabwakea (all present 2006-2012). New plantings (i.e. since 2008) were found in 2011 on several plots in London. None seen on Kiritimati in its usual wild habitat throughout the Pacific, including on other Line Islands and the Gilbert Islands, where it grows as a vigorous creeping vine in coastal vegetation along the ocean and lagoon shoreline and occasionally somewhat inland. In London and Tabwakea, leafy stems used for waist garlands for dancing. Leaves and stems used to treat dandruff; stems mixed with coconut oil for treating boils; leaves mixed with water to treat dysentery; leaves washed in oil applied directly to wounds.

Recorded: RRT 1996, 2006; AT 2008, 2009, 2011

Voucher Photographs: DPKR0108, 0241a, 0242, 0243a, 0344, 0345, 0346, 0347, 2378, 2451, 2452;

AT20080427_21, AT20080427_22

\section{CUCURBITACEAE (MELON FAMILY)}

Citrullus lanatus (Thunb.) Matsum. and Tan.

Common Name: Watermelon

Kiribati Name: te meren ("melon")

Status: Recent introduction. Southern Africa.

Abundance: Uncommon.

Remarks: Food plant in household gardens in Banana and some other settlements in 1996, London in 2006, and at the Agricultural Station in 2008.

Recorded: RRT 1996, 2006, AT 2008

Voucher Photographs: DPKR2016; AT20080428_14, AT20080428_15

\section{Cucumis melo L.}

Common Names: Cantaloupe, rock melon

Kiribati Name: te meren ("melon")

Status: Recent introduction, although Cook's expedition reportedly planted "melons" on Cook Island in 1777-1778 (Maude, 1968). SW Asia, and possibly Africa, to the Mediterranean.

Abundance: Occasional.

Remarks: Food plant in houseyard gardens in London, Tabwakea and Banana in 1996 and 2006, and at the Agricultural Station in 2008.

Recorded: RRT 1996, 2006; AT 2008

Voucher Photographs: DPKR0363, 0754, 0770, 0802, 2018; AT20080428_28

Cucumis sativus L.

Common Name: Cucumber

Kiribati Name: te kukamba ("cucumber")

Status: Recent introduction. North India.

Abundance: Common. 
Remarks: Food plant, first observed about 1980, and now cultivated in houseyard gardens in London,

Tennessee, Tabwakea and Banana. In cultivation at the Agricultural Station in 2011.

Recorded: MCG 1979-1982; RRT 1996, 2006; AT 2011

Voucher Photographs: DPKR0301, 0302, 0748, 0749, 0783, 0801, 0822, 0825, 0826, 1154, 1156, 1159,

$1164 \mathrm{~b}, 2429$

Cucurbita moschata Duchesne ex Poir.

Synonyms: Cucurbita pepo L. (of some authors, but incorrectly for the species currently on Kiritimati)

Common Name: Pumpkin

Kiribati Name: te baukin, te banke (corruptions of the English "pumpkin")

Status: Recent introduction. Tropical America.

Abundance: Common.

Remarks: First observed in villages about 1980. Food plant in household gardens in settlements and at the Agricultural Station, and as an occasional adventive in waste places around villages and gardens. One of the few introduced food plants that does well in the atolls. Although earlier records might have been correctly referred to C. pepo, our records and photographs show that the species currently grown is C. moschata, with variegated green leaves with white flashes.

Recorded: MCG 1979-1982; LLW 1982; RRT 1996, 2006; AT 2008, 2009, 2011

Voucher Photographs: DPKR0207a, 0305, 0312, 0348, 0699, 1166, 1167, 1292; AT20080428_24

\section{Lagenaria siceraria L.}

Common Name: Bottle gourd

Kiribati Name: te bom ("bomb")

Status: Recent introduction. Tropical Asia.

Abundance: Uncommon.

Remarks: Planted in some houseyard gardens in London and Banana, 1996 and 2006.

Recorded: RRT 1996, 2006

\section{Momordica charantia L.}

Common Names: Bitter gourd, balsam pear

Status: Recent introduction. Paleotropics.

Abundance: Rare.

Remarks: Seen in one houseyard food garden in Banana in 1996; not found since.

Recorded: RRT 1996

\section{CUSCUTACEAe (CUSCUTA FAMILY)}

Cuscuta campestris Yuncker

Common Names: Golden dodder, field dodder

Status: Recent introduction. America; now widely introduced in Old World.

Abundance: Occasional.

Remarks: First recorded in 1965, west of "C site" (Artemia Corner), parasitic on Heliotropium anomalum. In the 1970s and early 1980s, common near Southeast Point, including around K site, and occasional between hypersaline ponds west of the main lagoon (MCG map). Found in 1996, and on one lagoon island in 1997. Parasitic vine, with tiny scale-like leaves and thin yellowish stems; much thinner and more delicate than the similar Cassytha filiformis.

Recorded: CRL 1965; RP 1977-1979; MCG 1979-1982; LLW 1982; RRT 1996; HLJ 1997 


\section{EUPHORBIACEAE (SPURGE FAMILY)}

Acalypha amentacea Roxb. ssp. wilkesiana (Müll. Arg.) Fosberg

Synonym: A. wilkesiana Müll. Arg.

Common Name: Painted copperleaf

Status: Recent introduction. SE Asia and Melanesia.

Abundance: Rare or extirpated.

Remarks: Reported only in the period 1979-1982. Probably introduced as an ornamental and perhaps not successful in the local climate.

Recorded: MCG 1979-1982

Chamaesyce hirta (L.) Millsp.

Synonyms: Euphorbia hirta L.; E. pilulifera L.

Common Names: Garden spurge, asthma plant, hairy spurge, old blood

Kiribati Name: te tarai

Status: Recent introduction. Pantropical.

Abundance: Abundant.

Remarks: First reported in 1924, but apparently already widespread "near the settlements and copra camps." Found at London and Paris in the 1930s. Locally common in the early 1980s, in waste areas and along roadsides in London, Main Camp, Cassidy Airport, Dakota Strip and Poland (MCG map). Since 1996, found as a weed in waste places, open areas, roadsides, and gardens throughout the island, including around Aeon Field, at the ruins of the old South Pacific Airways Hotel on the Paris peninsula, and near the old New Zealand Airfield at Te Kaba in the southwest. In March 2011, much less evident after a three-month dry period: a few plants surviving in London and at the airport; none at the South Pacific Airways Hotel.

Recorded: C\&B 1924; F\&M 1936; WAS 1965; RP 1977-1979; MCG 1979-1982; LLW 1982; RRT 1996, 2006; HLJ 1997; AT 2008, 2009, 2011, 2012

Voucher Photographs: DPKR0041, 0279, 1638, 2309a, 2396a; AT20080423_44

Chamaesyce hypericifolia (L.) Millsp. Synonyms: Chamaesyce glomerifera Millsp.; Euphorbia glomerifera (Millsp.) L.C. Wheeler Common Name: Graceful spurge

Kiribati Name: te tarai

Status: Recent introduction. Tropical America.

Abundance: Occasional.

Remarks: A single plant reported in 1982, in a waste area in village. In 1996, 2006 and 2008, occasional in ruderal sites and open areas in London, Tabwakea, Banana and at the airport. Garden, roadside and ruderal weed, commonly found among container plantings.

Recorded: LLW 1982; RRT 1996, 2006; AT 2008

Voucher Specimen: AT X025 London

Voucher Photographs: DPKR0044b, 0332, 0755, 2482b

Chamaesyce prostrata (Ait.) Small

Synonym: Euphorbia prostrata Ait.

Common Names: Prostrate spurge, red caustic creeper

Kiribati Names: te tarai, te amerika (an old name, probably because it is believed that American troops introduced it)

Status: Recent introduction. Tropical America.

Abundance: Occasional.

Remarks: Reportedly common in waste places and disturbed sites in 1982. An uncommon weed in dry ruderal sites and roadsides in London in 1996 and 2006; common in the open lot between the 
cathedral and the maneaba in London across from the sports field.

Recorded: MCG 1979-1982; LLW 1982; RRT 1996, 2006

Voucher Photographs: DPKR1998, 1999, 2000, 2001, 2002b

Chamaesyce thymifolia (L.) Millsp.

Common Name: Thyme-leafed spurge

Status: Recent introduction. India.

Abundance: Common.

Remarks: First recorded in 1982, near the docks in London. In 1996 an uncommon weed along roadside in main part of London, but by 2006 widespread in heavily trampled waste places in most settled areas throughout the island, including Poland. Also seen in sandy rocky area, inland from the south coast of the Southeast Peninsula near Four Brothers, in 2006. In many of the Gilbert Islands, seems to have largely replaced C. prostrata by the mid-2000s (RRT, pers. obs.), and similarly, now seems to be much more common than the latter in Kiritimati.

Recorded: RWH 1982; RRT 1996, 2006; AT 2009

Voucher Specimens: AT X003 Poland, X004 X005 wharf in London

Voucher Photographs: DPKR0143, 0145, 0249, 0275, 0276, 0277, 0288, 0289, 0290, 1497, 1626, 1924, 2002b, 2309b; AT20090918_02, AT20090918_04, AT20090922_20

Cnidoscolus chayamansa McVaugh

Common Names: Chaya, tree spinach

Kiribati Name: te tiaia ("chaya")

Status: Recent introduction. Mexico.

Abundance: Common.

Remarks: Not found in 1996 but in 2006-2011 a common combined hedge- and food-plant in gardens in all settlements and around many government buildings, sometimes growing to over $4 \mathrm{~m}$ high. Introduced in the early 1990s as part of the European Community Pacific Regional Agricultural Project (PRAP) for atolls. One of the few recent agricultural introductions that seems to be well suited to the atoll environment.

Recorded: RRT 2006; AT 2008, 2009, 2011

Voucher Photographs: DPKR0199, 0299, 0315c, 0806, 0837, 0849, 1265c, 1266b, 1276b, 1280b, 1291a; AT20080427_08, AT20080428_16, AT20090922_03

Codiaeum variegatum (L.) Bl.

Common Name: Croton

Status: Recent introduction. Malaysia to Melanesia.

Abundance: Rare.

Remarks: Planted ornamental. Single plant seen in London household garden in 1996 but not seen since.

Recorded: RRT 1996

Euphorbia cyathophora Murr.

Synonym: Eurphorbia heterophylla L. var. cyathophora (Murr.) Griseb.

Common Names: Mexican fire plant, wild poinsettia, dwarf poinsettia

Kiribati Name: te kabekau ("painted lady," "prostitute")

Status: Recent introduction. Tropical America.

Abundance: Common.

Remarks: Weed of roadsides and waste places. First reported in the late 1970s, when already common and widespread in disturbed areas. Seen in front of government buildings on the outskirts of London in 1996, and in all settlements and around the airport terminal in 2006-2011. Along the main road between London and Tabwakea in 2012. 
Recorded: RP 1977-1979; MCG 1979-1982; LLW 1982; RRT 1996, 2006; AT 2008, 2009, 2011, 2012

Voucher Photographs: DPKR0113, 0147, 1298, 1899, 1900, 2340; AT20080424_12, AT20080427_23

\section{Euphorbia pulcherrima}

Common Name: Poinsettia

Status: Recent introduction. Mexico.

Abundance: Rare.

Remarks: Seen in one houseyard garden in 1996, and a single plant over $2 \mathrm{~m}$ tall at the Captain Cook

Hotel in 2006. Not seen since; the plant at the hotel could not be found in 2008-2009.

Recorded: RRT 1996, 2006

Voucher Photographs: DPKR2478, 2479

\section{Euphorbia tirucalli L.}

Common Names: Pencil plant, naked lady, milk hedge

Status: Recent introduction. East Africa and India.

Abundance: Occasional.

Remarks: Seen in houseyard gardens, sometimes as part of hedges, in London in 1996 and in London, Tennessee, Tabwakea, Banana and Poland in 2006-2009.

Recorded: RRT 1996, 2006; AT 2008, 2009

Voucher Photographs: DPKR0201, 1210, 1224b; AT20080427_07

\section{Manihot esculenta Crantz}

Common Names: Cassava, manioc, tapioca

Kiribati Name: te tabioka ("tapioca")

Status: Recent introduction. Tropical America.

Abundance: Occasional.

Remarks: Food plant seen in London and Banana in 1996, and in houseyard gardens in all settlements in 2006 and 2008. Sometimes planted in containers or old tires. Roots cooked as a staple food.

Recorded: RRT 1996, 2006; AT 2008

Voucher Photographs: DPKR0219a, 0220a, 0222, 0799b, 0804, 1214

Pedilanthus tithymaloides (L.) Poit.

Common Names: Slipper flower, shoe spurge, red-bird

Kiribati Name: te raba ("rubber")

Status: Recent introduction. Caribbean.

Abundance: Occasional.

Remarks: Planted ornamental in houseyard gardens. Seen near Main Camp and in London in 1996, and in all settlements and some government offices in 2006-2011.

Recorded: RRT 1996, 2006; AT 2008, 2009, 2011, 2012

Voucher Photographs: DPKR0213, 0810, 0817, 0818, 1263, 1265a, 1283a; AT20080427_11

Phyllanthus amarus Sch. \& Th.

Synonym: Phyllanthus niruri L. (of Christophersen, 1927)

Common Names: Sleeping plant, six-o'clock

Kiribati Name: te kaimatu ("sleeping plant")

Status: Recent introduction. Africa.

Abundance: Common.

Remarks: In 1924 seen only near settlements. Since 1996 a weed of roadsides, houseyard and food gardens, open lots, waste places, pig-sties and other ruderal sites in all settlements and around government buildings, tourist accommodation and the airport, although much less common in early 2011 after a dry spell. Although mostly associated with settlements, occasionally dominant 
elsewhere in places, such as open grassy areas north of Poland. Commonly eaten by chickens.

Recorded: C\&B 1924; F\&M 1936; LWB 1945; MCG 1979-1982; RRT 1996, 2006; AT 2008, 2009, 2011, 2012

Voucher Specimen: AT X037 London

Voucher Photographs: DPKR0049, 0118, 1282, 1915, 2412b; AT20080423_45, AT20080430_06, AT20080430_07

\section{FABACEAE (PEA FAMily)}

Bauhinia malabarica Roxb.

Common Name: Malabar bauhinia

Status: Recent introduction. Burma.

Abundance: Rare.

Remarks: A single mature ornamental plant growing as a shrub approximately $2 \mathrm{~m}$ tall in Banana village in 1996, still there and $4 \mathrm{~m}$ tall in 2006 and 2009. Flowers with three fertile stamens.

Recorded: RRT 1996, 2006; AT 2009

Voucher Photographs: DPKR1253, 1254; AT20090922_31, AT20090922_33

Delonix regia (Boger ex Hook.) Raf.

Common Names: Flame tree, flamboyant

Kiribati Name: te tua ("the government")

Status: Recent introduction. Madagascar.

Abundance: Rare.

Remarks: Two small trees, the tallest approximately $2 \mathrm{~m}$ tall, at the Agricultural Station in 2009, where they had been planted as ornamentals.

Recorded: AT 2009

Voucher Photograph: AT20090922_35

Erythrina variegata var. orientalis (L.) Merr.

Synonym: E. indica Lam. (of Christophersen 1927)

Common Names: Coral tree, dadap

Status: Recent introduction. Indo-Pacific.

Abundance: Probably extirpated.

Remarks: Observed as an ornamental, identified as E. indica but not collected, in 1924; an Erythrina sp. observed between 1935 and 1938 "growing around settlements"; and E. v. orientalis was observed in 1982. Never collected, and not reported recently: the 1982 specific identification was based on E. v. orientalis being the commonly planted tree in east Polynesia.

Recorded: C\&B 1924, EHB 1935-1938; LLW 1982; additional details for this record provided by L. L. Wester (pers. comm.)

Leucaena leucocephala (Lam.) de Wit

Synonym: Leucaena glauca sensu Hawn. non (L.) Benth.

Common Names: Leucaena, tangan tangan

Kiribati Name: te kai te tua ("the government tree")

Status: Recent introduction. Tropical America.

Abundance: Occasional.

Remarks: First recorded in 1936, when already adventive, but noted as uncommon by most recorders since then. Seen near pig pens in London in 1996 and behind the JAXA Station in 2006. In 20082011 it was found in a few houseyard gardens, and in waste places near government buildings and along the lagoon shore in London, where producing abundant seed, apparently increasing and spreading slowly out from the original focus. Found in Banana in 2009. A small grove mixed 
with Hibiscus tiliaceus, around the ruins of Rougier's house at the tip of the Paris peninsula in 2011, did not appear to be spreading into the surrounding area despite fruiting prolifically.

Wherever found, most plants seem not particularly vigorous, only growing up to c. $2 \mathrm{~m}$ tall (3-4

$\mathrm{m}$ at the Paris site). Known as a serious invader on many other Pacific islands but perhaps less vigorous on atolls (e.g., Catala 1957).

Recorded: Fosberg 1936, specimen 12171[AT!] at BISH; F\&M 1936; FLH 1957; MCG 1979-1982; RRT 1996, 2006; AT 2008, 2009, 2011

Voucher Photographs: DPKR0163, 0164, 0679, 1622; AT20080428_04, AT20090918_01, AT20090918 02

Macroptilium atropurpureum (DC.) Urb.

Common Name: Siratro

Status: Recent introduction. Tropical and subtropical America.

Abundance: Uncommon.

Remarks: First recorded around 1980. Now a weed in waste places in London. In 2006, noted in two locations near the Tekabaia Guest House and in an open lot near government buildings in the main port area. In 2008-2009, still found in these areas, but also as a carpet over the ground and other vegetation, more or less continuously from the wharf area northwards along the port peninsula, along the landward side of the road. Less common but still visible on the port peninsula in 2011 after a dry period.

Recorded: MCG 1979-1982; RRT 2006; AT 2008, 2009, 2011

Voucher Specimen: AT X015 London

Voucher Photographs: DPKR0126, 0127, 0128, 2397; AT20080427_25, AT20080427_26, AT20080427 27

Macroptilium lathyroides (L.) Urb.

Synonym: Phaseolus lathyroides L.

Common Names: Wild bean, cow pea

Status: Recent introduction. Tropical America.

Abundance: Extirpated. One record, a weed around the settlement at Paris in 1936. Not seen since.

Recorded: F\&M 1936; Fosberg 1936, specimen 13272[AT!] at BISH

Phaseolus vulgaris L.

Common Names: String bean, French bean, haricot bean

Status: Recent introduction. Tropical America.

Abundance: Rare.

Remarks: Recorded only once, a seedling in a food plant garden near the Health Centre in London, 1996.

Recorded: RRT 1996

Voucher Photograph: DPKR0786

Senna occidentalis (L.) Link

Common Names: Coffee senna, arsenic bean

Kiribati Name: te bin

Status: Recent introduction. Tropical America.

Abundance: Occasional.

Remarks: First recorded in 1996, now a weed of open lots, waste places and roadsides in London,

Tabwakea and Banana, sometimes in dense patches. More conspicuous during the dry season when in flower and fruit, but disappears during more prolonged dry spells: scarcely any seen in March 2011 after a three-month dry period.

Recorded: RRT 1996, 2006; AT 2009, 2011 
Voucher Specimen: AT X020 London

Voucher Photographs: DPKR0153, 0154, 0214, 0282b; AT20090923_01, AT20090923_03

\section{Sophora tomentosa L.}

Common Name: Silverbush

Kiribati Name: te nikamatutu, te kaimatu

Status: Indigenous to the region but recent introduction to Kiritimati. Indian Ocean to Micronesia and east Polynesia.

Abundance: Rare.

Remarks: Three planted in the Agricultural Station, about $2 \mathrm{~m}$ high in 2006, 3-4 $\mathrm{m}$ in 2008-2009; in 2011-2012 pruned back to $<2 \mathrm{~m}$ and a few new seedlings planted, but not yet distributed by Agriculture to the island communities (T. Teraira, pers. comm.). Said by local people to have been introduced throughout Kiribati from Onotoa Atoll as a nitrogen-fixing tree (RRT, pers. obs.).

Recorded: RRT 2006; AT 2008, 2009, 2011, 2012

Voucher Photographs: DPKR1178, 1179, 1191; AT20080426_08, AT20080426_09

Vigna marina (J. Burm.) Merr.

Common Name: Yellow beach pea

Kiribati Names: te kitoko, te ruku

Status: Indigenous to the region but probably a recent deliberate introduction to Kiritimati. Pantropical. Abundance: Rare.

Remarks: Found in one houseyard garden in 1996, along the main coastal road to the Port Settlement in London and in one houseyard garden in Banana in 2006, and by the main road in Banana in 2009. Planted on South Tarawa (Gilbert Islands) as a nitrogen-fixing plant.

Recorded: RRT 1996, 2006; AT 2009

Voucher Photographs: DPKR0257, 0258, 0261, 0262, 0263b; AT20090922_30

\section{GOODENIACEAE (NAUPAKA FAMILY)}

Scaevola taccada (Gaertn.) Roxb.

Synonyms: Scaevola sericea Vahl.; S. frutescens (Mill.) Krause (of Christophersen, 1927 and others); S. plumieri (L.) Vahl (of Streets 1877)

Common Names: Beach saltbush, half-flower

Kiribati Name: te mao

Status: Indigenous. Tropical Asia to Hawaii.

Abundance: Very abundant throughout the island (MCG map).

Remarks: An important component of the strand vegetation on both ocean and lagoon coasts; forms almost monospecific thickets on the open ocean coasts of the main island, and in some inland areas especially on flats with smaller lagoons in the north, where Suriana maritima and Tournefortia often predominate. Also found in extensive thickets and as patches on rocky and gravelly areas, in poorly maintained coconut plantations, and in waste places. Sometimes planted along roads and causeways and in household gardens. Also common in coastal vegetation and in interior herblands and scrubland on the islets of Motu Upua, Motu Tabu, Cook Island and Ngaon te Taake. Extensive areas of dead plants seen in low-lying, hypersaline areas in Algeria in 2006. Coastal clumps may protect coastlines from wave erosion. Commonest host of Cassytha filiformis. Flowers used in garlands; fruits used in traditional magic; juice of fruit applied directly to sore eyes and burns and used as a drink to induce abortion; branches sometimes used for roofing strips; stem tips used with water as an astringent.

Recorded: THS 1874; C\&B 1924; SFC 1934; F\&M 1936; LWB 1945; MDG 1958-1959; DCH 1962; RNJ 1965; RP 1977-1979; MCG 1979-1982; RWH 1982; LLW 1982; RRT 1996, 2006; HLJ 
1997; AT 2008, 2009, 2011, 2012

Voucher Photographs: DPKR0009b, 0043, 0452, 0460a, 0469, 0594b, 0595a, 0921, 0933, 0936, 0946a, 0981a, 0985, 1170, 1331, 1334, 1335, 1345, 1360, 1362a, 1364, 1365, 1368a, 1410a, 1413c, $1417 \mathrm{c}, 1465,1467,1477 \mathrm{a}, 1478,1530 \mathrm{~b}, 1540,1561,1573,1591,1592,1662 \mathrm{a}, 1680,1749 \mathrm{a}$, 1786a, 1799a, 1841, 1849b, 1954a, 2027a, 2029a, 2032b, 2248a, 2249, 2267, 2288b, 2293a, 2328a, 2370; AT20080423_19, AT20080428_32, AT20080428_34, AT20090920_00

\section{LAMIACEAE (MINT FAMILY)}

\section{Ocimum tenuiflorum L.}

Common Names: Basil, holy basil, tulasi

Kiribati Name: te marou

Status: Recent introduction. Africa to Pacific islands.

Abundance: Common.

Remarks: Not recorded before 1996, but now planted in house gardens in London, Tabwakea, Tennessee, Banana and Poland and in gardens at hotels and government building. Adventive in disturbed sites near houses, along roadsides and in waste places in villages. Has smaller, tougher and often darker purplish leaves as compared with sweet basil O. basilicum. Leaves and flowers used in garlands, rather than as a pot-herb.

Recorded: RRT 1996, 2006; AT 2008, 2009

Voucher Specimen: AT X041 Poland

Voucher Photographs: DPKR0253, 0271, 0303, 0761, 1654, 2319; AT20080426_71, AT20090922_06

\section{LAURACEAE (LAUREL FAMILY)}

\section{Cassytha filiformis L.}

Common Names: Laurel dodder, beach dodder, devil's twine

Kiribati Name: te ntanini

Status: Indigenous. Pantropical.

Abundance: Abundant.

Remarks: Parasite on other plants, generally on natural vegetation, especially Scaevola taccada, but regarded as an agricultural pest, particularly of coconut seedlings; found in inner coastal strand vegetation, in grasslands, herblands, shrublands and woodlands, and in ruderal sites throughout (MCG map). Often almost totally covers or festoons individual shrubs or trees. Locally common on Motu Upua, Motu Tabu, Cook Island and Ngaon te Taake islets, growing on shrubs, trees and in the central herblands. Slightly acidic fruit sometimes eaten by children; dried stems sometimes used in dancing skirts (riri) and in, or as, garlands; crushed stem used to treat jellyfish stings.

Recorded: FDB 1835; C\&B 1924; F\&M 1936; LWB 1945; MDG 1958-1959; DCH 1962; RNJ 1965; RP 1977-1979; MCG 1979-1982; LLW 1982; RRT 1996, 2006; HLJ 1997; AT 2008, 2009, 2011, 2012

Voucher Photographs: DPKR0342, 0343, 0412, 0454a, 0596a, 0689, 0945, 1146b, 1380d, 1410b, 1464c, 1504b, 1505b, 1506b, 1854b, 2093a, 2226, 2266b; AT20120318_32

\section{MALVACEAE (MALlow FAMiLy)}

Abelmoschus esculentus (L.) Moench

Common Name: Okra

Status: Recent introduction. Northeast Africa.

Abundance: Rare.

Remarks: Seen in a home food garden at Banana village in 1996.

Recorded: RRT 1996 
Abelmoschus manihot (L.) Moench

Synonym: Hibiscus manihot L.

Common Names: Hibiscus spinach, edible hibiscus, pele

Kiribati Names: nambere, te bere

Status: Recent introduction. Tropical Asia.

Abundance: Occasional.

Remarks: Planted in food gardens in London and Banana in 1996 and in all settlements in 2006-2009.

According to local informants, introduced as a food plant from Fiji, Banaba (Ocean Island) and

Nauru at different times since the 1980s and promoted as a nutritious leafy green vegetable to

address vitamin A and iron deficiency. Was more common in 1996, before the introduction of

Cnidoscolus chayamansa, which serves a similar purpose and is now more commonly cultivated.

Present at the Agricultural Station in 2009.

Recorded: RRT 1996, 2006; AT 2008, 2009

Voucher Photographs: DPKR0208, 0278, 0798, 0814, 0815, 1302, 1303; AT20090922_38

Abutilon indicum (L.) Sweet ssp. albescens (Miq.) Borssum-Waalkes

Synonyms: Abutilon albescens Miq.; A. asiaticum (L.) Sweet var. albescens (Miq.) Fosb.

Kiribati Name: te kaura ni Banaba

Status: Indigenous to the region but perhaps a recent introduction to Kiritimati. SE Asia to the Pacific islands.

Abundance: Rare.

Remarks: Reported to be locally common among Tournefortia argentea near Four Brothers in the southeast in 1936, but then not reported again until about 1980, when a yellow-flowered Abutilon was found growing under Tournefortia argentea bushes on the south side of the southeast peninsula, inland from the track (MCG, pers. comm.). Not found since in the wild, but may have been overlooked among the abundant Sida fallax. In 2006, seen planted in one flower garden at Captain Cook Hotel, possibly from a new introduction. Not found in 2008-2012.

Recorded: F\&M 1936; Fosberg 1936, specimen 13215[AT!] at BISH; MCG 1979-1982; RRT 2006 Voucher Photographs: DPKR0010, 0011, 0012, 2468, 2469, 2470, 2471

Hibiscus rosa-sinensis $\mathrm{L}$.

Common Names: Hibiscus, red hibiscus, China rose

Kiribati Name: te roti ("rose")

Status: Recent introduction. Tropical Asia.

Abundance: Common.

Remarks: Two plants reported (as two different varieties of Hibiscus sp. with pink flowers) in 1962; now several varieties planted as ornamentals in houseyard gardens in all settlements. Flowers used for decoration and worn in the hair or over the ear.

Recorded: DCH 1962; MCG 1979-1982; LLW 1982; RRT 1996, 2006; AT 2008, 2009, 2011, 2012

Voucher Photographs: DPKR0781, 0782, 0794, 0795b, 0838, 1250b, 2382; AT20080426_02

\section{Hibiscus tiliaceus L.}

Common Names: Beach hibiscus, beach mallow

Kiribati Name: te kiaiai (S. Gilbert Islands), te raui (N. Gilbert Islands)

Status: Indigenous to the region but probably introduced to Kiritimati. Pantropical.

Abundance: Common.

Remarks: In 1924 the 1930s, 1965 and 1982, reportedly only present at settlements or persisting from former cultivation, including at Paris. Today, still planted in household gardens and public places and as a street tree in London, Tabwakea, the Captain Cook Hotel and Banana. Still present at Paris in 2011, in a small grove mixed with Leucaena leucocephala, around the ruins of Rougier's house. Occasional in open lots in and around villages and apparently adventive in places in 1982, 
2006 and 2008. The retted bast fibre is used to make dancing skirts (riri); branches sometimes used as outrigger booms and straight young stems or branches as fishing poles; flowers used in garlands; leaves used to wrap food and cover earth ovens and at least formerly as mulch in taro pits.

Recorded: C\&B 1924; F\&M 1936; DCH 1962; RNJ 1965; MCG 1979-1982; LLW 1982; RRT 1996, 2006; AT 2008, 2009, 2011, 2012

Voucher Photographs: DPKR0140, 0141, 0174, 0175b, 0177b, 0248, 0361, 1257a, 1309b, 1978; AT20080428_03

Sida fallax Walp.

Synonyms: S. dielii Gray; includes S. rotundifolia and S. cordifolia L. (of Bennett, 1840 and Christophersen, 1927, respectively)

Common Name: Golden mallow

Kiribati Name: te kaura ("yellow")

Status: Indigenous. Indo-Pacific.

Abundance: Abundant throughout the island (MCG map).

Remarks: Small shrub in most open, dry sites. Also common in houseyard gardens, in open lots, waste places and ruderal sites in all villages. Occasional on Motu Upua, Motu Tabu and Ngaon te Taake islets in drier, rockier areas of herbland. Common on the drier rocky isthmus on Cook Island. Bright yellow-orange flowers used in garlands and head bands; there are many legends and stories about te kaura partly because it is the flower of the chiefly atoll of Abemama.

Recorded: FDB 1835; THS 1874; C\&B 1924; F\&M 1936; LWB 1945; FLH 1957; MDG 1958-1959; DCH 1962; RNJ 1965; RP 1977-1979; MCG 1979-1982; RWH 1982; LLW 1982; RRT 1996, 2006; HLJ 1997; AT 2008, 2009, 2011, 2012

Voucher Photographs: DPKR0158, 0259, 0341, 0497, 0511a, 0705, 0894, 0970c, 1243, 1244, 1428a, 1429a, 1431, 1432a, 1433b, 1597b, 1620, 1739b, 1881b, 1938, 2046, 2193a, 2265, 2342, 2343b, 2408; AT20080423 29

Sida rhombifolia L.

Common Names: Broomweed, broom plant, Cuba jute

Kiribati Name: te kaura ("yellow"), te kaura ni i-matang

Status: Recent introduction. Pantropical.

Abundance: Rare or extirpated.

Remarks: Only reported in August 1924, in sand near settlements.

Recorded: Bergman 1924, specimen 18[AT!] at BISH; C\&B 1924

\section{MORACEAE (MULBERRY FAMILY)}

Artocarpus altilis (Park.) Fosb.

Synonyms: Artocarpus incisus (Thunb.) L.f.; Artocarpus communis Forst.

Common Name: Breadfruit

Kiribati Names: te mai (general term for Artocarpus taxa), bukiraro (for seedless varieties)

Status: Recent introduction. Malayo-Pacific.

Abundance: Common.

Remarks: First reported ("4 small cultivated trees in the Resident Commissioner's residence") in 1962, and "in cultivation" in 1982. Now planted as a staple food tree in household gardens in London, Tabwakea, Banana and Poland.

Recorded: DCH 1962; MCG 1979-1982; LLW 1982; RRT 1996, 2006; AT 2008, 2011

Voucher Photographs: DPKR0708, 0729, 0730, 1232, 1233, 1237, 1241a, 1315, 1920, 2346, 2347, 2430 
Artocarpus altilis $\mathrm{x}$ mariannensis

Common Name: Seeded hybrid breadfruit

Kiribati name: te mai keang

Status: Recent introduction. Pacific islands aboriginal hybrid cultivar (seeded), usually with deeply divided leaves.

Abundance: Common.

Remarks: Not reported before 2006, but many large trees were present in 2008, so probably introduced at least 10 years previously. Staple food tree planted in gardens in the villages from London to Banana. The name te mai keang is because the leaves are considered to resemble the leaves of the fern, te keang (Microsurum grossum Langsd \& Fisch.), which is found on many of the atolls of the Gilbert Islands.

Recorded: RRT 2006; AT 2008, 2009, 2011

Voucher Photographs: DPKR0709, 0719, 0734, 0735, 0736, 0737, 0738; AT20090919_00

Artocarpus mariannensis Trec.

Common Names: Marianas breadfruit, dugdug

Kiribati Name: te mai tarika, te mai kora

Status: Recent introduction. Micronesia.

Abundance: Occasional.

Remarks: First reported in 1996 and possibly introduced about the same time as A. altilis. Planted staple fruit tree (seeded) in household gardens, especially in Tabwakea.

Recorded: RRT 1996, 2006; AT 2009, 2011

Voucher Photographs: DPKR0696, 0697, 0706, 0724, 0726, 0733, 0819

\section{Ficus carica L.}

Common Name: Common fig

Kiribati Name: te biku

Status: Recent introduction. Mediterranean.

Abundance: Rare.

Remarks: Small tree (approximately $3 \mathrm{~m}$ tall) bearing fruit, at the Agricultural Station, and cuttings in cultivation there, in 2009. In 2011, some of these cuttings were fruiting.

Recorded: AT 2009, 2011

Voucher Photographs: AT20090922_39, AT20090922_40, AT20090922_43

Ficus tinctoria Forst. f.

Common Names: Dyer's fig, Pacific fig

Kiribati Name: te bero

Status: Recent introduction. SE Asia to Micronesia and Polynesia.

Abundance: Occasional.

Remarks: Present in the 1970s and in cultivation around settlements in 1982. Now planted as a food tree and ornamental in houseyard and public gardens in London, Tabwakea and Banana. An important supplementary staple food crop; the ripe figs are cooked and crushed to make a flour, which can be made into a pudding after sweetening with toddy syrup (kamaimai) or sugar, or made into a preserved breadlike substance, kabuibui ni bero, which, after complete drying, can be stored in tins for several months; fruits also used in the past in the Gilberts for dying objects such as hats, mats, etc.; leaves fed to pigs and sometimes used in composts; branches used in building houses, especially as supports for roof thatching.

Recorded: RP 1977-1979; MCG 1979-1982; LLW 1982; RRT 1996, 2006; AT 2008, 2009

Voucher Photographs: DPKR0225, 0700, 0701, 0709, 0746, 1896, 1901; AT20080428_29, AT20080428 30 


\section{MORINGACEAE (MORINGA FAMILY)}

Moringa oleifera Lam.

Common Name: Horseradish tree, drumstick tree, saijan

Kiribati Name: te kai turam ("drum tree")

Status: Recent introduction. India.

Abundance: Occasional.

Remarks: Food plant in houseyard gardens in London, Tabwakea, Banana and Poland, and at the

Agricultural Station. Recently introduced into Kiribati (since the early 1980s) by Filipino

families, and food and agricultural programmes. Used as a leaf vegetable.

Recorded: RRT 1996, 2006; AT 2008, 2009, 2011

Voucher Photographs: DPKR0788, 0789, 1189, 1273, 1922, 2338b; AT20080427_13, AT20080427_14, AT20110309 05

\section{NYCTAGINACEAE (FOUR-O'CLOCK FAMILY)}

Almost all writers on the flora of Kiritimati have remarked that the systematics of the genus Boerhavia need attention (e.g. Christophersen, 1927; Fosberg, 1978, 1988; Wester, 1985). C.R. Long made a large collection of Pacific Boerhavia, most of which is at BISH, as are many Boerhavia specimens collected by others, such as Fosberg and Wester, from Kiritimati and other Line and Phoenix islands. Most of CRL's and many of these other Boerhavia are sp. indet., including plants with white, pink or purple flowers, perennial or annual, a range of pubescence, and stems up to $8 \mathrm{~m}$ long. CRL collected many more Boerhavia than any other plant and was obviously interested in sorting them out, or helping someone else to do so. That job remains to be completed for Pacific Boerhavia (including molecular investigation), although some progress has been made (N.A. Douglas, pers. comm.).

We are unable to assign most of our own records with confidence to any particular taxon, and have dealt with them and previous records below by referring them to the taxa accepted by Fosberg (1978). Fosberg (1978) considered two major groups of species in the Indo-Pacific region, the B. diffusa group with strictly terminal, paniculate inflorescences, and the B. repens group (which includes B. tetrandra) with axillary, cymous or umbellate inflorescences. Following Fosberg (1978), in the BISH collection (when consulted by AT in 2010) B. diffusa was recognised as clearly separate from B. tetrandra and B. repens, but many BISH specimens of the plant that is widespread on Kiritimati, that is, what we here and others have called B. tetrandra, were classified under B. diffusa. Formerly, tetrandra (but not repens) was regarded as a subspecies of diffusa, so each Kiritimati record of "diffusa" needs assigning carefully to one of these two (or three) species. The native distribution of B. repens sensu stricto is only from Africa to Malesia, so Pacific specimens of the repens group should be B. tetrandra (Fosberg, 1978), unless they represent recently introduced populations.

Some Pacific white-flowered plants have been assigned to B. albiflora (described from the Phoenix Islands by Fosberg 1978 and placed in the B. repens group), but we are not confident that white-flowered plants on Kiritimati have been correctly distinguished from white-flowered $B$. tetrandra (or another species), as apparently treated by Christophersen (1927) and other authors on the Kiritimati flora. Apart from flower color, the major characters distinguishing albiflora from tetrandra were number of stamens, pubescence on the perianth and a tendency in albiflora for the leaves to reduce in size distally along the stem (Fosberg, 1978). We have found plants with white, pink or purple flowers, including both white and pink on the same individual, white-flowered and pink-flowered plants whose leaves reduce along the stem and others whose leaves do not reduce, and white-flowered plants with up to 4 stamens. We have not found plants with only terminal inflorescences or strictly red (rather than pinkish) flowers, which are the key characters of B. diffusa (Fosberg, 1978; N.A. Douglas, pers. comm.), so this taxon may not exist on the island. We have therefore placed almost all records within B. albiflora and B. tetrandra below, while leaving open the possibility of the presence of $B$. repens as a recent introduction, and recognizing that this 
treatment will remain unsatisfactory until a revision including molecular analysis of the genus within the Pacific has been carried out.

Boerhavia albiflora Fosb.

Common Name: White-flowered boerhavia

Kiribati Name: te wao

Status: Indigenous. Offshore islands of Australia to the central Pacific islands.

Abundance: Occasional?

Remarks: White-flowered plants found in herblands, including on offshore islands such as Motu Upua, often in the same areas as B. tetrandra.

Recorded: RRT 2006, AT 2008, 2011

Voucher Photographs: DPKR0415, 1621, 1637

\section{Boerhavia repens L.}

Status: Possible recent introduction. Africa to Malesia.

Abundance: Uncommon?

Remarks: Plants resembling this species were encountered as a weed of roadsides, waste places and ruderal sites in and around villages, although no voucher specimens could be unequivocally assigned to it.

Voucher Photographs: DPKR0704, 1463

\section{Boerhavia tetrandra Forst.}

Synonyms: Boerhavia diffusa sensu auct. non L.; B. hirsuta L. (of Bennett, 1840; Christophersen, 1927); B. repens L. (of Garnett, 1983, and others)

Common Names: Boerhavia, pigweed

Kiribati Names: te wao, te wao $n$ anti

Status: Indigenous. Polynesia and Micronesia.

Abundance: Abundant.

Remarks: In open rocky and sandy sites, both inland and near the ocean coast. One of the most common components of open herblands and grasslands throughout the island. Especially common on Motu Upua and Motu Tabu, in sandier sites that are the preferred seabird nesting areas. An important component of central herblands and scrublands on Cook Island and Ngaon te Taake islet. Forms almost continuous single-species stands in places. Very variable, with flowers ranging from white to purple, stems from green to red, and plant glabrous to pubescent. As B. "repens," reported to be widespread in Lepturus grassland by MCG 1979-1982 (map) and HLJ 1997; other early records of diffusa and repens were probably (at least mostly) this species. Plant fed to pigs; used as a vegetable in time of food scarcity, but can reportedly affect the kidneys; leaf petioles crushed and boiled in toddy to treat te ba (rickets?); at least formerly, leaves used in compost for babai.

Recorded: FDB 1835; THS 1874; C\&B 1924; GPW 1924; SFC 1934; F\&M 1936; LWB 1945; WFC 1957; JPG 1958; MDG 1958-1959; DCH 1962; CRL 1964; WAS 1965; RNJ 1965; RWH 1982; LLW 1982; RRT 1996, 2006; AT 2008, 2011, 2012

Voucher Specimen: AT X022 London

Voucher Photographs: DPKR0019, 0020, 0021, 0023c, 0029b, 0083, 0416, 0462, 0557a, 0868a, 1045b, 1090, 1127a, 1173a, 1446b, 1458a, 1505a, 1569, 1785, 2419; AT20080426_01, AT20080426_02, AT20120319_33, AT20120319_34

Bougainvillea x buttiana Holttum \& Standley

Common Name: Hybrid bougainvillea

Kiribati Name: te akanta

Status: Recent introduction. Horticultural hybrid.

Abundance: Occasional. 
Remarks: Sometimes mistakenly identified as Bougainvillea spectabilis Willd. Planted since at least the 1980s as an ornamental in houseyard gardens in all main settlements and around government buildings, hotels, guest houses and other buildings. Flowers used in garlands.

Recorded: MCG 1979-1982; LLW 1982; RRT 1996, 2006; AT 2008, 2009, 2011, 2012

Voucher Photographs: DPKR0364, 0365 0678, 0845, 1916a, 2420b, 2422, 2449; AT20080427_05

Mirabilis jalapa L.

Common Names: Four-o'clock, marvel of Peru, false jalap

Kiribati Name: te auaua, te awa aua ("four o'clock")

Status: Recent introduction. Mexico.

Abundance: Rare.

Remarks: First recorded in 1964. Planted ornamental in one houseyard garden in London and one at Tabwakea in 2006. One plant at the Captain Cook Hotel in 2008 had disappeared 18 months later. Reportedly used to treat rickets by boiling a handful of petioles in toddy, which is then drunk to correct distortion of the bones; flowers used in garlands.

Recorded: CRL 1964; RRT 1996, 2006; AT 2008

Voucher Photographs: DPKR0720, 0721, 0722, 0739, 0740, 0745, 0762, 2475; AT20080427_37

Pisonia grandis $\mathrm{R}$. Br.

Common Names: Buka, puka, great lettuce tree, great birdcatcher tree

Kiribati Name: te buka

Status: Indigenous to the region and perhaps native to Kiritimati, but conceivably an aboriginal introduction. Indo-Pacific.

Abundance: Occasional.

Remarks: Origin and status unclear: first reported in 1924, when only three trees were found "in the northern part of the island"; in 1959 and 1965 a few trees reported on Motu Tabu and at SE Corner (still present at both sites: see below). However, the paucity of early reports might not be representative of its true status, and its distribution as reported subsequently (late 20th century) suggests it may be native. Thus, it is not clear whether it has declined or increased; it could conceivably have been an important component of inland and coastal forest in the past and have been replaced during the expansion of coconut plantations, while on the other hand it has been planted deliberately in places more recently. Forms a large grove in the center of Motu Tabu and a small stand just inland from the east-central coast of Motu Upua. One large stand $1 \mathrm{~km}$ southeast of Dakota Strip, near Southeast Point, where first reported in 1959. A third stand was reported near northwest point about 1980 (MCG map). Now also found in inner lagoon forest north of London; also planted in many houseyard gardens, often as a living fence or hedge, in Tabwakea, London and Banana. An important seabird rookery species on lagoon islets, where it often constitutes the dominant tree species. Soft wood sometimes used to make outrigger and fishnet floats; unspecified medicinal use reported. Young leaves edible and fed to pigs; cultivation of Pisonia as a green vegetable has been promoted in Kiribati since the 1980s to address vitamin deficiency, especially vitamin A deficiency in the modern diet.

Recorded: C\&B 1924; SFC 1934; MDG 1958-1959; RNJ 1965; MCG 1979-1982; LLW 1982; RRT 1996, 2006; AT 2008, 2009, 2011, 2012

Voucher Photographs: DPKR0353, 0354, 0494, 0495, 0496, 0527, 0529, 0537b, 0556d, 0655, 0668, 0669, 0673, 0675, 0676, 1258, 1289, 1291, 1425b, 1437, 1438, 1439, 1442f, 1524d, 1911a; AT20110306_40

\section{PASSIFLORACEAE (PASSION FLOWER FAMILY)}

\section{Passiflora foetida L.}

Common Names: Stinking passion flower, love-in-a-mist 
Kiribati Name: te biku, te bin

Status: Recent introduction. Tropical America. Rare. Seen growing on a fence in London in 1996 and at the same site in 2006 and in 2008; still there in 2009 (R. Bebe, pers. comm.). Tangy fruit eaten by children, birds and rats.

Recorded: RRT 1996, 2006; AT 2008

Voucher Photographs: DPKR0682, 0683, 2390, 2391, 2392, 2393

\section{Polygonaceae (BuCKWheat Family)}

Coccoloba uvifera (L.) L.

Common Name: Sea grape

Status: Recent introduction. Caribbean.

Abundance: Rare.

Remarks: One old, spreading tree found in a garden in London in 2009, approximately $5 \mathrm{~m}$ tall and carrying developing fruit.

Recorded: AT 2009

Voucher Photograph: AT20090918_02

\section{Portulacaceae (Purslane Family)}

Portulaca lutea Solander ex Forst. f.

Synonyms: P. fosbergii v. Poelln.; P. johnii v. Poelln.

Common Name: Seaside purslane

Kiribati Name: te boi

Status: Indigenous. New Caledonia to Pitcairn Island, Hawaii and Kiribati.

Abundance: Abundant.

Remarks: Dry open sites, scrublands and herblands throughout the island (MCG map), often with Sida fallax, Boerhavia tetrandra, Helioptropium anomalum and Lepturus repens; the main component in some drier herblands, often extending to the coastal zone. Also on the islets of Motu Upua, Motu Tabu, Cook Island and Ngaon te Taake. Plant fed to pigs and seeds eaten by chickens; leaves eaten by people in times of food scarcity.

Recorded: FDB 1835; C\&B 1924; GPW 1924; SFC 1934; F\&M 1936; MDG 1958-1959; DCH 1962; CRL 1964; RNJ 1965; MCG 1979-1982; LLW 1982; RRT 1996, 2006; HLJ 1997; AT 2008, 2009, 2011, 2012

Voucher Photographs: DPKR0026, 0078, 0420a, 0498, 0591b, 0592a, 0906, 0907a, 0956a, 0982, 1084a, 1091a, 1120a, 1342, 1405a, 1588a, 1826a, 2227, 2236a, 2250a, 2255; AT20080423_37, AT20080423_39

\section{Portulaca oleracea L.}

Common Names: Pigweed, purslane

Kiribati Name: te boi

Status: Recent introduction. Europe, now a cosmopolitan introduction.

Abundance: Seasonally common, at least since the 1960s, virtually disappearing after dry periods.

Remarks: Weed of roadsides, vegetable gardens, pig pen areas and waste places, especially on sandy soils and in the wet season; becomes much less evident during the dry season. Also seen at disturbed site at copra cutters' camp near Algeria. Leaves eaten in times of food scarcity and fed to pigs.

Recorded: F\&M 1936; MDG 1958-1959; DCH 1962; CRL 1964; RNJ 1965; MCG 1979-1982; LLW 1982; RRT 1996, 2006; AT 2008, 2009, 2011

Voucher Photographs: DPKR0013, 0046, 0149, 1180, 1817a, 2327a; AT20080426_24 


\section{RUBIACEAE (COFFEE FAMILY)}

\section{Gardenia taitensis DC.}

Common Names: Tahitian gardenia, tiare Tahiti

Kiribati Name: te tiare

Status: Recent introduction. Pacific Is.

Abundance: Occsional in London, uncommon elsewhere.

Remarks: One mature plant seen near store at Main Camp in 1996. Three very large flowering bushes seen in the same location and other mature large shrubs in flower at another location in Main Camp near the hotel, and in Tabwakea village in 2006. Frequent in gardens in London and Tabwakea in 2008-2009.

Recorded: RRT 1996, 2006; AT 2008, 2009

Voucher Photographs: DPKR0123, 1312, 1313, 1314, 1325, 2420a

\section{Guettarda speciosa L.}

Common Name: Guettarda

Kiribati Name: te uri

Status: Indigenous to the region but reported, by local informants, that the current trees were introduced to Kiritimati from other wetter Line Islands. Tropical Asia to the Pacific islands.

Abundance: Occasional.

Remarks: Not certainly reported before 1964, but now frequently planted as a multipurpose tree in household gardens in London, Tabwakea, Banana and Poland and around government buildings and tourist accommodation, including the Captain Cook Hotel. Seen apparently naturalized in one instance, in oceanside coastal strand forest on northwest coast in 1996. Its leaf-fall is considered to make the most fertile soil (te ianaur or te iarauri), which is scraped from under Guettarda trees and added to composts for babai and other cultivated plants; wood used for rafters, wall frames and canoe hulls and ribs; formerly used in firemaking by friction; the fragrant, night-blooming flowers are popular for making garlands; leaves used, alone or mixed with other material as a compost or fertiliser for babai and other plants; leaves used to parcel food, as plates and to cover the earthen oven.

Recorded: CRL 1964; MCG 1979-1982; RRT 1996, 2006; AT 2008, 2009, 2011

Voucher Photographs: DPKR0124, 0125, 0180a, 0184, 0685, 0765, 0791a, 1909, 2424, 2425, 2477; AT20080430_09, AT20080430_10

Hedyotis romanzoffiensis (C \& S.) Fosb.

Synonym: Kadua romanzoffiensis Chamisso \& Schlechtendal

Status: Indigenous. A regional endemic reported from Tuvalu, Tokelau, the Northern Cook Islands, Tupa'i and Scilly in the Society Islands, the Tuamotu and Austral Islands and the Line Islands.

Abundance: Common.

Remarks: Although the Erithalis polygama (a synonym of Timonius uniflorus (Banks ex C.F.Gaertn.) Govaerts) reported from Cook Island by Bennett (1840) was most likely this species, it was first certainly recorded in 1924, when abundant in the south of the island near Paris and on the Southeast Peninsula, rare in the north. Most early records were in the vicinity of ponds and lagoons in the southeast, but at Joe's Hill in the 1930s, and at Manulu Lagoon and on Motu Tabu in the 1930s and 1960s (Fosberg and CRL specimens [AT!] at BISH). In 1965, reported as "much less abundant" than in 1927 (Jenkin and Foale, 1968). In the 1980s, common along the south coast except on the southeast peninsula, scattered in the interior between lagoons, and with occasional records on the Paris peninsula and on the north coast near the airport (MCG map). Not seen in 1996 and 2006, but in 2008-2009 found scattered over an extensive area of limestone hardpan and gravel along the southwest coast, in association with Lepidium bidentatum, as found in 1982 (RWH specimen labels). Scattered plants were found on the Paris peninsula in 2011. Not 
seen recently in the lagoon areas.

Recorded: FDB 1835; C\&B 1924; SFC 1934; F\&M 1936; LWB 1945; CRL 1964; RNJ 1965; MCG

1979-1982; RWH 1982, specimens[AT!] at BISH; LLW 1982; AT 2008, 2009, 2011

Voucher Photographs: AT20080426_61, AT20080426_62, AT20090919_01, AT20090919_04

Ixora casei Hance

Common Names: Flame of the forest, Case's ixora, Caroline Island ixora

Kiribati Names: te kaituru, te katuru

Status: Recent introduction. Caroline Islands (Micronesia).

Abundance: Uncommon, except in London, where it is a commonly planted ornamental in household gardens. Also in Tabwakea and Banana.

Remarks: Introduced to Kiritimati from elsewhere in Kiribati, where it is a common ornamental bush with scarlet flowers, having possibly been taken there from Pohnpei or another Micronesian island where it is endemic. Flowers used in garlands.

Recorded: RRT 1996, 2006; AT 2008

Voucher Photograph: DPKR0181

\section{Morinda citrifolia L.}

Common Names: Beach mulberry, Indian mulberry, noni, yaw bush

Kiribati Name: te non

Status: Recent introduction. Tropical Asia and Australia to southeast Polynesia.

Abundance: Common.

Remarks: First reported in the 1970s. Now planted or protected in household gardens in all settlements and around government buildings and tourist accomodation. Also seen around pigpens and common among hedge or border plantings. Young leaves cooked as a vegetable. Wood used to build houses, especially roofs; inner parts of roots mixed with ash and boiled to yield a red dye used to color mats, hats, fans, etc.; small leaves used to treat measles; ripe and unripe fruit used to relieve coughing, boiled ripe fruit eaten as an elixer, usually by old people, over-ripe fruit squashed and applied to warts; juice from the leaves used to treat boils. A large-fruited variety, reputedly from the Solomon Islands, was introduced during the European Community Pacific Regional Agricultural Project (PRAP) in the 1990s. Both varieties were common in London in 2008 and thereafter.

Recorded: RP 1977-1979; MCG 1979-1982; LLW 1982; RRT 1996, 2006; AT 2008, 2009, 2011, 2012

Voucher Photographs: DPKR0167, 0216, 0807, 1293b, 1660, 2302, 2307; AT20080427_03

Oldenlandia corymbosa L.

Synonym: Hedyotis corymbosa (L.) Lam.

Common Name: Old World diamondflower

Status: Recent introduction. Africa, now pantropical.

Abundance: Rare.

Remarks: Roadside weed seen along the edge of a houseyard garden in London in 2006 and at the airport in 2011.

Recorded: RRT 2006; AT 2011

Voucher Specimen: AT X001

Voucher Photographs: DPKR1277, 1278, 1279, 1286; AT20110309_03, AT20110309_04

Spermacoce assurgens Ruiz \& Pavón

Common Name: Buttonweed

Status: Recent introduction; accidental. Tropical America.

Abundance: Occasional.

Remarks: Only recorded in 2008, when fairly common in waste places in London, neighboring villages, 
the Agricultural Station and the airport, in April (rainy period); not found in 2009-2012 (drier weather during visits).

Recorded: AT 2008

Voucher Photographs: AT20080428_26, AT20080428_27

\section{RUTACEAE (RUE FAMILY)}

Citrus aurantiifolia (Christm.) Swingle

Common Name: Lime

Kiribati Name: te raim ("lime")

Status: Recent introduction. India.

Abundance: Rare. Planted fruit tree in a houseyard garden in London in 1996, and at the Main Camp

Store in 2006. The only citrus species which seems to do well in an atoll environment.

Recorded: RRT 1996, 2006

Voucher Photographs: DPKR1315b, 1316, 1317, 1318

\section{SOLANACEAE (NIGHTSHADE FAMILY)}

Capsicum annuum L. vars.

Common Name: Annual chili pepper

Kiribati Name: te beneka ("vinegar")

Status: Recent introduction. Tropical America.

Abundance: Occasional. Food plant cultivated in food gardens in London and Tabwakea in 1996 and in all settlements in 2006; commonly planted in 50-gallon drums and containers. In cultivation at the Agricultural Station in 2011. For LLW's record of "C. annuum" see under C. frutescens.

Recorded: RRT 1996, 2006; AT 2011

Voucher Photographs: DPKR0228, 0229, 0300, 0753, 0800, 1158, 1217, 1889a; AT20110309_03

Capsicum annuum L. var. grossum (L.) Sendtn.

Synonym: Capsicum grossum L.

Common Names: Bell pepper, sweet pepper, sweet capsicum

Kiribati Name: te boro, te beba

Status: Recent introduction. Tropical America.

Abundance: Occasional.

Remarks: Seasonal food plant seen in one houseyard food garden in London 1996, in a number of food gardens in 2006, and at the Agricultural Station in 2008.

Recorded: RRT 1996, 2006; AT 2008

Voucher Photographs: DPKR0753, 1160

\section{Capsicum frutescens L.}

Common Names: Tabasco, bird chili, perennial chili

Kiribati Name: te beneka ('vinegar")

Status: Recent introduction. Tropical America.

Abundance: Rare.

Remarks: First noticed about 1980. Planted spice plant seen in one garden in Tabwakea 1996, but not found since. "C. annuum" was reported as observed (but not collected) in 1982 (LLW) but, given recent changes in taxonomy of the genus, it is not now clear to which Capsicum species this record refers. Since MCG found C. frutescens about the same time, we place LLW's record here.

Recorded: MCG 1979-1982; LLW 1982 (?); RRT 1996 


\section{Nicotiana tabacum L.}

Common Name: Tobacco

Kiribati Name: te kai bake (“'baccy plant”)

Status: Recent introduction. Central and South America and the West Indies.

Abundance: Occasional.

Remarks: Seen in 1982, and in Poland village in 1996. In 2006 seen in only one garden in London, but common and planted in many gardens in Poland and almost adventive in some gardens. Uncommon adventive and garden plant in Tabwakea in 2009. Reported by older informants to have been much more common in the past. At least formerly, leaves were cured locally and smoked in rolled dried pandanus leaves or newspaper, but now largely treated as a garden ornamental or ignored.

Recorded: LLW 1982; RRT 1996, 2006; AT 2009

Voucher Photographs: DPKR0829, 0830, 0831, 0832, 1888, 1890, 1892, 1893, 1894b, 1895; AT20090922 04

\section{Physalis angulata L.}

Synonym: Physalis minima L. (of Wester, 1985)

Common Name: Cape gooseberry, bladderberry, ground cherry

Kiribati Name: te bin ("bean") (N. Gilbert Islands); te baraki (S. Gilbert Islands), te mato

Status: Recent introduction. Tropical and subtropical America.

Abundance: Common.

Remarks: First reported from a disturbed area at the airport in 1982, as a volunteer. Now a weed of houseyard and vegetable gardens, government building gardens, roadsides, waste places and ruderal sites in all settled areas including Poland, and near the airport.

Recorded: LLW 1982, Wester specimen 2149[AT!] at BISH; RRT 1996, 2006; AT 2009

Voucher Specimen: AT X016 Poland

Voucher Photographs: DPKR0048, 0157, 0247, 0677, 2325, 2327b

Solanum lycopersicum L.

Synonym: Lycopersicon esculentum Mill.

Common Name: Tomato

Kiribati Name: te tomato

Status: Recent introduction. Tropical America.

Abundance: Occasional.

Remarks: First reported in 1962 ("4 cultivated tomato plants near the airport"); seen growing wild near the port in 1965, and occasionally as a volunteer in waste areas in 1982. Now an occasional food plant in houseyard gardens in London, Tennessee, Tabwakea, Banana and Poland, and at the Agricultural Station. Seen as a volunteer plant on waste ground near stockpiled salvaged iron and equipment near the main pier in 2006.

Recorded: DCH 1962; CRL 1964; RNJ 1965; MCG 1979-1982; LLW 1982; RRT 1996, 2006; AT 2008, 2011, 2012

Voucher Photographs: DPKR0062, 0751, 0833, 1155, 1164c, 1188

\section{Solanum melongena L.}

Common Name: Eggplant, aubergine

Kiribati Name: te baigani

Status: Recent introduction. S. Asia.

Abundance: Occasional.

Remarks: Food plant in houseyard vegetable gardens in London, Tennessee, Tabwakea and Banana, in 1996 and 2006. In 2009 one plant at the Agricultural Station. 
Recorded: RRT 1996, 2006; AT 2009

Voucher Photographs: DPKR0821, 0823, 0824, 0836, 2019; AT20090922_41, AT20090922_42

\section{STERCULIACEAE (COCOA FAMILY)}

\section{Waltheria indica L.}

Common Name: Sleepy morning

Status: Recent introduction. Originally Americas, now a pantropical weed.

Abundance: Rare, probably extirpated.

Remarks: One record in the late 1970s of a few ornamental shrubs at the ruins of Rougier's house at Paris

(R. Perry, in litt.). Not found since, and only two species that were remnants of cultivation

(Leucaena leucocephala and Hibiscus tiliaceus) could be found at the ruins in 2011.

Recorded: RP 1977-1979

\section{SURIANACEAE (SURIANA FAMILY)}

\section{Suriana maritima L.}

Common Name: Bay cedar

Kiribati Name: te aroua

Status: Indigenous. Pantropical.

Abundance: Very abundant throughout the island (MCG map).

Remarks: The dominant species in the littoral vegetation on sandy and saline soils and saltflats and hardpans in most sites on the inner lagoon and in extensive areas of the hypersaline ponds, on rocky and hardpan areas near the lagoon coast and inland on poor, rocky or shell-rich soils. Also dominant in places near London, near hypersaline ponds inland from Main Camp, the inner lagoon near Y Site and the Ngaon te Taake Conservation Area, along St Stanislas Bay, and on the Paris peninsula. Abundant on both Motu Upua and Motu Tabu just inland from the littoral fringe on beaches and in drier sites on hardpans, such as on the northwest coast of Motu Upua where it dominates shrublands, often with scattered Tournefortia argentea. Uncommon on Cook Island, which has no hardpan areas, where represented by only a few plants along the beach on the far southwest coast. Also seen in pig rearing areas near London. The main species serving as a rookery and resting place for frigate birds (Fregata spp.) on Ngaon te Taake.

Recorded: THS 1874; C\&B 1924; GPW 1924; SFC 1934; F\&M 1936; LWB 1945; MDG 1958-1959; DCH 1962; CRL 1964; WAS 1965; RNJ 1965; RP 1977-1979; MCG 1979-1982; LLW 1982; RRT 1996, 2006; HLJ 1997; AT 2008, 2009, 2011, 2012

Voucher Photographs: DPKR0293, 0294, 0379, 0381a, 0385, 0393, 0618b, 0940, 1537, 1690a, 1691, 1694, 1696, 1700b, 1729, 1761a, 1948, 1953, 2089, 2095a, 2142a, 2191a, 2198a, 2214a, 2231; AT20080423_11, AT20080423_26

\section{TILIACEAE (LiNDEN FAMILY)}

\section{Triumfetta procumbens Forst. f.}

Common Name: Prostrate beach burr

Kiribati Name: te kiaou

Status: Recent introduction. Paleotropics including the Indo-Pacific region but probably a recent introduction to Kiritimati.

Abundance: Rare.

Remarks: Seen planted in a houseyard garden at Banana in 2006. In 2008, seen only at the Agricultural Station, growing in planting bags, where it was unclear whether it was an accidental weed or cultivated. In 2009 found only in one place, by the main road in Banana (same site as in 2006). Leaves used in garlands and in compost for babai. One of Kiribati's most important medicinal 
plants: leaves used medicinally, after boiling and applied to swollen limbs as a treatment for stonefish stings; leaves and stem tips boiled in water for a few hours used as a medicine with many applications, such as a disinfectant for bath water for babies, to reduce labor pains, to treat rashes and prickly heat; leaves mixed with coconut oil applied to septic cuts and sores; leaves boiled with toddy to clarify it; plant used in love magic and to treat diseeases due to te anti (ghosts and spirits).

Recorded: RRT 2006; AT 2008, 2009

Voucher Photographs: DPKR1201, 1202, 1203, 1204; AT20080428_08, AT20090922_34

\section{TURNERACEAE (TURNERA FAMILY)}

\section{Turnera ulmifolia L.}

Common Names: Yellow alder, sage rose, Marilopez, West Indian holly

Kiribati Name: te kakai nea ("the teaser")

Status: Recent introduction. Mexico and the Caribbean to northern South America.

Abundance: Common.

Remarks: First recorded in 2006. Now commonly planted as an ornamental in household gardens in all settlements, and by 2008-2009 had become quite commonly naturalized in waste places in London and Poland. In 2012 had spread further, with scattered plants along the main road between London and Tabwakea, around the Main Camp area including at the rubbish dump behind the JMB Store. It was introduced to Tarawa (Gilbert Islands) after 1993, probably from Nauru where it was a common ornamental by the mid-1990s; now spreading rapidly throughout Tarawa and on Abaiang and Abemama (RRT, pers. obs.). Bright yellow flowers used in garlands.

Recorded: RRT 2006; AT 2008, 2009, 2011, 2012

Voucher Photographs: DPKR0146b, 0265, 0266, 1300, 1902, 2303b, 2308, 2321, 2404, 2476; AT20080424 01

\section{VERBENACEAE (VERBENA FAMILY)}

Clerodendrum inerme L.

Common Name: Beach privet

Kiribati Name: te inato, te inoto

Status: Indigenous to the region but probably a recent introduction to Kiritimati. Indomalaysia, Australia and the Pacific islands.

Abundance: Occasional.

Remarks: First noticed about 1980. Seen in household gardens near Main Camp and in Tabwakea and London in 1996, and in most settlements in 2006-2012. Often planted as a hedge or border. Reported by locals to have been introduced to Kiritimati from wetter atolls in the Line Islands. There seem to be two varieties, one with smaller, darker green leaves and another with larger, lighter green leaves, similar to plants seen in the Gilbert Islands. Leaves mixed with coconut cream applied to open sores; used in treating prickly heat (te nimariri); used as a hair dye, to darken hair; leaves and flowers used in garlands.

Recorded: MCG 1979-1982; RRT 1996, 2006; AT 2008, 2009, 2011, 2012

Voucher Specimen: AT X027 London

Voucher Photographs: DPKR0132, 0133, 0135, 0297, 0318, 0732, 1990

Lantana camara L.

Common Name: Lantana

Kiribati Name: te kai boia

Status: Recent introduction. Tropical America.

Abundance: Common. 
Remarks: Planted ornamental, first recorded about 1980, although present at the church ruins at Main Camp in 2011, suggesting that it was used as a cultivated ornamental from the 1950s. Only occasional in 1996, but by 2008 commonly planted in all settlements. A serious invasive in many parts of the tropics but not reported as naturalized in Kiritimati until 2009, when found apparently growing wild and spreading in waste places near the wharf in London. Flowers used in garlands; flowers said to be used by some people to treat infantile diarrhoea. Poisonous, although children are said to eat the fruits.

Recorded: MCG 1979-1982; RRT 1996, 2006, AT 2008, 2009, 2011, 2012

Voucher Photographs: DPKR02024, 0313, 0314, 0763, 1251, 1252, 1630, 1889, 2456; AT20080426_02, AT20090918_02, AT20090918_04

\section{Premna serratifolia L.}

Common Name: False elderberry, premna

Kiribati Name: te ango

Status: Indigenous to the region but probably a recent introduction to Kiritimati. Indopacific.

Abundance: Occasional.

Remarks: Not reported before 1996, and so far seen only where probably planted. Tree in houseyard gardens and occasionally along roadsides, in London, Tabwakea and Banana; also planted at the Captain Cook Hotel. Wood used in house construction and formerly to make fire by friction; straight sprouts and limbs used for fishing poles; roots used to perfume coconut oil; leaves used to treat sinusitis, as poultices for painful limbs; finely cut leaves boiled to treat post-partum haemmorhage.

Recorded: RRT 1996, 2006; AT 2009, 2012

Voucher Specimen: AT X017 Captain Cook Hotel

Voucher Photographs: DPKR0217, 0218, 2376, 2377, 2441, 2442, 2443, 2480; AT20090922_16, AT20090922_17, AT20090922_18

\section{ZYGOPHYLLACEAE (CALTROP FAMILY)}

Tribulus cistoides L.

Common Names: Goat head, puncture vine, caltrops

Kiribati name: te maukinikin

Status: Probably a recent introduction to Kiritimati although perhaps indigenous to the region. Origin uncertain but now pantropical, and widespread in Polynesia and Micronesia including the Gilbert, Phoenix and Line Islands. Abundant. Creeping herb with thorny fruit, in 1924 found only in the northwest, scattered among Lepturus and Sida fallax in dry areas. In 1965 found mainly near Poland and at the base of the Paris peninsula. Common and widespread by the late 1970s, when found throughout the northwest, near the airport, around Poland and Dakota Strip, and scattered through the central lagoon area, including on many lagoon islets (MCG map). Today, is still most common and sometimes dominant in waste places and ruderal sites throughout the island, in villages, old military sites and other sites where spread by people, even in the southeast (e.g., near Dakota Strip and along roads and tracks). Not found in 1997 or 2010-2011 around the ruins of the old South Pacific Airways Hotel on the Paris peninsula. Particularly common on open sandy ground, including some sites away from human habitation, such as in some open herblands and on the bird islands of Motu Upua, Motu Tabu and Cook Island, but uncommon on Ngaon te Taake Islet. Remains common even after dry periods when most ruderals disappear, such as in early 2011. In March 2012, after one month of rainy weather, carpeted large areas between London and Tabwakea, and elsewhere. Possibly still spreading rapidly; known as highly invasive in other parts of the tropics.

Recorded: C\&B 1924; FLH 1957; MDG 1958-1959; DCH 1962; RNJ 1965; RP 1977-1979; MCG 19791982; LLW 1982; RRT 1996, 2006; HLJ 1997; AT 2008, 2009, 2011, 2012 
Voucher Specimen: AT X045 north of London

Voucher Photographs: DPKR0028, 0030, 0031, 0338, 0553b, 0555b, 0687, 0743a, 0929, 0963, 1420a, 1500, 1975; AT20080426_52, AT20080426_53

\section{ACKNOWLEDGMENTS}

We thank the many people and organizations that have facilitated our studies on the flora of Kiritimati, including the Secretariat of the Pacific Environment Programme (SPREP), which sponsored RRT's visit in 1996 to study the island as a potential site for the South Pacific Biodiversity Conservation Programme (SPBCP) and AT's visits as part of SPREP's support to Kiribati's invasive species management activities. We also thank The University of the South Pacific for its support over the years and The Total Enterprise Coral Reef Foundation for their support of a marine conservation biodiversity research grant in the 2000s. People who have played central roles in facilitating our research include RRT's co-authors of the Kiritimati Island Biodiversity Conservation Area study in 1996 (Thaman et al., 1997), Robert Tuxson and Bwere Eritaia, and others who assisted in the project, including Kim Anderson, Miire Awira, Tonga Fou, Marutaake Karawaiti, Iotam Kirata, Aren Teannaki, Erua Tekaraba, Tarataake Teannaki, Aobure Teatata, Katino Teebaki, Kararaua Tonana, Kata Totie and David Yee Ting. We also thank fellow team members of the USP visit in 2006, Leon Zann, Ed Lovell and Aaron Jenkins, and Manate Tenang, Ereti Tekabwaia and her late father, Tekabwaia. We also thank the people who assisted AT on his recent visits and subsequent analyses. These include Martin Garnett, Bob Hobdy, Lee Jones, Roger Perry and Lyndon Wester, who kindly provided much useful information and documents concerning their own records from the 1970s, 1980s and 1990s. Miraneta Williams-Hazelman at the SPREP Information Resource Centre, Kim Anderson on Kiritimati, Paul Jones and Angela K. Kepler provided copies of some additional key documents. Barbara Kennedy (Bishop Museum), Fred Stauffer (Conservatoire et Jardin Botanique, Geneva), Marie Briggs, Alan Paton and Kiri Ross-Jones (Royal Botanic Gardens, Kew), and Robert Vogt (Botanischer Garten und Botanisches Museum Berlin-Dahlem) kindly provided information on specimens at $\mathrm{BISH}, \mathrm{G}, \mathrm{K}$ and B respectively, and on their collectors. We thank Norman A. Douglas, Anne Guézou, Tom Koyama and Neil Snow for discussion of the systematics and identification of Boerhavia, Amaranthus, Cyperaceae and Poaceae respectively. Our friends and colleagues on Kiritimati Island, including Uriam Anterea, Ratita Bebe, Aana Berenti, the late Bio Eberi, the late Ibeatabu Katabanin, Katareti Taabu and Aobure Teatata (Wildlife Conservation Unit), Ereti Tekabwaia (London), and Nautonga Anterea, Aata Binoka and Mamarau Kairirieta (Agricultural Division), as well as Nenenteiti Teariki-Ruatu (Environment and Conservation Division) in Tarawa, provided much information, assistance, transport and good company during AT's visits to their island. Many other people on Kiritimati have assisted us in many ways and we apologize for not being able to acknowledge everyone by name. 


\section{APPENDIX: \\ PLANT RECORDERS AND COLLECTORS ON KIRITIMATI ATOLL}

The following is a chronological listing of plant recorders and collectors on Kiritimati Atoll from 1777 to 2012. Dates refer to the periods when the collections or observations were made. Herbarium abbreviations follow Index Herbariorum usage (http://sciweb.nybg.org/science2/IndexHerbariorum.asp).

Cook 1777 Captain James Cook discovered the island for European science on 24 December 1777, and over the next few days recorded coconuts and the planting by his crew of some nonnative food plants, as reported in Cook (1784).

FDB 1835 Frederick Debell Bennett was the surgeon on board the whaling ship Tuscan, which circumnavigated the globe between 1833 and 1836. He stopped on Christmas Island 6-10 May 1835, made plant collections there, and mentioned nine species in his account of the voyage (Bennett, 1840), most of them first records for the island. Many (approximately 743) of his specimens from the voyage were sent to the "Berlin Herbarium," now the Botanischer Garten und Botanisches Museum Berlin-Dahlem, Zentraleinrichtung der Freien Universität Berlin (B), and more (2060 specimens) were later acquired by B when they purchased, in 1842, the A. B. Lambert herbarium. About $90 \%$ of the Bennett specimens at B were destroyed in 1943, during the WWII (R. Vogt, pers. comm.), including most or perhaps all of the Kiritimati collections. Wester (1985) suggested that some duplicates might exist at the British Museum (BM) or at Kew (K), and indeed $\mathrm{K}$ does hold some Bennett specimens from the voyage, but they are not all catalogued and it is not known whether they include any Kiritimati specimens. Wester (1985) did not list Bennett's plant records.

THS 1874 Thomas H. Streets and William H Jones visited 14-22 January 1874 while on the United States North Pacific Surveying Expedition. Some of their specimens are in the U.S. National Herbarium (US), and a list was published by Streets (1877).

C\&B 1924 Erling Christopherson and H. F. Bergman, 31 July to 7 August 1924, while botanists on the Bishop Museum Whippoorwill Expedition to the Line Islands. Both collected on Kiritimati although most collections were by Bergmann. Their specimens are at the Bishop Museum (BISH) and US, and were reported by Christophersen (1927).

GPW 1924 Gerrit P. Wilder, 8-17 December 1924 (the date "1923" in Wester 1985 is a typographic error), while on the "Cruise of the Kamiloa." Specimens held by BISH.

SFC 1934 Harold St. John, F. Raymond Fosberg and Charles Montague Cooke Jr., 21-22 October 1934, on return from the Bishop Museum's Mangarevan Expedition. Specimens at BISH and US.

EHB

1935-1938 E. H. Bryan, curator at the Bishop Museum, made some plant observations on Kiritimati, which are mentioned in Bryan (1942), but he made no collections there.

F\&M 1936 F. Raymond Fosberg and Alfred Metraux, 16 August 1936. Specimens held by BISH and US; some new records were published by Fosberg (1943).

LWB 1945 L. William Bryan, Territorial Forester in the Board of Agriculture and Forestry on the island of Hawai'i, collected on Kiritimati in October 1945. Specimens at BISH, but we have found no other information about his visit. Not mentioned by Wester (1985).

WFC 1957 Captain W. F. Curlett of the Royal Engineers sent specimens collected on Kiritimati in June 1957 to K. Two specimens reported in Wester (1985).

FLH 1957 F. L. Hill collected on Kiritimati on 25 October and 10 November 1957. Specimens held at BISH and reported by Wester (1985). No other information was found about his visit.

JPG 1958 Corporal J. P. Griggs of the Royal Engineers sent eight specimens from Kiritimati to K in 1958. Three of these were reported by Wester (1985). 
MDG

$1958-1959$

DCH 1962

CRL

1964, 1965 C. R. Long collected during two voyages as part of the Pacific Ocean Biological Survey, the goal of which was an inventory of the terrestrial flora of the atolls of the Central Pacific. During the first voyage he stopped at Kiritimati twice, 14-16 June and 21-23 November 1964, and then on the next voyage on 25-30 June 1965. Specimens and notes at BISH, and some specimens at US.

WAS 1965 W. A. Sledge of the University of Leeds collected at least eight specimens on Kiritimati 19-20 April 1965, which are at K. We found no other information on his visit, except that he also collected on Teraina and Tabuaeran. Six of his Kiritimati specimens reported in Wester (1985).

RNJ 1965 R. N. Jenkin collected in August-September 1965 while conducting a British Directorate of Overseas Surveys study of the potential for growing coconuts on the island. Specimens held at K. The plants are discussed in Jenkin and Foale (1968).

RP

$1977-1979$

MCG

1979-1982

RWH 1982

LLW 1982

RRT 1996

HLJ 1997

RRT 2006
Roger Perry was resident on Kiritimati from 1977 to 1979, where he set up the Wildlife Conservation Unit in preparation for the independence of Kiribati. His specimens are in K, dated August 1979, but this is the accession date rather than collection date (Perry, 1979).

Martin C. Garnett was resident on the island from May 1979 to September 1982, managing the Wildlife Conservation Unit and carrying out survey work in the Line and Phoenix islands in preparation for writing management plans for each island (Garnett, 1983). The management plans contain plant information and distribution maps in Volume 1. Not mentioned by Wester (1985).

Robert W. Hobdy, Forestry Manager, Maui District (Hawaii), during a one-week holiday on Kiritimati in January 1982, collected 13 specimens, which are at BISH. Not mentioned by Wester (1985).

Lyndon L. Wester made plant observations and collections on Kiritimati 12-19 August 1982 while conducting vegetation surveys in the Northern Line Islands. Specimens held at BISH and reported in Wester (1985)

Randolph R. Thaman collected and inventoried the flora on 4-9 July 1996 while carrying out a study to designate parts of Kiritimati as a conservation area under the South Pacific Biodiversity Conservation Programme of the Secretariat of the Pacific Regional Environment Programme (SPREP). Specimens held in the South Pacific Regional Herbarium (SUVA) at the University of the South Pacific (USP), Fiji.

H. Lee Jones carried out plant surveys during the period 3-20 May 1997, as part of the environmental impact studies for a proposed Japanese spacecraft landing site. His observations were included in the project report (Jones, 1997).

Randolph R. Thaman inventoried, collected and digitally photographed plants and vegetation on a USP expedition from 31 May to 7 June 2006. Specimens held at SUVA. 
AT 2008, 2009,

2011,2012 Alan Tye of SPREP collected and made plant observations and photographs during four visits to Kiritimati totaling five weeks on the island, 23-30 April 2008, 16-23 September 2009, 2-9 March 2011 and 14-28 March 2012, while assisting the Wildlife Conservation Unit to plan and carry out conservation work. Specimens held at SUVA. 


\section{REFERENCES}

Benson, G. 1838. Sketch of Christmas Island, with a Chart of the Island. Hawaiian Spectator, 1:64-68.

Bennett, F. D. 1840. Narrative of a Whaling Voyage Round the Globe from the Year 1833 to 1836. 2 vols. London: Richard Bentley. [Facsimile edition published 1970, Amsterdam: N. Israel; New York: Da Capo.]

Bryan, E. H., Jr. 1942. American Polynesia and the Hawaiian Chain. Honolulu: Tongg. 1953. Checklist of Atolls. Atoll Research Bulletin, 19:1-38. 1972. Life in the Marshall Islands. Honolulu: Pacific Science Information Center, B. P. Bishop Museum.

Carter, J., ed. 1984. Pacific Islands Yearbook. 15th ed. Syndey: Pacific Publications.

Catala, R. L. A. 1957. Report on the Gilbert Islands: Some Aspects of Human Ecology. Atoll Research Bulletin, 59:1-187.

Chock, A. K., and D. C. Hamilton. 1962. Plants of Christmas Island. Atoll Research Bulletin, 90:1-7.

Christophersen, E. 1927. Vegetation of Pacific Equatorial Islands. B. P. Bishop Museum Bulletin, 44:179.

Clayton, W. D., and N. Snow. 2010. A Key to Pacific Grasses. Kew, UK: Royal Botanic Gardens.

Cook, J. 1784. A Voyage to the Pacific Ocean ...Under the Direction of Captains Cook, Clerke, and Gore (1776-1780). London: Strahan \& Cadell.

Emory, K. P. 1934 Archaeology of the Pacific Equatorial Islands. B. P. Bishop Museum Bulletin, 123:143.

Falkland, T., and I. White. 2007. Kiribati. Preparing the Outer Island Growth Centers Project — Phase 2 (Water Supply and Sanitation). Working Papers (Volume 2). Working Paper No 1: Hydrology. Melbourne: Sinclair Knight Merz.

Fosberg, F. R. 1943. Notes on Plants of the Pacific Islands-III. Bull. Torrey Bot. Club, 70:386-397. . 1978. Studies in the Genus Boerhavia L. (Nyctaginaceae), 1-5. Smithsonian Contributions to Botany, No. 39. Washington, D.C.: Smithsonian Institution Press. 1988. New and Noteworthy Plants from Great Barrier Reef Sand Cays, Australia. Brittonia, 40:52-65.

[Gallagher, M. D.] 1959. Vegetation on Christmas Island. Natural History Society, Christmas Island, Bulletin, 6:E3-E6. [Compiled and produced by Natural History Society, Christmas Island.]

Gardner, R. 2007. Grasses (Gramineae) of the Central Pacific Ocean Region. Records of the Auckland Museum, 44:43-83.

Garnett, M. C. 1983. "A Management Plan for Nature Conservation in the Line and Phoenix Islands." Unpublished report to the Government of Kiribati and U.K. Overseas Development Administration.

Jenkin, R. N., and M. A. Foale. 1968. An Investigation of the Coconut Growing Potential of Christmas Island. 2 vols. Land Resource Study 4. Tolworth, UK: Directorate of Overseas Surveys, Land Resources Division.

Jones, H. L. 1997. "Christmas Island Hope-X Landing Site: Impact Assessment for Terrestrial Biota." Appendix A in Environmental Impact Assessment, Hope-X Landing Site Facilities, Kiritimati (Christmas) Island, Republic of Kiribati. Honolulu: Dames \& Moore.

Maude, H. E. 1968. Of Islands and Men. London: Oxford University Press.

Morrison, R. J. 1987. Chemistry and Classification of Pacific Low Atoll Soils. Alafua Agricultural Bulletin, 12(3):25-30.

Office of Te Beretitenti. 2012. Kiritimati. Republic of Kiribati Island Report Series 20. Tarawa: Office of Te Beretitenti.

Perry, R. 1981. Christmas Island. Pacific Discovery, 34(3):9-18.

Streets, T. H. 1877. Contributions to the Natural History of the Hawaiian and Fanning Islands and Lower California, Made in Connection with the United States North Pacific Surveying Expedition, 
1873-75. Bulletin of the United States National Museum, Vol. 1, Article 7. Washington, D.C.: Smithsonian Institution.

Teeb’aki, K. 1993. "Republic of Kiribati.” In A Directory of Wetlands in Oceania, ed. D. A. Scott. Slimbridge, UK: International Waterfowl and Wetlands Research Bureau.

Thaman, R. R. 2008. Atolls - The "Biodiversity Cool Spots" vs "Hot Spots": A Critical New Focus for Research and Conservation. Micronesica, 40:33-61.

Thaman, R. R., and R. W. Tuxson. 1997. "Environmental Guidelines for the Sustainable Development of Kiritimati Atoll, Republic of Kiribati: Preliminary Guidelines for the Environmental Impact Assessment of the Proposed NASDA Hope-X Landing Site.” Informational paper prepared at the request of the Ministry for Environment and Social Development, Republic of Kiribati. Suva: University of the South Pacific.

Thaman, R. R., R. Tuxson, and B. Eritaia. 1997. "Kiritimati Atoll Conservation Area: South Pacific Biodiversity Programme Project Preparation Document." Bikenibeu, Tarawa, Kiribati: Environment Unit, Ministry of Environment and Social Development.

Wester, L. 1985. Checklist of the Vascular Plants of the Northern Line Islands. Atoll Research Bulletin, 287:1-38.

Wiens, H. J. 1962. Atoll Environment and Ecology. New Haven, CT: Yale University Press. 